Universidade de São Paulo

Faculdade de Filosofia, Ciências e Letras de Ribeirão Preto Departamento de Química

Programa de Pós-Graduação em Química

Aprendizagem de conceitos químicos num curso EaD: contribuições da

Teoria da Atividade

JOÃO RICARDO SANCHEZ

Tese apresentada à Faculdade de Filosofia, Ciências e Letras de Ribeirão Preto da Universidade de São Paulo, como parte das exigências para a obtenção do título de Doutor em Ciências, Área: Química

Ribeirão Preto -SP 
Universidade de São Paulo

Faculdade de Filosofia, Ciências e Letras de Ribeirão Preto Departamento de Química

Programa de Pós-Graduação em Química

\title{
Aprendizagem de conceitos químicos num curso EaD: contribuições da
}

\section{Teoria da Atividade}

\author{
João Ricardo Sanchez \\ Orientadora: Profa. Dra. Daniela Gonçalves de Abreu \\ Co-orientadora: Profa. Dra. Joana de Jesus de Andrade
}

Tese apresentada à Faculdade de Filosofia, Ciências e Letras de Ribeirão Preto da Universidade de São Paulo, como parte das exigências para a obtenção do título de Doutor em Ciências, Área: Química

Versão corrigida da Tese de Doutorado apresentada ao Programa de Pós-Graduação em Química no dia 03/12/2018. A versão original encontra-se disponível na Faculdade de Filosofia, Ciências e Letras de Ribeirão Preto.

Ribeirão Preto -SP 
Autorizo a reprodução e divulgação total ou parcial deste trabalho, por qualquer meio convencional ou eletrônico, para fins de estudo e pesquisa, desde que citada a fonte.

\section{FICHA CATALOGRÁFICA}

Sanchez, João Ricardo.

Aprendizagem de conceitos químicos num curso EaD: contribuições da Teoria da

Atividade, 2018.

p.105 : Il. ; $30 \mathrm{~cm}$

Tese apresentada à Faculdade de Filosofia, Ciências e Letras de Ribeirão Preto/USP.

Área de concentração: Química.

Orientadora: Daniela Gonçalves de Abreu Favacho.

1.Química. 2. Educação a Distância. 3.Teoria da Atividade. 


\section{FOLHA DE APROVAÇÃO}

Nome: Sanchez, João Ricardo

Título: Aprendizagem de conceitos químicos num curso EaD: contribuições da Teoria da Atividade

Tese apresentada à Faculdade de Filosofia, Ciências e Letras de Ribeirão Preto da Universidade de São Paulo, como parte das exigências para a obtenção do título de Doutor em Ciências, Área: Química

Aprovado em:

Prof. Dr.

Instituição:

Assinatura:

Prof. Dr.

Instituição:

Assinatura:

Prof. Dr.

Instituição:

Assinatura: 
Prof. Dr.

Instituição:

Assinatura:

Prof. Dr.

Instituição:

Assinatura: 


\section{DEDICATÓRIA}

QDedico este trabalho a minha avó Maria Anngela,

que éuma fortaleza, exemplo de fé, sabedoria,

persistência e amor a vida.

Masso maior exemplo!

Obrigado por tudo. Otmo muito a senhora. 


\section{AGRADECIMENTOS}

A Deus pelas bênçãos diárias, pelo privilégio da vida e por todo o aprendizado inerente ao processo "de viver".

Aos meus pais Rosendo Maya Sanchez e Luzia Moreira Sanchez, meus maiores incentivadores. Obrigado por todo o cuidado, orientação, investimento e torcida! Amo muito vocês.

As minhas irmãs Kátia Cristina Sanchez e Kelly Cristina Sanchez, meus sobrinhos Sofia e Pedro, pelo cuidado, pela parceria, pelo nosso amor incondicional. Vocês são minha referência. Amo demais.

A toda a minha família, tios, tias, primos e aos agregados. Amo vocês.

A Thaís Peres Gonçalves, minha irmã de coração. Parceira de muitos anos e para toda a vida. Obrigado por todas as conversas, reflexões, aprendizados, risadas, diversões, tristezas e crescimento.

A professora Daniela Gonçalves de Abreu, minha orientadora desde o primeiro ano da Faculdade, orientadora acadêmica e pessoal. Parceria, amiga, profissional comprometida com a Educação e com o próximo. Exemplo ímpar de benignidade e humildade.

A professora Joana de Jesus de Andrade, minha co-orientadora e também grande amiga. Obrigado por todos os ensinamentos, pelas importantes contribuições e aprendizados. Obrigado por aceitar o desafio de desenvolver conosco esse trabalho.

A professora Yassuko Iamamoto, exemplo de profissional, de dedicação e de sensibilidade. Obrigado por compartilhar conosco um pouco de sua experiência e por acreditar no Ensino de Química

A Daniela Mica Espimpolo, outra irmã que a vida me deu. Obrigado por toda a cumplicidade, "amizade sem filtro", estudos, aprendizados, risadas e trabalhos compartilhados. Amo como se fosse da minha família.

Ao Isaltino Alves Barbosa, parceiro que sempre me auxiliou no desenvolvimento das atividades acadêmicas da pós-graduação e que se tornou um grande amigo, para além da Universidade. Obrigado pelas conversas e aprendizagens compartilhadas, por todo o incentivo e orientação. 
A Renata Bernardo Araújo, amiga, parceria, irmãzinha que a pós-graduação me deu. Obrigado pelos auxílios e cuidados nos momentos difíceis. Iniciamos juntos no mestrado e chegamos até aqui mais fortes, mais maduros e mais realizados.

A banca do exame de qualificação, professoras Elaine Araújo, Joana de Andrade e Vanessa Moretti, pela leitura do trabalho, contribuições e orientações.

Aos alunos e toda a equipe do curso de Licenciatura em Ciências (EaD) da USP.

Ao Fabrício Bortolucci Zanardi, amigo, parceiro de profissão e colega da pós-graduação. Por todo o auxílio e torcida.

A Débora Mourao Mantovanini, minha amiga, minha terapeuta, minha orientadora para todas as ocasiões. Obrigado por tudo!

Aos meus colegas e parceiros da Etec Angelo Cavalheiro (Serrana), por todo o incentivo e compreensão nos momentos de organização de trabalho e estudos.

A Universidade de São Paulo (USP) e a Universidade Virtual do Estado de São Paulo (UNIVESP), por todo o aprendizado proporcionado. 
"Viva de forma simples. Ame com generosidade. Fale verdadeiramente. Respire fundo. Faça o seu melhor sem se cobrar ou ter muita consciência disso. Deixe o resto para as forças acima de você. As pessoas podem ser muito boas no que fazem, até descobrirem o quão boas elas são". 


\section{RESUMO}

Com a expansão da Educação a Distância $(\mathrm{EaD})$, vários cursos tem sido oferecidos no formato digital, inclusive cursos superiores de Ciências. Em trabalhos anteriores, pautados na Teoria da Atividade de Leontiev, desenvolvemos Atividades Orientadoras de Ensino (AOEs) sobre identificaçãoseparação de metais pesados e investigamos a potencialidade destas como proposta teórico-metodológica em um Curso presencial de Licenciatura em Química. A formação presencial em Química do pesquisador e a atuação como tutor junto ao curso $\mathrm{EaD}$ em uma Universidade Paulista, favoreceram a definição da questão central neste trabalho: na $\mathrm{EaD}$, como essa atividade mobilizaria os estudantes em direção a aprendizagem do conhecimento químico?A fundamentação teórica deste trabalho baseia-se em trabalhos de Vigotski, Leontiev e Engeström. A pesquisa qualitativa foi a metodologia de pesquisa adotada, com destaque para a análise microgenética. O campo empírico foi o fórum de discussão virtual no qual as AEs foram disponibilizadas. Este fórum na forma de $\mathrm{AE}$ foi desenvolvido com alunos da $\mathrm{EaD}$ em 7 cidades do Estado de São Paulo. Ao planejar a $\mathrm{AE}$ a distância, concentramos em não valorizar situações práticas experimentais como no Ensino presencial, pois na situação virtual, o aluno estaria sozinho durante o desenvolvimento da atividade e sem muitos recursos laboratoriais. Pudemos notar que a interação aluno-aluno foi menor na atividade a distância, pois a maior parte da discussão ocorreu a partir da interação com pesquisador/mediador.Os resultados evidenciaram que nos 8 grupos em que a $\mathrm{AE}$ foi desenvolvida, surgiram diversas palavras relativas aos temas estudados, direta ou indiretamente, e que o sistema de análise realizado apontou para importantes processos de elaboração conceitual, uma vez que alguns conceitos foram estabelecidos, outros foram questionados e refutados. No ensino presencial a aplicação da AOE teria sido analisada em maior parte do ponto de vista de cada indivíduo e acreditamos que esta caracterização tenha sido mantida na EaD. Todavia, as informações ou experiências sócio-culturais se mostraram mais evidentes no formato $\mathrm{AE}$ a distância em detrimento da AOE presencial.

Palavras-chave: Química, Educação a Distância, Teoria da Atividade. 


\begin{abstract}
As the Distance Education (DE) becomes more popular many course are being offered in the on-line version, including Science degree courses. In previous papers, based on Leontiev's Activity Theory, we developed Teaching Guiding Activities (TGAs) about the indentification-separation of heavy metals and investigated the potential of these TGAs as a theoretical-methodological proposal in a face-to-face Chemistry Teaching course. The researcher's regular face-to-face Chemistry degree and his work as a monitor in the Distance Education course at São Paulo University helped defining this paper central question: in Distance Education, how would a TA engage students toward the learning of chemical knowledge ? The theoretical bases of this paper are the works developed by Vigotski, Leontiev and Engeström. The methodology used was the qualitative research, with focus on the Microgenetic Analysis. The empirical field was the on-line discussion forums, where the TAs were available. The TA/forum was developed with distance education students from 7 different cities in São Paulo State. When planning the TA-DE (TGA for the Distance Education), we focused on not having experimental practices as it is common in face-to-face courses because the student would be alone during the activity and would not have many laboratory resources. We could notice that in the distance activity the student-student interaction was not satisfactory as the participants would interact with the researcher/professor. The results made it evident that in the 8 groups, in which the TA was developed, several words appeared on the subjects studied, directly or indirectly, and that in the system of analysis carried out pointed to important processes of conceptual elaboration, some concepts were developed, some were questioned and/or refuted. At the face-to-face education the TA development would be analyzed mostly from the individual perspective and we believe that this characteristic was kept at the Distance Education. However, social-historical information or experiences were shown more during the development of the distance TA than in the face-to-face one.
\end{abstract}

Keywords: Chemistry, Distance Education, Activity Theory, 


\section{LISTA DE FIGURAS}

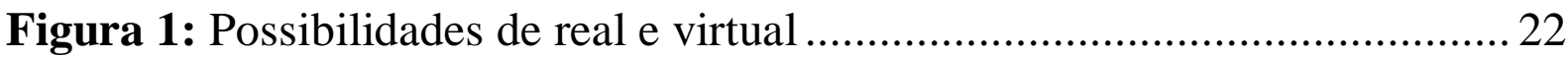

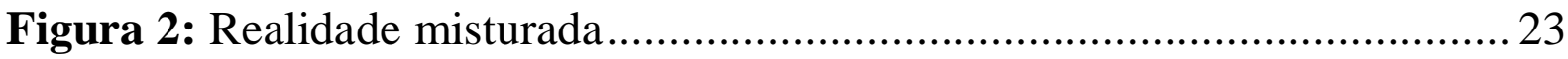

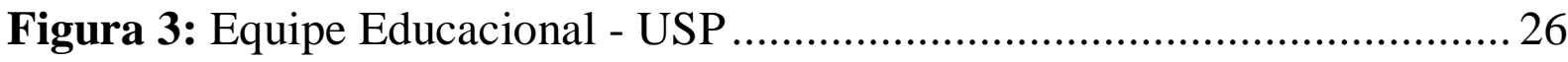

Figura 4: Equipe Educacional - Licenciaturas/UNIVESP ..................................30

Figura 5: Medidas da condutância da pele - Atividade eletrodérmica (EDA) .. 34

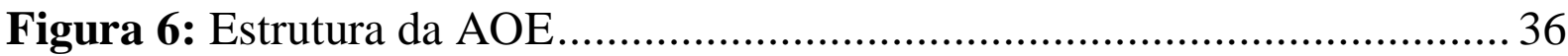

Figura 7: Uma tríade representação de ações................................................... 38

Figura 8: Um modelo complexo do sistema de atividade .............................. 39

Figura 9: Adaptação do modelo de Sistema de Atividade para EaD em Ciências

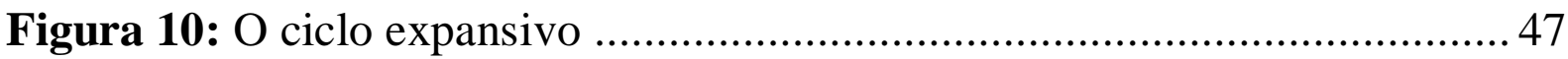

Figura 11: Possibilidade de movimentação ………………………….......... 71 


\section{LISTA DE SIGLAS}

AE: Atividade de Ensino.

AOE: Atividade Orientadora de Ensino.

AVA: Ambiente Virtual de Aprendizagem.

BDTD: Biblioteca Digital Brasileira de Teses e Dissertações.

BPL: Based Problem Learning.

CARPRE: Colégio Adventista de Ribeirão Preto.

CNE: Conselho Nacional de Educação.

DQ: Departamento de Química.

EaD: Educação a Distância.

EM: Ensino Médio.

ETIM: Ensino Técnico Integrado ao Médio.

FFCLRP: Faculdade de Filosofia, Ciências e Letras de Ribeirão Preto.

FURG: Universidade Federal do Rio Grande.

FUSP: Fundação de Apoio à Universidade de São Paulo.

FUVEST: Fundação Universitária para o Vestibular.

LDB: Lei de Diretrizes e Bases.

LC: Licenciatura em Ciências.

MAs: Metodologias Ativas.

MP: Metais Pesados.

PCC: Prática como Componente Curricular.

PHC: Psicologia Histórico-Cultural.

PPP: Projeto Político Pedagógico.

QAQ: Química Analítica Qualitativa.

SIBI: Sistema Integrado de Bibliotecas. 
TA: Teoria da Atividade.

TAC: Teoria da Atividade Criativa.

TDICs: Tecnologias Digitais de Informação e Comunicação.

TICs: Tecnologias da Informação e Comunicação.

TQ: Técnico em Química.

UAB: Universidade Aberta do Brasil.

UNAR: Centro Universitário de Araras Dr. Edmundo Ulson

UNIVESP: Universidade Virtual do Estado de São Paulo.

USP: Universidade de São Paulo. 


\section{LISTA DE QUADROS}

Quadro 1.Polos e número de alunos matriculados.

\section{LISTA DE TABELAS}

Tabela 1. Relação Oferta x Número de Concluintes 


\section{SUMÁRIO}

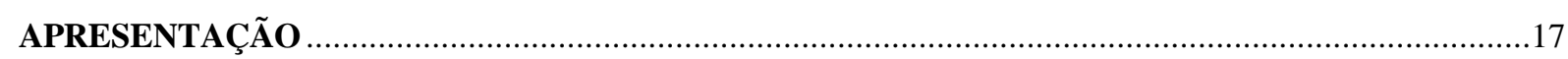

1. INTRODUÇÃO

1.1 - A EDUCAÇÃO A DISTÂNCIA ……........................................................... 19

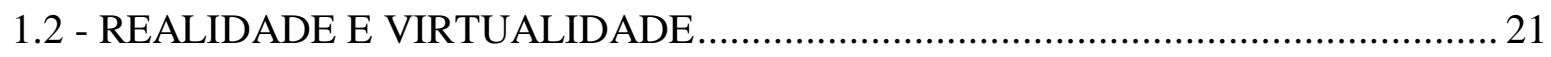

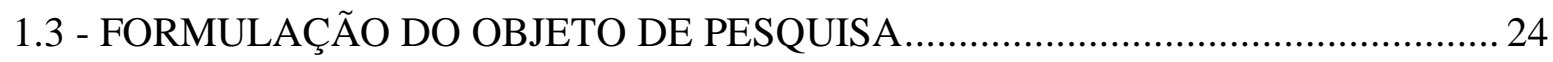

1.4 - LICENCIATURA EM CIÊNCIASNA MODALIDADE EAD................................. 25

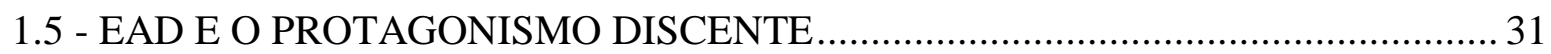

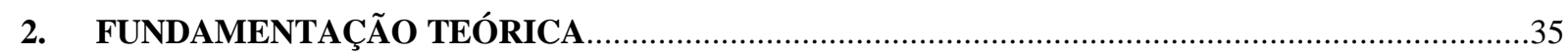

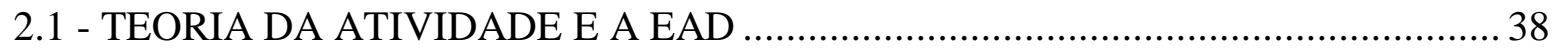

2.2 - TEORIA DA ATIVIDADE E A COMPUTAÇÃO ............................................. 43

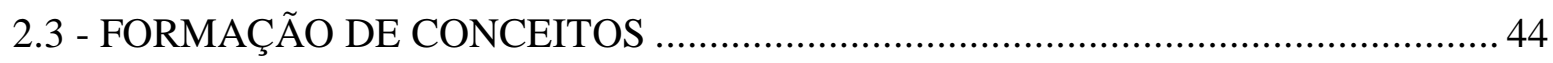

2.4 - CONCEITOS ESPONTÂNEOS E CONCEITOS CIENTÍFICOS (VIGOTSKI) ....... 49

2.5 - MEDIAÇÃO E O PROCESSO DE APRENDIZAGEM ..................................... 51

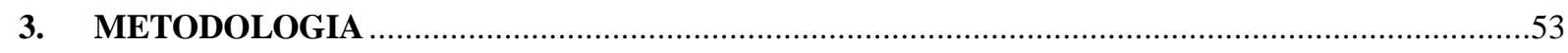

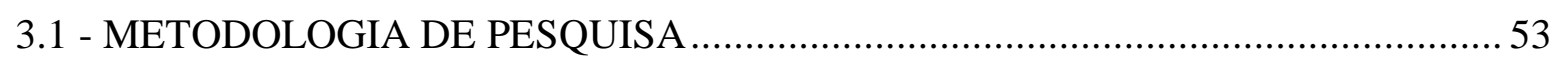

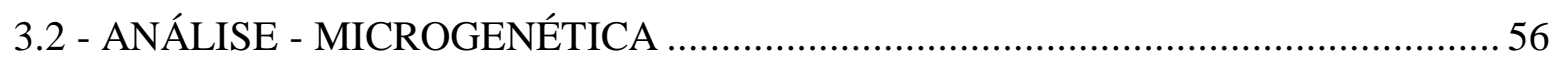

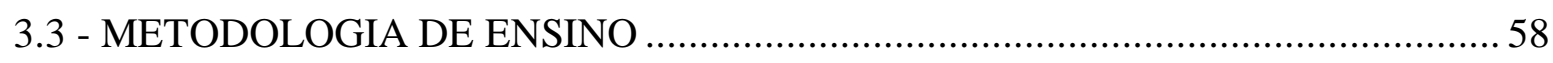

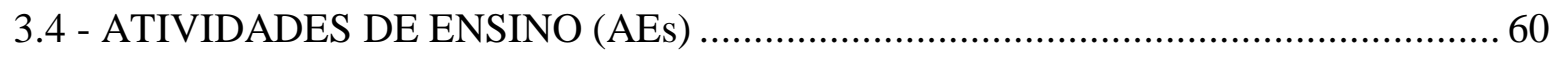

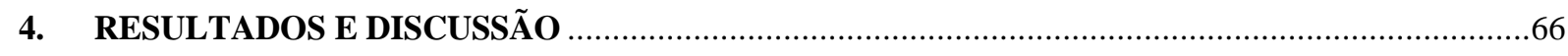

EPISÓDIO I: MEDIAÇÃO (DO TUTOR, DA LINGUAGEM, DO RECURSO).............. 66 EPISÓDIO I - PARTE A: AE-1:OBTENÇÃO DE SUBSTÂNCIAS - METAIS PESADOS (MP).

EPISÓDIO I - PARTE B: AE-2, CINÉTICA DAS REAÇÕES QUÍMICAS - PRAZO DE

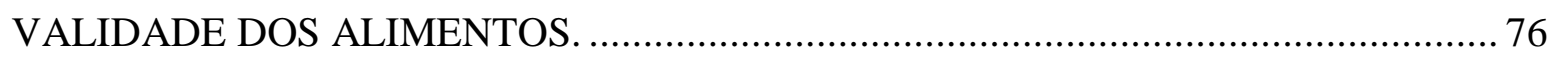

EPISÓDIO 2. MOBILIZAÇÃO DO ALUNO EM DIREÇÃO A CONSTRUÇÃO

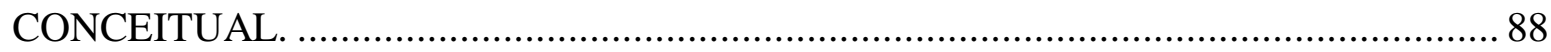

AE-3: SOLUÇÕES: ASPECTOS QUALITATIVOS - SOLUBILIDADE DO ALUMÍNIO

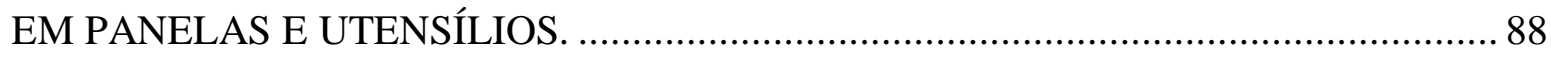

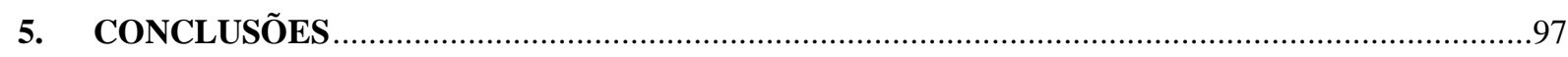

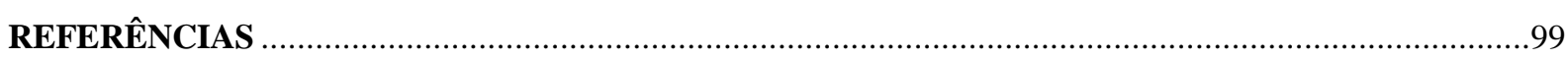

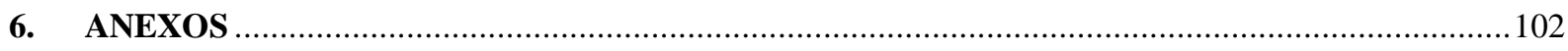




\section{APRESENTAÇÃO}

Licenciado em Química (2009), pela Faculdade de Filosofia, Ciências e Letras de Ribeirão Preto (FFCLRP), atuei como professor de química na rede particular, no "Colégio Adventista de Ribeirão Preto" (CARPRE) de 2009 a 2011.

No início de 2010 fui aprovado em um concurso público para o cargo de professor do Ensino Médio e Técnico no Centro Paula Souza (Etec Angelo Cavalheiro - Serrana/SP), e estou vinculado a esta instituição até hoje (2018).

No final de 2010, fui selecionado para desenvolver atividades de tutoria online e presencial na primeira turma do curso de Licenciatura em Ciências (LC), ofertado inicialmente pela Universidade de São Paulo (USP) em parceria com a Universidade Virtual do Estado de São Paulo (UNIVESP). Este curso foi oferecido na modalidade semipresencial (10 horas de estudos online durante a semana e 8 horas de estudos presenciais aos sábados). Atualmente sou tutor/educador deste curso, que está sob a responsabilidade da USP (2018).

De 2011 a 2012, devido as necessidades de Educação a Distância (EaD) do curso LC no qual estava vinculado, cursei uma especialização sobre Metodologias e Gestão para a Educação a Distância" na Faculdade Anhanguera de Ribeirão Preto.

De 2012 a 2014, motivado pela necessidade de ampliar meus conhecimentos junto ao Ensino de Química, cursei o mestrado presencial no Departamento de Química (DQ) da FFCLRP, cuja dissertação foi intitulada de "A Atividade Orientadora de Ensino como alternativa metodológica para a abordagem de metais pesados na disciplina de Química Analítica Qualitativa".

No $2^{\circ}$ semestre de 2014, ingressei no curso de doutorado pelo DQ/FFCLRP, inspirado pelas experiências concomitantes dos ensinos presencial e a distância nos quais estive mergulhado nos últimos anos. Assim, pela experiência de trabalho e inspirado por algumas questões, decidi investigar como seria o processo de aprendizagem de conceitos de ciências/química na modalidade a distância, utilizando atividades de ensino baseadas na teoria da atividade? Teria algum aspecto diferente daquele constatado em relação ao ensino presencial?

No ano de 2015, além de atuar como professor de Química no EM, fui também coordenador "de área" (nível Médio) na Etec Angelo Cavalheiro.

Em 2016, com a abertura do curso Técnico em Química (TQ) na mesma Etec, ministrei as disciplinas Análises de Processos Físico-Químicos I e II e também atuei 
coordenador do eixo Produção Industrial. Ainda no final de 2016, assumi a coordenação pedagógica da Unidade, concomitantemente com a coordenação do curso de Química.

Em 2017, cursei a segunda Licenciatura (Licenciatura em Pedagogia), pelo Centro Universitário de Araras Dr. Edmundo Ulson (UNAR) e continuei desenvolvendo atividades de coordenação pedagógica até os dias atuais (2018).

Também sou professor nas disciplinas de Química Analítica Qualitativa e Tecnologia dos Materiais Inorgânicos no curso TQ da Etec e Educador no curso de LC da USP, responsável pelas disciplinas Estrutura da Matéria, Luz e Ondas Eletromagnéticas e Química (2018).

Ainda em 2018, me tornei supervisor a distância dos cursos de Licenciatura em Química, Física e Biologia na Universidade Virtual do Estado de São Paulo (UNIVESP). De forma geral, o supervisor a distância possui as atribuições de acompanhar as atividades dos discentes, bem como orientar e apoiar os mediadores de ensino (que ficam situados nos polos presenciais), no desenvolvimento das atividades no Ambiente Virtual de Aprendizagem (AVA). O supervisor também propicia a interlocução entre autores-coordenadores e participa do processo avaliativo das disciplinas.

Assim, diante das experiências no ensino presencial e na educação a distância, algumas reflexões levaram a definição de nosso objeto de pesquisa, no que diz respeito a possibilidade de construções de conceitos químicos em um curso na modalidade a distância, a partir de uma organização do ensino pautada na Teoria da Atividade. O mestrado presencial e o desenvolvimento de uma AOE no ensino presencial, nos propiciou um contato inicial com a Teoria da Atividade, haveria diferença no processo de aprendizagem dos conceitos ao usar Atividades de Ensino mas na modalidade a Distância? Respostas para as perguntas citadas foram buscadas e serão discutidas nesta tese.

A tese está organizada em 5 partes. Na primeira parte, fizemos uma apresentação das definições de educação a distância e alguns conceitos relacionados a esta modalidade. Apresentamos ainda o curso de Licenciatura em Ciências EaD e atividades de ensino como estratégia possível de interações e os objetivos geral e específicos.

$\mathrm{Na}$ segunda parte, os pressupostos teóricos foram apresentados. Para tanto, foram importantes as discussões de Vigotski acerca de "linguagem", "mediação" e "formação de conceitos". Leontiev e Engeström também foram evidenciados, no que diz respeito a elaboração de Atividades de Ensino, inspiradas na Atividade Orientadora de Ensino (MOURA, 1992). 
Na terceira, o campo metodológico foi subdividido em "pesquisa" e "ensino", uma vez que a metodologia de ensino foi o desenvolvimento de atividades de ensino a distância e a metodologia de pesquisa foi qualitativa, por meio de uma investigação descritiva e análise microgenética dos dados.

Nas duas últimas partes, foram apresentados os resultados, obtidos por meio da coleta de dados na plataforma do curso EaD, discussão dos dados e conclusão da pesquisa.

\section{INTRODUÇÃO}

\section{1 - A EDUCAÇ̃̃O A DISTÂNCIA}

A Educação a Distância $(\mathrm{EaD})$ pode ser caracterizada pela construção de saberes em tempo e espaços diferenciados. Por meio desta, indivíduos que não estão no mesmo local estabelecem comunicação, compartilham informações e instauram diferentes formas de interação não presencial (MOORE \& KEARSLEY, 2007).

A EaD exige recursos didáticos que promovam interação professor-aluno, alunoaluno e principalmente favoreçam a interação do aluno com o conhecimento. Diferente de uma sala de aula presencial, o professor está presente, mas de outra maneira: respondendo mensagens internas, e-mails, participando de fóruns, aplicando tarefas e fazendo as devolutivas, entre outras atividades. Neste contexto, o material didático utilizado, bem como as estratégias incorporadas em tais materiais adquirem uma importância em relação à mediação.

Apesar da contemporaneidade do termo EaD, sua definição e caracterização podem ser identificadas ao longo da história da humanidade no sentido de que, a ampliação dos grupos sociais; a necessidade de organização e sistematização de regras coletivas e; a organização de formas de produção material de bens de consumo, levou à emergência de sistemas simbólicos de comunicação cada vez mais complexos.

Partindo desse pressuposto, poder-se-ia se considerar que a $\mathrm{EaD}$ foi iniciada quando as primeiras formas de comunicação em tempo não-real foram produzidas. Por exemplo, quando o homem primitivo fez suas primeiras representações em rochas e artefatos e as deixou expostas, outros puderam vê-las e interpretá-las, e esta prática foi sinalizando uma espécie de educação ou informação a distância.

Ao partir da tradição oral e gestual passando pelas diferentes formas de registro escrito (nas rochas, nos metais, na madeira, na cerâmica, nos tecidos, no papiro, no papel e, 
finalmente, na "tela" - do computador, do tablet, do celular, da imaginação!), a humanidade foi instituindo-se por sua capacidade de deixar marcas atemporais e com isso garantir a continuidade da espécie, a qualidade dos recursos produzidos e uma história de conquistas sem precedentes.

Mas quando a $\mathrm{EaD}$ teria surgido?

Para Mattar (2011), a EaD nasceu com os primeiros cursos por correspondência, que já propiciavam a comunicação em tempo não comum entre emissores e receptores. De acordo com o meio utilizado para esta construção de informações, a EaD estaria dividida em três gerações: a primeira geração, que teria sido marcada pelos cursos oferecidos na Europa por correspondência desde a década de 1720, seguida da segunda geração, que vinculava a utilização de instrumentos como o rádio, as fitas de áudio, cassetes, a televisão, etc. (exemplo da Universidade Aberta Britânica, 1969) e a terceira geração (décadas de 1970 e 1980), em que o computador e a Internet começaram a ganhar visibilidade no mundo.

No Brasil, merecem destaque como pioneiros em EaD, o Instituto Rádio-Monitor, fundado em 1939. Este oferecia apostilas e um kit para se montar um rádio rudimentar ao final do curso. E posteriormente, o Instituto Universal Brasileiro, que foi fundado em $1941 \mathrm{e}$ ofereceria inicialmente cursos gerais e supletivos por correspondência (MATTAR, 2011).

A EaD foi incorporada à Lei de Diretrizes e Bases da Educação Nacional em 20 de dezembro de 1996 (Lei número 9.394). E de acordo com o Decreto Lei n 5.622, de 19 de dezembro de 2005, que regulamenta a Educação a Distância no Brasil,

caracteriza-se a educação a distância como modalidade educacional na qual a mediação didático-pedagógica nos processos de ensino e aprendizagem ocorre com a utilização de meios e tecnologias de informação e comunicação, com estudantes e professores desenvolvendo atividades educativas em lugares ou tempos diversos (BRASIL, 2005).

Assim, ao se tratar de uma educação escolar mais atualizada, a definição de educação a distância se torna específica e vinculada a determinada ferramenta tecnológica.

Segundo Maia e Mattar (2007), "a EaD é uma modalidade de educação em que professores e alunos estão separados, planejada por instituições e que utiliza diversas tecnologias de comunicação" (p. 6).

No Brasil esta modalidade de ensino tem crescido muito nos últimos anos em quase todos os níveis educacionais, mas principalmente, em cursos de Ensino Superior. Uma das características mais marcantes da vida contemporânea é a mudança na relação entre os 
sujeitos e o tempo e, para otimizar essa relação, diversas estratégias têm sido criadas e uma delas é a capacitação em horários considerados alternativos.

As características diferenciadas da modalidade EaD fazem com que alguns termos ganhem destaque e alguns deles serão discutidos a seguir. Assim, ao se discutir EaD, é inevitável refletir sobre terminologias como "ambiente virtual", "realidade virtual", "virtualidade" e etc. Mas o que seria considerado "real"? O que seria considerado "virtual"? Será que estas situações se contrapõem? Sem querer aqui adentrar ao campo da filosofia, da física contemporânea ou mesmo das discussões sobre concreto e abstrato na obra marxista (apesar da proximidade teórica com este trabalho), faremos uma breve descrição, com base no campo educacional dos últimos anos sobre os termos realidade e virtualidade

\section{2 - REALIDADE E VIRTUALIDADE}

O professor Romero Tori (TORI, 2006) fez uma explanação pautada em exemplos, na tentativa de elucidar o que seria considerado "real" e "virtual". Pautado em Pierre Lévy (1996), elaborou a seguinte situação hipotética: Imagine que você dispõe de sementes de uma árvore. Esta semente seria considerada algo "real" e a árvore na qual ela poderia se transformar seria o "virtual". A referida árvore ainda pertenceria a um conjunto de todas as "possibilidades de árvore". Neste raciocínio, o "virtual" seria algo em potencial, que dependeria de outros fatores para a sua "concretização", que dependeria de determinada atualização. No caso da semente, o clima, a quantidade de chuva, a poda, e outros cuidados influenciariam no tipo de árvore a ser desenvolvida. O virtual seria um "problema" a ser resolvido. No exemplo em questão, o "desafio da semente é tornar-se uma árvore".

Contrariamente ao possível, estático e já constituído, o virtual é como o complexo problemático, o nó de tendências ou de forças que acompanha uma situação, um acontecimento, um objeto ou uma entidade qualquer, e que chama um processo de resolução: a atualização (LÉVY, 1996, p.16).

Assim "o possível", seria o contraponto do "real". Para cada real, existe uma possibilidade. Retomemos a "árvore" de várias possibilidades de crescimento, imaginemos que uma forma única foi a estabelecida. E o "virtual" seria o contraponto do "atual". A atualização de algo virtual o tornaria real. 
Pensemos em um exemplo para a nossa situação escolar: a informação. A informação por si só seria considerada algo real. Porém, a potencial utilização desta informação seria considerada algo virtual, que após ser atualizada, se tornaria real:

Figura 1: Possibilidades de real e virtual

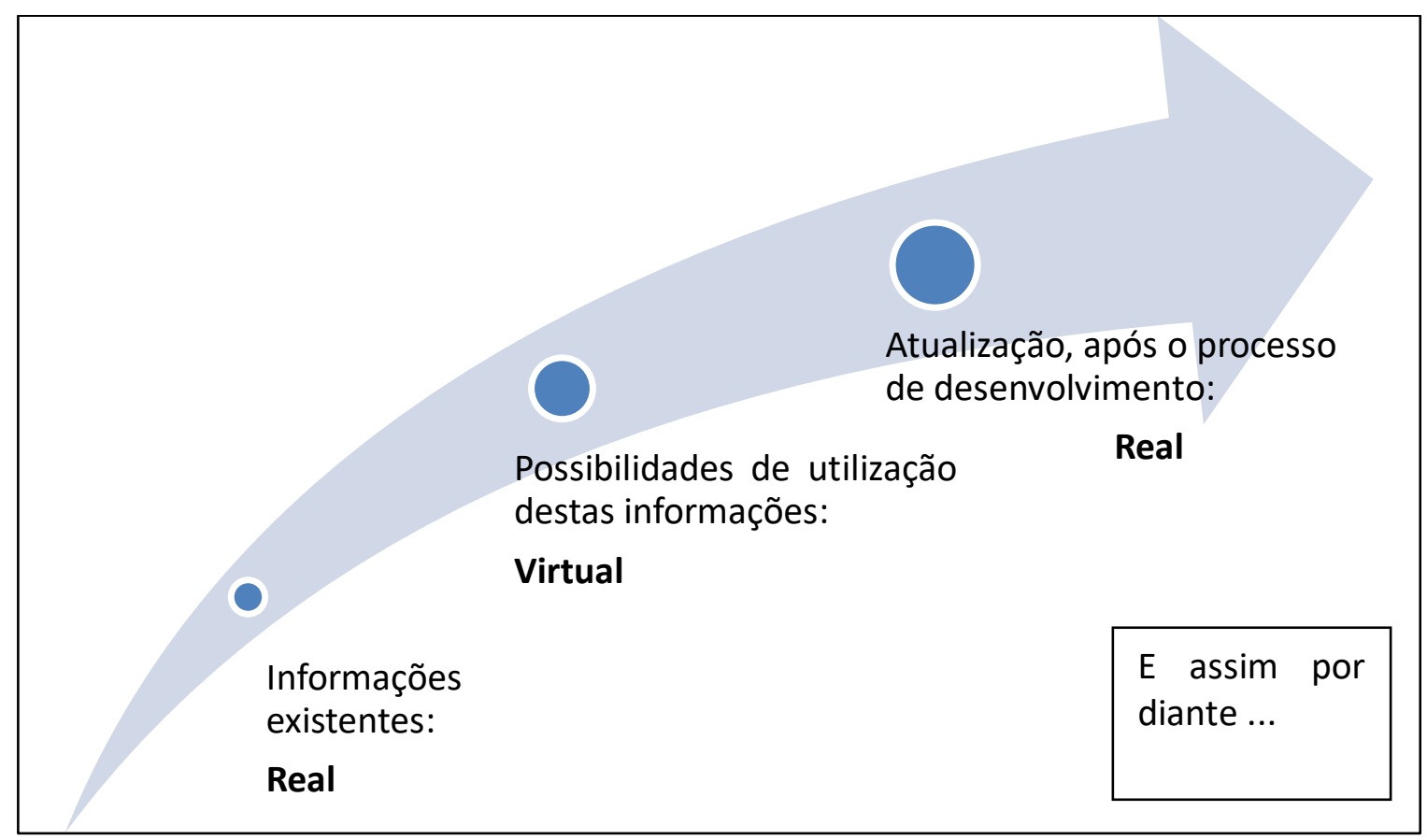

Fonte: adaptado de <http://tvcultura.com.br/videos/34695_seminario-usp-romero-tori.html>. Acesso em 15 de agosto de 2018.

Assim, as situações "real" e "virtual" iriam muito além da condição de EaD, um poderia se interconverter no outro e assim por diante. O Ambiente Virtual de Aprendizagem (AVA) está vinculado a utilização da tecnologia (da mídia digital). Este espaço seria o meio disponível para que as informações pudessem adquirir o patamar de se transformar em conhecimento (caminhos para o virtual se transformar em real). Ou seja, o AVA poderia ser considerado a sala de aula dos estudantes de um curso oferecido na modalidade a distância.

Nesse contexto, surge na década de 1990 o conceito de "realidade misturada" que foi difundido por Milgram (1994), e que define os mundos real e virtual são combinados por meio das mídias e técnicas computacionais. $\mathrm{O}$ desenvolvimento da realidade misturada pode ser representado pela seguinte figura: 
Figura 2: Realidade misturada

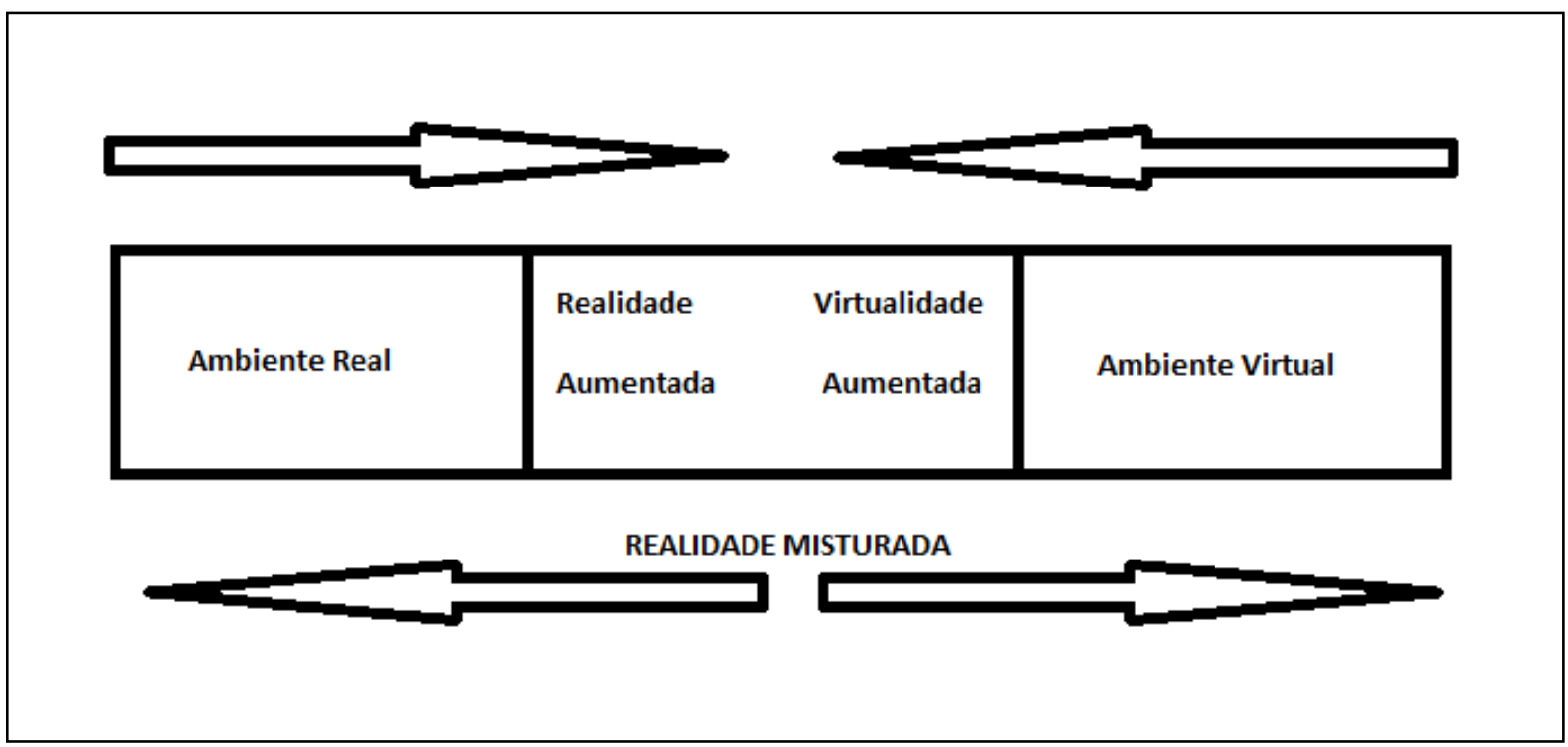

Fonte: adaptação de Milgram (1994)

Assim, a realidade aumentada ocorreria com o auxílio e inserção das mídias digitais no mundo real. Em outra perspectiva, a virtualidade aumentada ocorreria com o auxílio de objetos reais e sua inserção no mundo digital. Ambas as situações fazem parte do ambiente de realidade misturada (TORI e KIRNER, 2006).

\footnotetext{
"A realidade aumentada usa técnicas computacionais que geram, posicionam e mostram objetos virtuais integrados ao cenário real, enquanto a virtualidade aumentada usa técnicas computacionais para capturar elementos reais e reconstruí-los, como objetos virtuais realistas, colocando-os dentro de mundos virtuais e permitindo sua interação com o ambiente. Em qualquer dos casos, o funcionamento do sistema em tempo real é uma condição essencial" (TORI e KIRNER 2006, p.24).
}

Entendemos que o funcionamento do sistema como um todo é condição sine qua non para que "a distância entre os atores" seja reduzida. Esse distanciamento não se daria unicamente de forma física. Poderia ser destacado como um "distanciamento pedagógico" dos possíveis participantes. Um distanciamento denominado como "transacional". O conceito de transação foi originado em Dewey (DEWEY e BENTLEY, 1949) e evidenciaria a interação entre o ambiente, os indivíduos envolvidos e os modelos de comportamento.

Michel Moore (2002) engendrou o conceito de "distância transacional": 
A separação entre alunos e professores afeta profundamente tanto o ensino quanto a aprendizagem. Com a separação surge um espaço psicológico e comunicacional a ser transposto, um espaço de potenciais mal-entendidos entre as intervenções do instrutor e as do aluno. Este espaço psicológico e comunicacional é a distância transacional (p. 2).

Esta distância transacional poderia ser considerada um dos obstáculos da EaD. Vale destacar que a educação em massa no formato a distância, também apresentaria percalços acerca da qualidade do ensino oferecido. A figura do professor da sala de aula tradicional é diluída em uma série de profissionais (professor, autor, educador, tutor, mediador, supervisor, design instrucional - ver figuras 3 e 4), que procuram trabalhar de forma alinhada (com possibilidades de diminuição da distância transacional).

\section{3 - FORMULAÇÃO DO OBJETO DE PESQUISA}

A evasão e outras limitações pedagógicas não são especificidade somente dos cursos EaD. Talvez seja uma característica latente nos cursos de Licenciatura de forma geral. Não é rara a discussão sobre as possíveis diferenças e limitações da Educação Presencial em detrimento da Educação à Distância e vice-versa. Como se graduar a distância? Todas as áreas do saber podem ser ofertadas a distância? E com relação as especificidades de um curso de Ciências? Seria possível "ensinar ciências a distância, a partir de uma organização de ensino inspirada na Teoria da atividade?"

Essas questões auxiliaram na definição de nosso objeto de investigação: possibilidades de construção de conceitos químicos em um curso de Ciências na modalidade EaD. Em trabalhos anteriores (SANCHEZ, 2014), desenvolvemos uma Atividade Orientadora de Ensino (AOE) para um curso presencial de Ciências, mais especificamente um curso de Licenciatura em Química. Os conteúdos abordados foram: solubilidade, separação e identificação de metais pesados. Pôde-se verificar que a AOE proporcionou o estabelecimento de nexos entre informações e favoreceu a aprendizagem sobre metais pesados.

A formação presencial em Química do pesquisador e posterior atuação como tutor em um curso superior $\mathrm{EaD}$, contribuíram para o surgimento de algumas inquietações relacionadas a possibilidades de desenvolvimento de uma Atividade de Ensino (AE) para a modalidade $\mathrm{EaD}$, organizada nos moldes da AOE presencial. 
Assim, produzimos Atividades de Ensino que foram incorporadas a plataforma digital de um curso de Licenciatura em Ciências na modalidade EaD. E na busca de respostas para as inquietações surgidas no percurso é que surgiu esta tese de Doutoramento.

Em termos mais objetivos buscou-se investigar a aprendizagem de conceitos científicos por licenciandos em ciências a partir de Atividades de Ensino inspiradas na Teoria da Atividade, num curso de Educação a Distância. E, como objetivos específicos o intento foi elaborar e utilizar Atividades de Ensino (AE) para um Curso EaD de Ciências; levantar e identificar elementos que permitam caracterizar a $\mathrm{AE}$ no $\mathrm{EaD}$; investigar e discutir o papel da mediação professor-conhecimento-aluno no modelo organizativo EaD; analisar implicações entre estrutura da atividade - mediação no ambiente virtual- aprendizagens de conceitos científicos possíveis.

\section{4 - LICENCIATURA EM CIENCIASNA MODALIDADE EAD}

A questão do ensino de ciências no Brasil tem um histórico importante que envolve a formação em nível superior de professores, a importação de modelos de ensino bem como materiais didáticos e a precarização da infraestrutura escolar, especificamente dos laboratórios, dentre outras questões (NARDI; ALMEIDA, 2004, 2007, KRASILCHIK, 2000).

Além disso, no cenário brasileiro, temos encontrado na Escola Básica, professores das mais diversas áreas atuando como professores de ciências. Até meados do século XXI, o Brasil ainda possuía cursos chamados de licenciatura curta em Ciências Exatas e Naturais, mas estes cursos praticamente desapareceram depois da consolidação dos cursos de licenciatura plena nas áreas específicas da Biologia, Química e Física, que configuram disciplinas específicas no Ensino Médio. Para o Ensino Fundamental, o ensino de Ciências, enquanto área, em sua grande maioria, é ministrado por biólogos e pedagogos que desempenham funções variadas na tentativa de suprir a falta de um profissional com formação específica para atuar no denominado Ensino "Fundamental II". Estes profissionais são atuantes e de forma geral, encontram limitações de tempo para se capacitarem em um curso presencial comum (LIBÂNEO, PIMENTA, 1999).

Nesse sentido, a Universidade de São Paulo (USP) e a Universidade Virtual do Estado de São Paulo (UNIVESP), em parceria com a Fundação de Apoio à Universidade de São Paulo (FUSP), foram pioneiras em promover a formação de profissionais qualificados de forma específica para o Ensino de Ciências no Estado de São Paulo (na modalidade a distância). Iniciou-se em 2003 todo o planejamento de um curso de Licenciatura em Ciências 
(LC) que seria voltado para a formação de profissionais que objetivassem atuar no Ensino Fundamental ou para professores em exercício que atuam na Educação Básica.

Em 2010, a primeira turma ingressou por meio do processo seletivo desenvolvido pela Fundação Universitária para o Vestibular (FUVEST), no qual foram oferecidas 360 vagas, inicialmente divididas em quatro polos, localizados nas cidades de São Paulo, São Carlos, Ribeirão Preto e Piracicaba.

A partir de 2012, as vagas foram redistribuídas de forma a contemplar os novos polos nas cidades de Jaú, Lorena e Santos. Ou seja, atualmente o curso possui polos em 7 cidades, disponibilizando 120 vagas para a capital e 40 vagas para cada cidade do interior. É importante destacar que por se tratar de um curso de Licenciatura, o estágio curricular está previsto na Educação Básica. Desta forma, das 2.835 horas do curso, 1800 horas das atividades estão relacionadas com os Conteúdos Curriculares de Natureza Científico-Cultural, das quais 1470 horas são desenvolvidas a distância. As horas presenciais se subdividem em 405 horas relacionadas às práticas como componente curricular, 403 horas ao estágio supervisionado e 210 horas destinadas às atividades acadêmico-científico-culturais.

A figura abaixo reproduz a "equipe educacional" vinculada ao curso LC-USP:

Figura 3: Equipe Educacional - USP

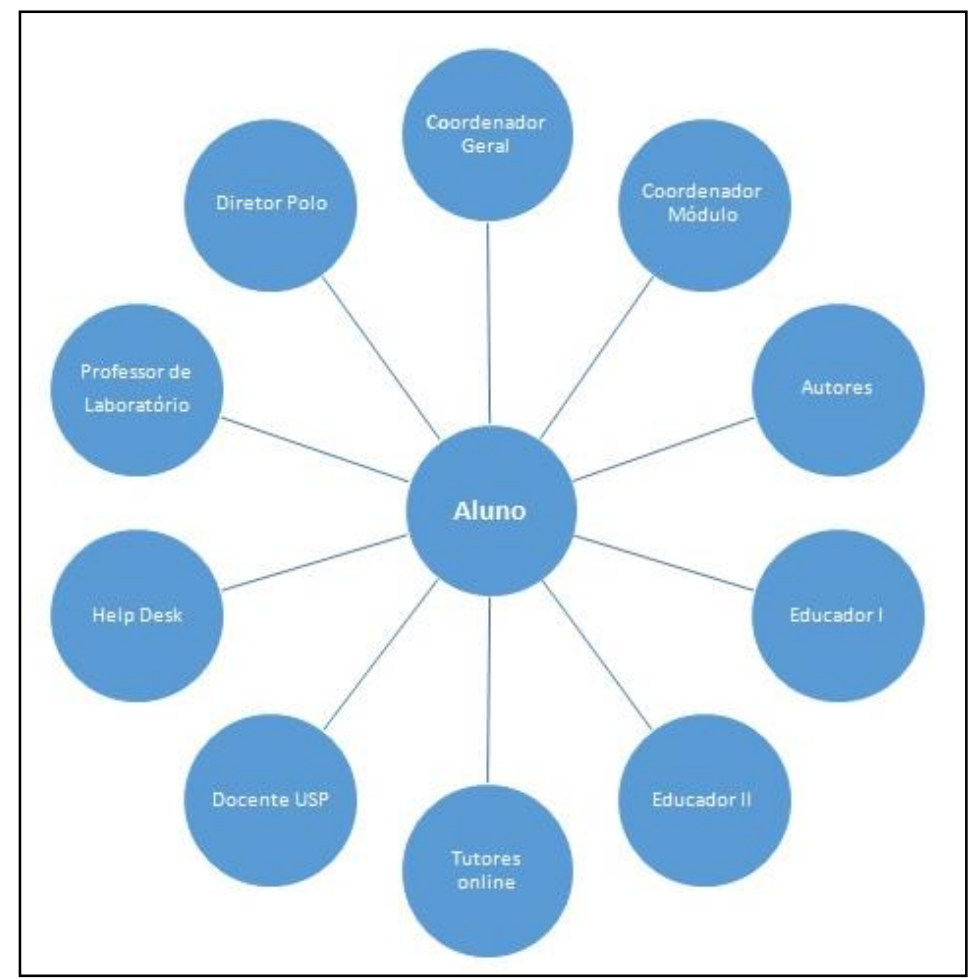

Fonte: <http://wp.liciencias.usp.br/equipe/>. Acesso em 30 de julho de 2018. 
Descrição dos atores ${ }^{1}$.

Ainda em 2012, a UNIVESP foi efetivamente criada, com o propósito de disponibilizar a tecnologia a serviço da educação e propiciar a universalização do Ensino Superior no Brasil de qualidade ${ }^{2}$.

Assim, o curso de LC passou a ser ofertado pela USP apenas e foi oferecido na modalidade semipresencial, num tempo mínimo de 8 semestres e exige pelo menos 18 horas semanais de estudos. Estas horas são distribuídas no formato $10+8$, sendo 10 horas de aulas e atividades online (desenvolvidas no Ambiente Virtual de Aprendizagem - AVA) e 8 horas presenciais, (desenvolvidas nas dependências da Universidade de São Paulo, em sábados letivos). Nestes encontros presenciais, as atividades experimentais também são desenvolvidas, bem como as avaliações escritas de cada disciplina. No que diz respeito ao polo de Ribeirão Preto, as atividades presenciais são desenvolvidas na Faculdade de Filosofia, Ciências e Letras de Ribeirão Preto (FFCLRP).

Este formato de curso permite, além da recepção de alunos das cidades nas quais os polos estão centralizados, alunos das cidades circunvizinhas e da região, uma vez que os encontros presenciais ocorrem apenas uma vez por semana (nos finais de semana). O curso semipresencial é flexível, permite maior acessibilidade dos alunos e favorece de forma mais efetiva a democratização do Ensino Superior, além de promover a capacitação e qualificação dos professores do Ensino Básico.

\footnotetext{
${ }^{1}$ Descrição dos atores: Descrição dos atores da figura' ${ }^{1}$ : Coordenador Geral- Administrador do curso. É o responsável pela gestão global de todas as ações. Coordenador de Módulo- Professor doutor da USP, deverá possuir a formação na área do conteúdo do módulo que coordenará, para supervisionar o Projeto Pedagógico do Curso e conteúdos disponibilizados como materiais; selecionar os Professores-Autores; acompanhar o desempenho de professores, tutores e educadores do módulo em questão. Professor-Autor - O Professor doutor da USP, responsável pela produção dos materiais (textos e vídeos). Educador I - Responsável pelas atividades presenciais aos sábados. Orienta e reorganiza os materiais produzidos pelos autores, de movo a oferecer atividades presenciais. É também responsável pelos Tutores. Educador II - Responsável pela elaboração e proposição de atividades interativas online. Docente USP - Responsável pela interação entre os autores e educadores e pelo desenvolvimento do curso nos Polos. Tutor - Responsável pela mediação/ interação com os alunos no AVA. Acompanhamento, orientação nos fóruns de dúvidas e de discussão. Correção de atividades online. Oferecimento de plantões de dúvidas (presenciais e virtuais). Help Desk - Serviço de atendimento as dúvidas dos alunos (em sua maioria dúvidas técnicas). Professor de Laboratório- Coordena as aulas práticaslaboratoriais desenvolvidas nos sábados presenciais. Diretor de Polo - Professor doutor responsável pela coordenação, direção acadêmica e administrativo pontualmente em cada Polos.
}

${ }^{2}$ Fonte: www.licenciaturaciencias.usp.br 
Entretanto, há certas limitações no que tange o desenvolvimento de uma graduação EaD. Não são todas as instituições que oferecem materiais, profissionais e estrutura (de forma geral) que propicie qualidade na formação, bem como não são todos os alunos $\mathrm{EaD}$ (ou candidatos a alunos), que apresentam as condições de rotina e autorregulação de estudos, disciplina, utilização de tecnologias dentre outras habilidades requeridas neste formato, para desenvolverem um curso Superior minimamente satisfatório.

Há ainda, os números expressivos relacionados a evasão, uma vez que o aluno inicia o curso acreditando ser "mais fácil" estudar no seu tempo disponível. A primeira turma do curso de LC da USP (polo Ribeirão Preto) iniciou o curso em setembro de 2010 com 90 alunos em um vestibular extraordinário (fora de fase com o vestibular da Fundação Universitária para o Vestibular - FUVEST). Desta turma, apenas 16 concluíram todas as etapas e chegaram a colação de grau no ano de 2014. Para o segundo oferecimento em 2012 (já em fase com o vestibular da FUVEST), foram oferecidas 40 vagas para o polo de Ribeirão preto, os quais 5 alunos colaram grau em 2015. A terceira turma, iniciada em 2013 totalizou 15 formados em 2016 e a quarta turma iniciada em 2014 (também com 40 alunos), finalizou com 6 formados em 2017 (ver Tabela 1):

Tabela 1. Relação Oferta x Número de Concluintes

\begin{tabular}{cccc}
\hline Ano de Ingresso & $\begin{array}{c}\text { Número de vagas } \\
\text { ofertadas }\end{array}$ & Ano de Conclusão & $\begin{array}{c}\text { Número de alunos } \\
\text { concluintes }\end{array}$ \\
\hline $2010 / 2011$ & 90 & 2014 & 16 \\
2012 & 40 & 2015 & 5 \\
2013 & 40 & 2016 & 15 \\
2014 & 40 & 2017 & 6 \\
\hline
\end{tabular}

Fonte: Serviço de Graduação da FFCLRP

Vale ressaltar (por meio desta amostragem e da experiência como tutor/educador), que o público-alvo deste curso em específico é composto em sua maioria por pessoas já inseridas no mercado de trabalho (em diversas áreas), possuem famílias (filhos, cônjuges e etc) e pouco tempo disponível aos estudos. Alguns estiveram em uma instituição de ensino há muitos anos (estão há vários anos sem estudar). Em todos os anos que o curso foi ofertado, o preenchimento das vagas disponíveis se deu por meio do acesso por "portador de diploma", possibilidade de ingresso para candidatos que já possuíam alguma graduação. 
Destarte, habilidades relacionadas a utilização das Tecnologias da Informação e Comunicação $\left(\mathrm{TICs}^{3}\right)$ são requeridas, bem como, a autonomia e a rotina de estudos . Tais habilidades podem contribuir junto a autorregulação da aprendizagem do aluno $\mathrm{EaD}$, para que estratégias de "aprender a aprender" possam ser desenvolvidas.

Em 2014, a UNIVESP ofertou 3.330 vagas em seu primeiro vestibular, para graduação em Engenharia de Computação, Engenharia de Produção e licenciaturas em Matemática, Física, Química e Biologia. Atualmente, além desses seis cursos de graduação, também são oferecidos o curso de Licenciatura em Pedagogia e especialização para a formação docente no ensino mediado pelas tecnologias. Em 2014 eram 3 mil alunos matriculados (aproximadamente) em 45 polos presenciais. Hoje são mais de 35 mil, distribuídos em 243 polos. A figura 4 a seguir, evidencia a equipe educacional nos cursos LC da UNIVESP.

${ }^{3}$ TICs: Em uma terminologia mais recente a letra "D" de digital foi incluído a sigla "TIC", para fazer referência as TICs digitais. Desta forma, em vez de "TIC", o acrograma passou a ser "TDIC" (Tecnologias Digitais de Informação e Comunicação), (TORI, 2010). 
Figura 4: Equipe Educacional - Licenciaturas/UNIVESP

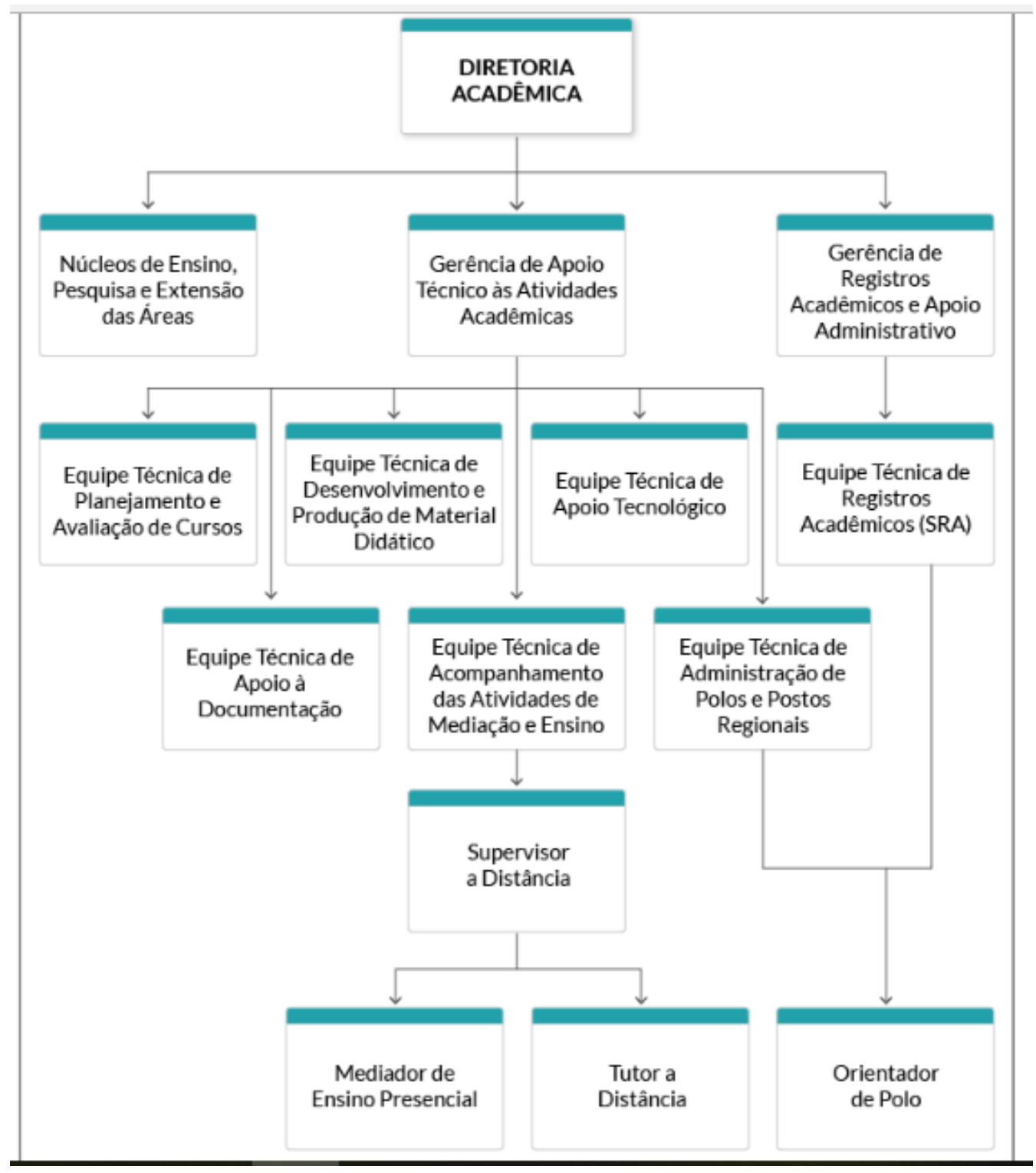

Fonte:

$<$ https://cursos.univesp.br/courses/1829/pages/estrutura-hierarquica-

univesp?module_item_id=141150>. Acesso em 30 de julho de 2018.

Descrição dos atores da figura ${ }^{4}$.

${ }^{4}$ Descrição dos atores: Diretoria Acadêmica - Gestão pedagógica geral e definição das diretrizes educacionais da UNIVESP. Núcleo de Ensino, Pesquisa e Extensão em Tecnologia e Gestão - Desenvolve os Projetos Pedagógicos dos Cursos (PPCs) e matrizes curriculares. Estabelece os autores das disciplinas. Gerência de Apoio Técnico às Atividades Acadêmicas - Coordena as equipes técnicas sob sua responsabilidade. Equipe Técnica de Planejamento e Avaliação dos Cursos - Responsável pelas avaliações institucionais e de cursos. Equipe técnica de Desenvolvimento e Produção de Material Didático - Orientação a despeito da adequação pedagógica dos diversos materiais. Desenvolvimento de recursos educacionais em diferentes linguagens, edição, revisão e diagramação dos materiais. Equipe Técnica de Administração de Polos e Postos Regionais Cadastramento, seleção de orientadores de polo e suporte aos mesmos (vistorias e auditorias). Orientador de Polo - Efetua matrícula presencial dos alunos, impressão, aplicação e envio das avaliações para correção. Responsável pela conservação do polo. Equipe Técnica de Apoio Tecnológico - apoio técnico ao usuário, manutenção de microinformática, infra-estrutura. Equipe Técnica de Apoio à Documentação - Gestão de convênios/parcerias, 
No que diz respeito à especificidade do curso de LC, vale ressaltar que além da USP, a Universidade Aberta do Brasil (UAB), também oferece o curso de Licenciatura em Ciências na modalidade a distância. Todavia, a primeira turma ingressou apenas no segundo semestre de 2013, por meio da Universidade Federal do Rio Grande (FURG), situada no Rio Grande do Sul. O curso de Ciências da FURG está organizado em interdisciplinas, a fím de superar o modelo fragmentado das ciências e o trabalho isolado das disciplinas. Com a duração de oito semestres (2955 horas) distribuídas em diferentes disciplinas de conteúdos curriculares de natureza científico-cultural e pedagógico, a oferta tem o propósito de formar professores de Ciências para atuar nos anos finais do Ensino Fundamental.

Enfim, de forma geral, um curso na modalidade a distância apresentaria particulares acerca de sua estrutura e no que diz respeito a equipe que o articula (com o foco no estudante). Da mesma forma, o aluno que se candidata a este tipo de curso, também precisaria desenvolver habilidades relacionadas a inclusão digital (e as formas disponíveis de interação), bem como ocupar um lugar importante enquanto "protagonista de seu aprendizado". Qual aluno(a) seria esperado para a $\mathrm{EaD}$ ?

\section{5 - EAD E O PROTAGONISMO DISCENTE}

Não seria privilégio da $\mathrm{EaD}$, a possibilidade de inserção do estudante como "protagonista" de seu aprendizado. Não é recente a iniciativa de descentralização da figura do "mestre" enquanto detentor de todo o conhecimento e consequente compartilhamento das ideias com o"aprendiz".

Em seu livro "Cibercultura", Pierre Levy (2008), traz reflexões acerca desta "nova" condição do professor, que em nossa entendimento não seria exclusivo da $\mathrm{EaD}$ :

documentação de professores e bolsistas. Equipe técnica de Acompanhamento das Atividades de Mediação e Ensino - Operacionalização de tutoria e supervisão. Definição fluxos de comunicação entre aluno e instituição. Suporte pedagógico/acadêmico. Supervisor a Distância - Orientação mediadores/tutores, acompanhamento pedagógico dos alunos. Intermediação dúvidas entre autores e discentes. Contato com a coordenação da área. Tutor a Distância - Acompanhamento dos alunos no AVA, orientação, mediação das dúvidas e discussões nos fóruns, correção atividades, feedback personalizado e lançamento de notas. Mediador de Ensino Presencial Acompanhamento e mediação de atividades presenciais e virtuais. Suporte ao autor e participação do processo de avaliação; orientação aos alunos junto ao desenvolvimento de atividades gerais. Gerência de Registros Acadêmicos e Apoio Administrativo - Coordenação das operações da equipe sob sua responsabilidade. Equipe Técnica de Registros Acadêmicos - Registro e controle das informações acadêmicas/vida escolar dos alunos. 
A EaD explora certas técnicas de ensino a distância, incluindo as hipermídias, as redes de comunicação interativas e todas as tecnologias intelectuais da cibercultura. Mas o essencial se encontra em um novo estilo de pedagogia, que favorece ao mesmo tempo as aprendizagens personalizadas e a aprendizagem coletiva em rede (p. 156).

Neste sentido, o professor possui papel importante na aprendizagem, mas de uma forma "orientadora" ou "mediadora", em conjunto com as demais ferramentas, atores envolvidos e as interações possíveis.

Seguindo esta linha de raciocínio, teríamos ainda as denominadas "Metodologias Ativas" $^{5 "}$ (MAs), que também focalizaram (e focalizam) o estudante enquanto agente de seu trabalho, no sentido de "colocar a mão na massa para apreensão do conhecimento".

As MAs têm suas bases em um princípio da autonomia, algo explícito no legado de Paulo Freire, no qual o aluno não deveria ser apenas um "receptor" de informações, mas ser crítico, reflexivo, para participar de maneira ativa na construção do conhecimento (que é histórico e social). Essa característica de aluno ativo junto ao seu conhecimento é crucial (e mais delineada) para o aluno EaD.

As MAs foram potencializadas pelas TDICs no sentido de disponibilizar mais ferramentas que tornem o aluno co-responsável pela busca de informações e conceitos que auxiliem na busca de solução para determinadas situações problemáticas. Assim, uma característica importante para o "estudante $\mathrm{EaD}$ ", é a iniciativa para aprender e buscar informações. O ensino por meio das TDICs traz, portanto, redefinições do ser professor, mas também do ser aluno. Neste sentido, problematiza o lugar e as funções de cada ator no cenário das relações de ensino e destaca, mais uma vez, assim como fez Paulo Freire e os referenciais desta pesquisa,Vigotski e Leontiev, que a aprendizagem é um processo ativo e responsivo, depende do ser aprendente e envolve uma complexa rede de relações com o outro e com o meio de modo geral.

Essas constatações, já conhecidas do campo educacional, anunciadas por Vigotski e descritas por Luria (1981) tem ganhado força com estudos recentes do campo das Neurociências que mostram a importância do posicionamento ativo diante dos desafios como

\footnotetext{
${ }^{5}$ Metodologias Ativas: são estruturadas por meio de estratégias pedagógicas que inserem o aluno no centro da aprendizagem, como responsável por ações diversas de caráter executivo e operacional. Fonte: <https://cursos.univesp.br/courses/1829/pages/texto-base-metodologias-ativas?module_item_id=141128>.

Acesso em 30 de julho de 2018.
} 
condição para o aumento das conexões neurais, do fortalecimento das memórias de longo prazo e, consequentemente, a melhora do aprendizado. Com isso cabe-nos questionar:

Será que existe uma relação entre a resposta de nosso corpo (estímulos corporais) e a natureza e estrutura de uma atividade que esteja sendo desenvolvida? Uma pesquisa realizada por POH et al. (2010) utilizou um sensor (não-intrusivo), integrado ao pulso, para avaliar a sensibilidade de atividade do sistema nervoso simpático durante o desenvolvimento de ações (ou tarefas) ("atividade eletrodérmica" - EDA). Participaram da pesquisa, 26 indivíduos com idades entre 18-56 anos, durante três experimentos (tarefa física, tarefa escrita, e tarefa emocional), cada um consistindo de uma linha de base, tarefa e período de recuperação, conforme proposta do experimento.

Os resultados do experimento feito com um único indivíduo durante uma semana (ver figura 5), evidenciaram que os maiores sinais (picos) de atividade eletrodérmica foram obtidos em momentos em que o ser humano estava desenvolvendo tarefas de estudos, exames, laboratórios e momentos sociais. As menores taxas foram encontradas durante as aulas convencionais expositivas (professor detentor de informação-aluno receptor passivo). 


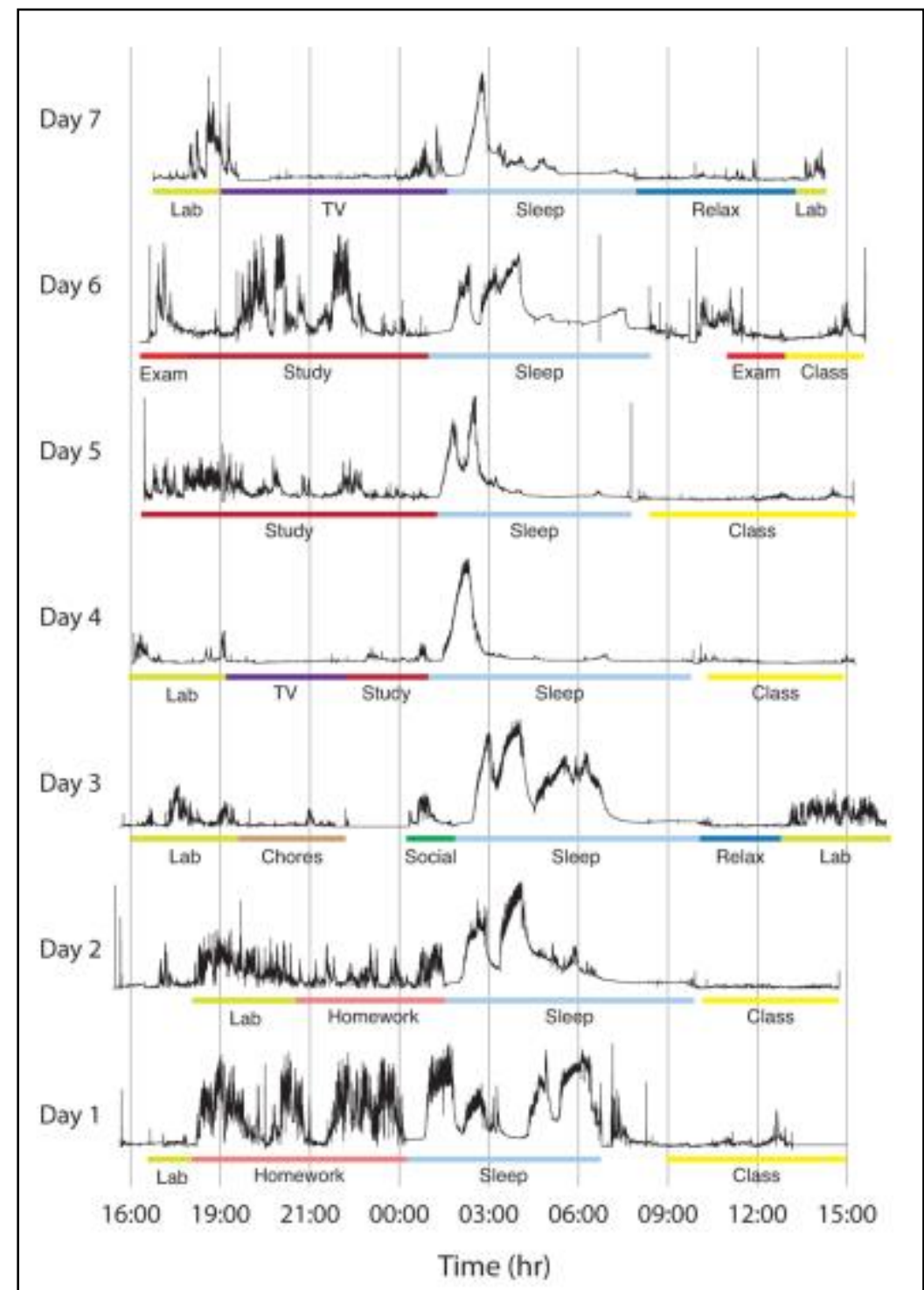

Fonte: POH, M.Z.; SWENSON, N.C.; PICARD, R.W. A Wearable Sensor for Unobtrusive, Longterm Assessment of Electrodermal Activity. Ieee Transactions on Biomedical Engineering, vol. 57, no. $5,2010$.

Assim, as situações de interações ativas, seriam as que mais beneficiariam as possibilidades de "movimentação" de sentidos. Ou seja, o estudante, para ser protagonista de seu conhecimento, precisaria se relacionar de forma ativa e dialógica com seus pares, para que situações de aprendizado pudessem ser estabelecidas, mediadas e desenvolvidas. A interação no caso deste trabalho é por meio da linguagem escrita (diálogos) realizados no AVA. Vale destacar que mesmo com questões teóricas, o aluno é colocado em uma condição ativa, a medida que é instigado pelo professor a buscar respostas e elaborar questionamentos , que são a mola propulsora para outros níveis de compreensão dos problemas. Neste sentido, entendemos que a pesquisa supracitada pode nos ajudar a entender a importância da postura 
ativa do aluno da $\mathrm{EaD}$ diante dos recursos tecnológicos que, sem a figura presencial do professor a instigar-lhe uma resposta, precisa buscar, ele primeiro a pergunta e depois conferir resposta.

Em um curso EaD, esta possibilidade de participação ativa poderia minimizar o distanciamento que as condições físicas impõem. Todavia, em decorrência da experiência de trabalho do presente autor, acredito que os meios para o desenvolvimento desta "atuação ativa" do estudante ainda estão latentes no processo de "virtualização do ensino".

\section{FUNDAMENTAÇÃO TEÓRICA}

Com origem na Psicologia Histórico-Cultural (PHC) de Vigotski, Leontiev e Luria, a Teoria da Atividade (TA) foi inicialmente apresentada como uma abordagem interdisciplinar das ciências humanas. Ela evidencia um sistema de atividade coletiva orientado a objetos (mediado por artefatos), relacionando assim, o sujeito individual e a estrutura da sociedade.

Segundo Engeström, Miettinen e Punamäki (1999), de forma geral, a TA possuiria três origens históricas: na filosofia clássica alemã (de Kant a Hegel), nos escritos de Marx e Engels e na PHC russa soviética de Vigotski, Leontev e Luria.

Moura (1992), a partir da Teoria da Atividade de Leontiev (1978), propôs uma forma de organizar o ensino (de Matemática inicialmente) como atividade e criou (e vem desenvolvendo) a Atividade Orientadora de Ensino (AOE). A AOE mantém a estrutura da atividade proposta por Leontiev, no que diz respeito a uma necessidade (que neste caso seria a apropriação da cultura), o motivo (que seria apropriação do conhecimento), o objetivo (que seria o ensino e a aprendizagem) e a proposição de ações que poderiam considerar as condições da Escola (MOURA et. al, 2010).

Assim, a atividade seria um processo psíquico dirigido a um objeto (material ou não) que coincide com o objetivo que instiga o sujeito a desenvolvê-la, ou seja, se torna o motivo para o seu desenvolvimento. Todavia, o motivo enquanto apropriação de cultura (ou conhecimento), nem sempre coincide com o objetivo do sujeito e nessas condições de não coincidência, em vez de atividade psíquica, teríamos apenas uma "ação" (LEONTIEV, 2017).

Se determinado estudante inicia a leitura de um livro para se preparar para uma prova ou qualquer exame. Durante o processo, descobre que o referido livro não será mais "cobrado" em tal avaliação. Assim, se ele decidir parar de ler este livro, estaria evidente que o motivo que o levou a leitura não seria o conteúdo do mesmo. Desta forma, esta ação de leitura não seria considerada uma atividade. Porém, se mesmo com a informação da não 
obrigatoriedade do livro para tal exame, o estudante continuasse a leitura, o motivo coincidiria com o objetivo que o levou a desenvolver tal atividade e desta forma, teríamos a possibilidade de atividade psíquica (LEONTIEV, 2017).

No caso de nossas aulas, a situação poderia ser similar. Se o aluno frequentar a Escola obrigado pelos pais, o motivo inicial não coincidiria com o objetivo de apropriação de conceitos. Mas se com o passar do tempo e das aulas, o aluno "se motivar" no sentido cultural deste espaço, haveria a possibilidade de seu desenvolvimento por meio de atividade psíquica.

$\mathrm{Na}$ AOE como unidade formativa, professor e aluno possuem a necessidade de ensinar e aprender, respectivamente. Para que esta se efetive, ambos os sujeitos deverão "entrar em atividade, com um motivo coincidente com o objetivo". O professor em atividade reestrutura seus conhecimentos por meio de ações e operações organizadas, o que caracteriza a AOE como unidade de formação de professor e aluno (MOURA et. al, 2010). O aluno em atividade reestrutura seus conhecimentos por meio de ações e operações, com o objetivo de adquirir o conhecimento novo. A figura abaixo representa as condições estruturantes da AOE:

Figura 6: Estrutura da AOE

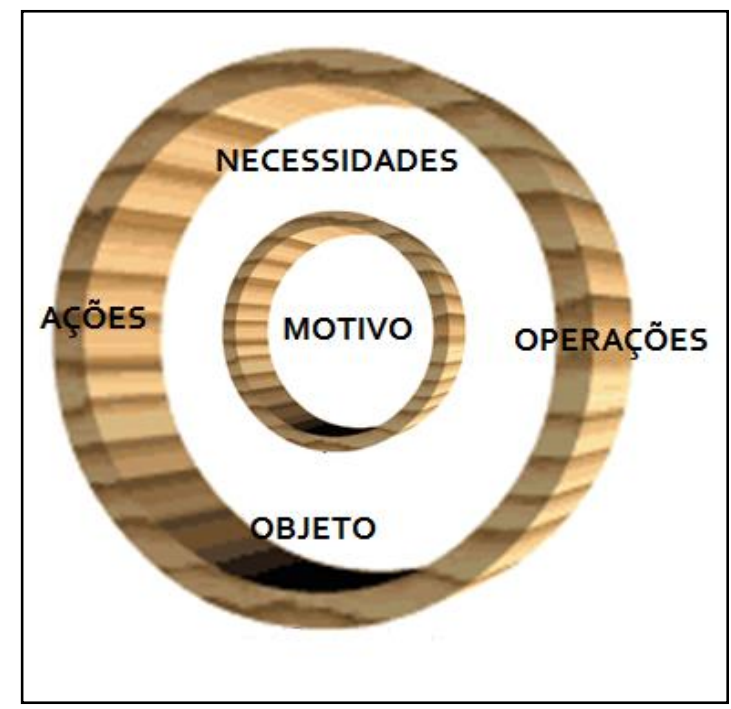

Fonte: Adaptação de Espimpolo (2012)

Para despertar nos alunos a necessidade de apropriação de conceitos, situações desencadeadoras de aprendizagens precisam ser estruturadas. Nestas situações, são apresentadas problemáticas (com a origem do conceito a ser discutido) refletidas pelos alunos, com o intuito de possibilitar mobilizações (físicas e psíquicas) por meio de ações e operações (MOURA et. al, 2010).

$\mathrm{Na}$ experiência presencial, desenvolvemos uma AOE para um curso de Química, no qual a mediação das situações desencadeadoras se tornou acessível pelo contato físico comum 
a todos os envolvidos: professores/pesquisadores e alunos em uma sala de aula tradicional, no mesmo dia, local e horário. A atividade de ensino presencial, descrita no mestrado, foi adaptada para modalidade a distância e designada como AE1 neste tese. A situação que nos submetemos nesta nova etapa foi diferenciada. Em uma plataforma digital não tínhamos o "olho no olho" e muito menos feedbacks tão imediatos como as expressões verbais, faciais e corporais de nossos alunos.

No caso das atividades desenvolvidas para o curso na modalidade a distância, foram apresentadas aos alunos (na plataforma virtual), algumas notícias que traziam informações sobre assuntos de interesse coletivo de maneira contestadora. As situações apresentadas de certa forma instigariam o desenvolvimento do conceito, por meio da busca de compreensão da problemática e busca de solução para o problema. O título das notícias foram "Produto aumenta prazo de validade de alimentos atacados por bactérias e fungos" (Atividade de Ensino 2 - AE2) e "Cozinhar em panelas de alumínio é perigoso" (Atividade de Ensino 3 $\mathrm{AE} 3)$. Estas duas últimas atividades foram desenvolvidas especificamente para o curso EaD.

\section{Para MORETTI (2007),}

(...) a atividade orientadora de ensino insere-se numa atividade mais geral que é a atividade de ensino cuja necessidade que a motiva é ensinar e para isso é necessário organizar o ensino de modo a favorecer a aprendizagem dos alunos - o que é a necessidade da atividade orientadora de ensino. Assim, a atividade orientadora de ensino transforma-se em uma das ações da atividade de ensino (p.99-100). (grifo do autor).

Assim, a Atividade de Ensino (AE) poderia ser considerada ainda mais "ampla" e menos "específica" do que a AOE. Por este motivo, consideramos que em nosso trabalho, foram organizadas AEs. O processo de organização e desenvolvimento das AEs, perpassou pela escolha dos temas, das reportagens sobre o conteúdo, escolha das ferramentas e do período de disponibilização, estudos, reflexões, elaboração das "questões avaliativas" e "questões norteadoras", entre outras atividades.

Antes, durante e depois de uma aula "convencional" o professor encontra-se em AE, sendo esta atividade processo e não produto (MORETTI, 2007).

Desta maneira, vale ressaltar que nosso trabalho está direcionado às possibilidades de construção de conceitos químicos em um curso no formato $\mathrm{EaD}$, no qual as AEs foram inseridas e utilizadas como recursos teórico-metodológicos. As AEs não foram o foco, mas 
sim o meio para o desenvolvimento de nosso estudo e nesta condição, procuramos elencar seus aspectos organizacionais.

\section{1 - TEORIA DA ATIVIDADE E A EAD}

A AOE proposta por Moura (1992) mantém os preceitos da Teoria da Atividade de Leontiev e seus colaboradores ao longo da história. E segundo Engeström (1999), a mediação seria o termo unificador/conector entre os trabalhos de Vigotski, Leontiev, Luria e outros representantes importantes da Escola Soviética Histórico-Cultural.

Dos referidos autores, Vigotski é considerado o precursor da Teoria da Atividade, no que diz respeito a uma mediação por meio de artefatos, a ser estabelecida entre o sujeito e um objeto (material ou não):

Figura 7: Uma tríade representação de ações

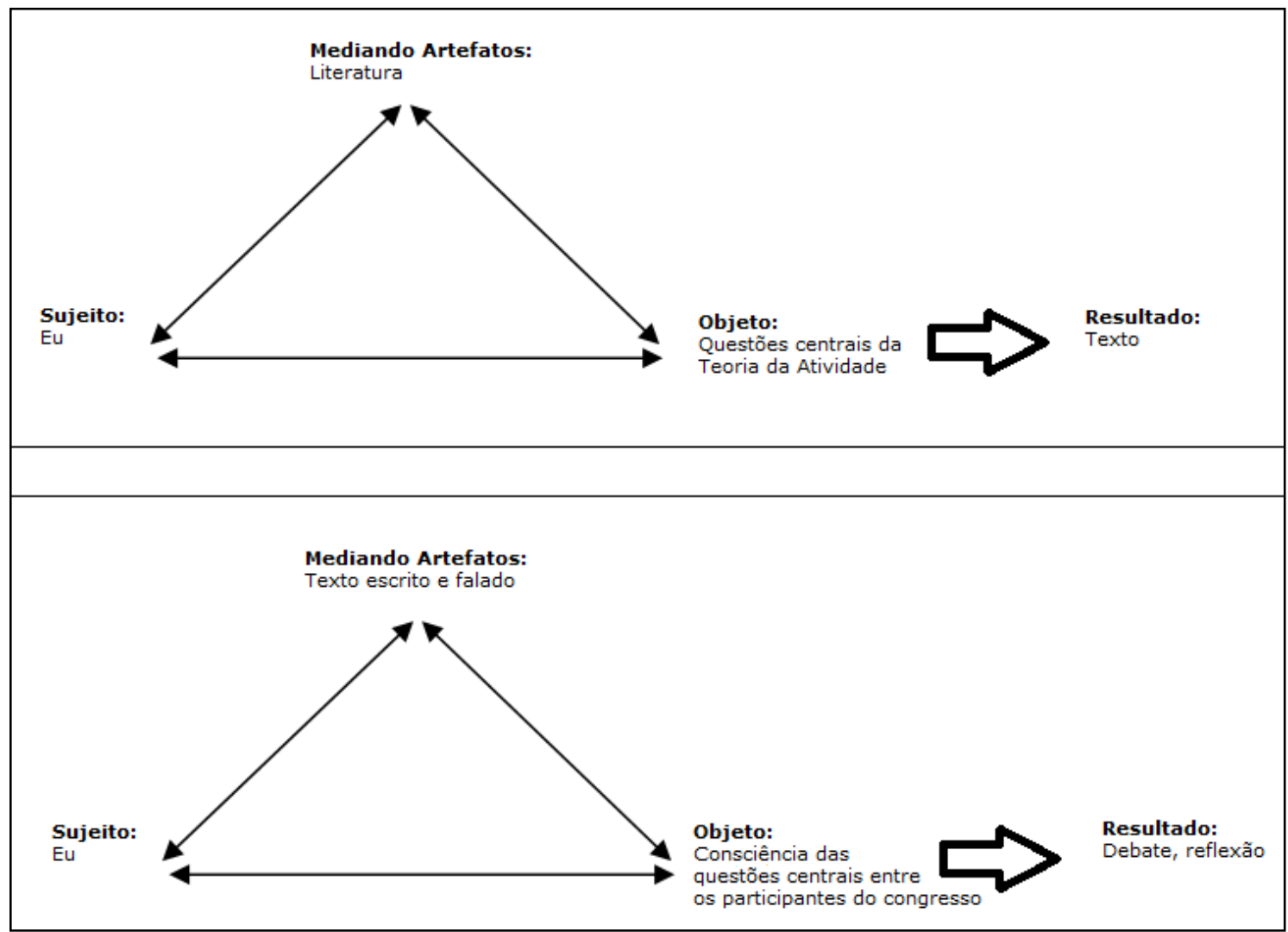

Fonte: Engeström, 1999. p. 30 (tradução nossa).

Entendemos que Engeström (1999), fez a utilização da metalinguagem na tríade tradicional (sujeito-fator de mediação-objeto) representada na figura 7, para explanar que, ao se organizar para a escrita do capítulo de um livro sobre a TA (condição de autor/escritor), ele utilizou textos da literatura enquanto artefatos de mediação (primeiro triângulo da figura 7). Já o segundo triângulo da figura acima, representaria um momento posterior, em que o autor 
poderia apresentar o seu texto em um congresso científico, bem como fazer o uso da palavra enquanto artefato de mediação.

Porém, segundo Engeström, nesta figura há uma limitação de representação:

a descrição da natureza social e colaborativa de suas ações ao desenvolver o texto estaria prejudicada, ações estas que são consideradas eventos em um sistema de atividade coletiva. Assim, esse nível de representação ocultaria o motivo por trás das ações (p. 30).

De certa forma, acreditamos que o nosso trabalho desenvolvido em uma plataforma digital, mais especificamente em um "fórum de discussão", também apresentaria esta limitação. Seria necessário tentar reconhecer a natureza social e colaborativa das ações desenvolvidas nesta ferramenta virtual, bem como evidenciá-las. O "eu aluno", ou o "eu tutor", ou o "eu autor" que eventualmente tenha efetuado alguma postagem (escrita) na plataforma virtual seria muito mais complexo e abrangente do que aquele texto (ou frase publicada) enquanto artefato de mediação.

Assim, na tentativa de contornar estas possíveis limitações, buscamos outras contribuições nos trabalhos de Engeström que possam auxiliar na compreensão de nosso contexto de investigação. O autor apresentou um modelo "expandido" do triângulo tradicional, reproduzido a seguir:

Figura 8: Um modelo complexo do sistema de atividade

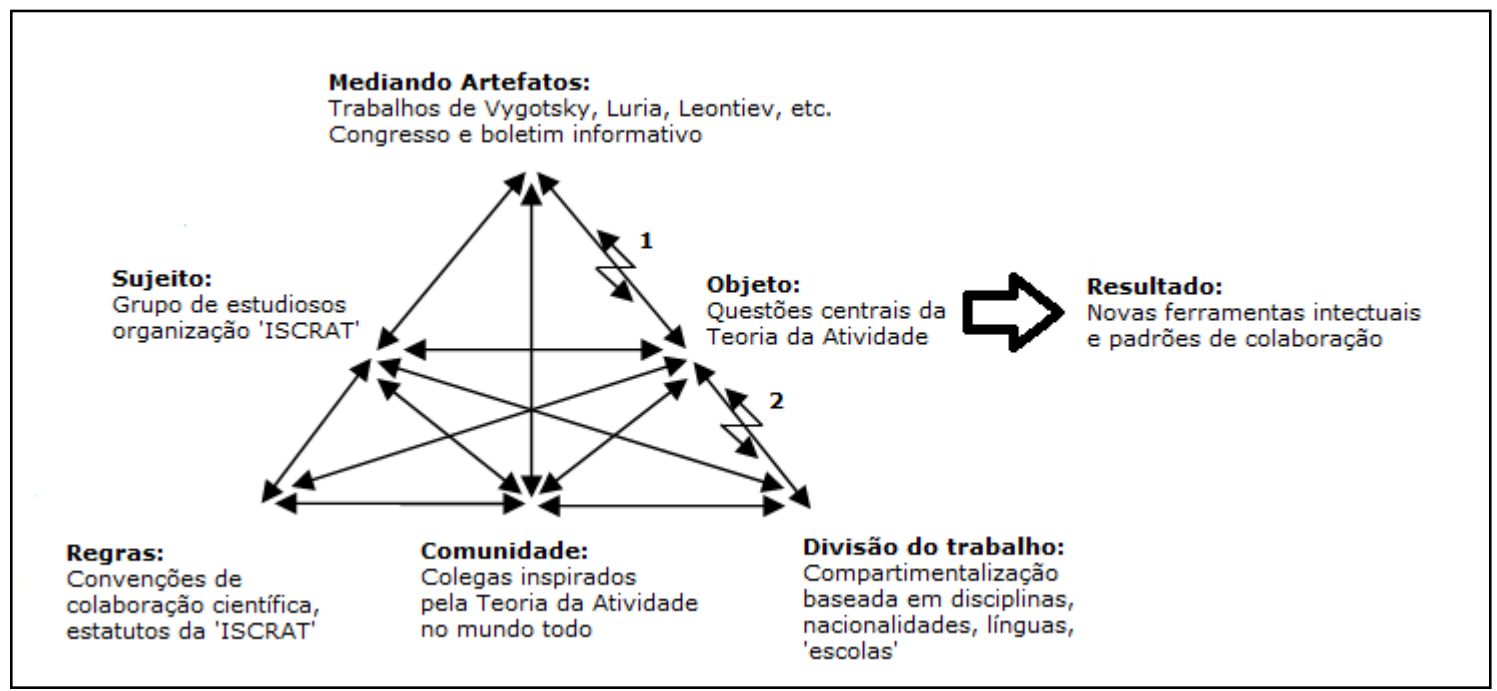

Fonte: Engeström, 1999. p. 31

Nesta proposição, o sujeito foi alterado não sendo mais o autor do texto como único indivíduo e sim um grupo de estudiosos relacionados a temática da TA (Society for Cultural Research and Activity Theory - ISCRAT). O objeto, continuou sendo "as questões centrais da TA" que interconectam as ações individuais e coletivas, todavia, o resultado que seria mais momentâneo e situacional na representação da figura 7 (um texto "acabado" ou um trabalho 
apresentado), foi modificado para "ferramentas intelectuais" e "padrões de colaboração", para que significados pudessem ser evidenciados e objetivados socialmente em padrões de interação relativamente duradouros (figura 8).

Ao retomar o curso de LC ofertado em uma plataforma virtual, no qual alunos, pesquisadores/professores/autores, tutores e outros atores constituem "grupos" em busca da construção de determinado objeto, este modelo do sistema de atividade no pareceu pertinente. Nesta proposição, poderiam ser visualizados vários triângulos (pelo menos quatro) inscritos em um triângulo maior. Assim, novos vértices foram produzidos, bem como novos tópicos de correlação entre estes respectivos vértices (interpretação nossa).

Podemos notar que no vértice do triângulo relativo a mediação, são evidenciados os trabalhos de Vigotski, Leontiev e Luria e outros acerca da TA e também as reuniões, publicações, congressos sobre o referido assunto. Do lado direito do triângulo maior, foram introduzidos dois números. Em 1, foi apresentada uma flecha com duas pontas em forma de raio, localizada entre o objeto e os artefatos de mediação. Em 2, foi adicionada outra seta no mesmo forma raio (sentido oposto), entre o objeto e a divisão do trabalho. Segundo o autor, estas representações simulariam contradições entre os componentes centrais do sistema de atividade.

Estas contradições ficariam entre as questões desafiadoras que a TA enfrenta e os instrumentos "frágeis" de colaboração disponíveis. E também entre as questões desafiadoras e a divisão fragmentada do trabalho, que mantém separadas disciplinas, grupos nacionais, e etc limitando a discussão conjunta. As contradições também seriam "força-motriz" para mudança de patamar durante o desenvolvimento da atividade. Segundo o autor, nesta nova representação o resultado não seria mais momentâneo e dependente da situação. Em vez disso, consistiria em importantes significados objetivados e novos padrões relativamente duradouros de interações. Ou seja, uma projeção a partir de objeto para o resultado que, funcionaria como o motivo desta atividade e daria sentido mais amplo para as ações. Seria muito proveitoso passar da análise de ações individuais para a análise de seu contexto de atividade mais amplo e vice-versa (ENGESTRÖM, 1999).

Um exemplo desta possibilidade, será reproduzido a seguir:

No curso EaD, o tutor possui a atividade de mediar as dúvidas trazidas pelos alunos na plataforma virtual. Assim, por meio das discussões, conceitos poderiam ser construídos/apreendidos, no contexto em que a atividade foi inserida, valorizando-se a participação de todos (direta ou indiretamente). A "comunidade" nesta situação, seria composta pelos professores/autores do material, os tutores, os alunos, os designs instrucionais 
entre outros atores possíveis na estrutura $\mathrm{EaD}$. As regras (prazo para resposta no fórum, número de caracteres, possível avaliação, etc) também "mediariam" essa construção. Ainda em nossa realidade de Educação a Distância, as contradições também poderiam ser reconhecidas na fragmentação da "atividade docente" nos diversos atores citados acima. Essa "diluição" do papel do professor é um dos desafios a ser superado. Há ainda a necessidade de adaptação dos participantes que tradicionalmente possuem raízes na educação presencial, as quais gerariam contradições ao se depararem com a EaD.

De acordo com Engeström (1987), a TA perpassou por duas gerações e está em desenvolvimento em uma terceira. A primeira geração teria sido marcada pelos trabalhos de Vigotski e a mediação entre o sujeito e o objeto por meio dos artefatos (ver figura 7). A segunda teria sido evidenciada pelos trabalhos de Leontiev, que vinculou a coletividade na mediação, ao considerar as inter-relações dos indivíduos. A terceira consideraria diferentes redes de sistemas de atividade em interação (ver figura 8). Para a nossa pesquisa em questão, a terceira possibilidade (considerada uma expansão em relação as duas primeiras) seria mais adequada.

Em sua forma mais atualizada a Teoria da Atividade, poderia ser resumida em 5 princípios, de acordo com Engeström (2001):

O primeiro é o sistema de atividade coletiva, mediado por artefatos e orientado a objetos;

O segundo princípio seriam as múltiplas vozes (interesses múltiplos, posições, vontades e possibilidades de cada indivíduo e do todo);

O terceiro princípio seria a historicidade. Os sistemas são desenvolvidos e transformados durante o tempo;

O quarto seria evidenciado pelo papel das contradições enquanto possibilidades de mudança e desenvolvimento. Vale ressaltar que estas contradições não teriam aqui o mesmo significado que problema ou conflito. Quando por exemplo um sistema é substituído por outro, ou até mesmo um curso de natureza presencial é ofertado na modalidade a distância, possíveis contradições poderão ser detectadas nas regras acadêmicas e na vida escolar e pedagógica do aluno. Essas contradições poderiam ser utilizadas como mola propulsora para a inovação e mudança estrutural.

O quinto princípio vislumbraria a possibilidade de transformações expansivas no sistema de atividade. O termo "transformação expansiva" foi utilizado por Engeström (2001), quando o objeto e o motivo da atividade são passíveis de conceitualização em detrimento de novas possibilidades emergentes no sistema em rede. Assim, "A transformação expansiva 
poderia ainda ser entendida como uma jornada coletiva pela zona de desenvolvimento próximo da atividade" (ENGESTRÖM 2001, p. 137).

Em suma, a análise do contexto do indivíduo e de suas inter-relações sociais deverão ser valorizadas, pois o contexto do indivíduo possui papel importante na formação dos conceitos e de si mesmo enquanto indivíduo. Acreditamos que a proposta da $\mathrm{AE}$ viria ao encontro dessa possibilidade de valorização do contexto histórico-social dos indivíduos envolvidos. Concordamos com Engeström (1999), que a representação do sistema de atividade precisaria ser mais consistente, no sentido de ilustrar melhor as interações, objetivações e contradições de uma atividade desenvolvida socialmente. Entendemos que o autor fez o uso da metalinguagem para exemplificar o complexo sistema de atividade, utilizando a produção de trabalhos científicos relativos a TA como temática.

Assim, na tentativa de delinear a realidade latente em nosso curso, fizemos uma adaptação da figura 7 - "Sistema de Atividade", na qual foi inserido o tema "Educação a Distância em Ciências" como objeto:

Figura 9: Adaptação do modelo de Sistema de Atividade para EaD em Ciências

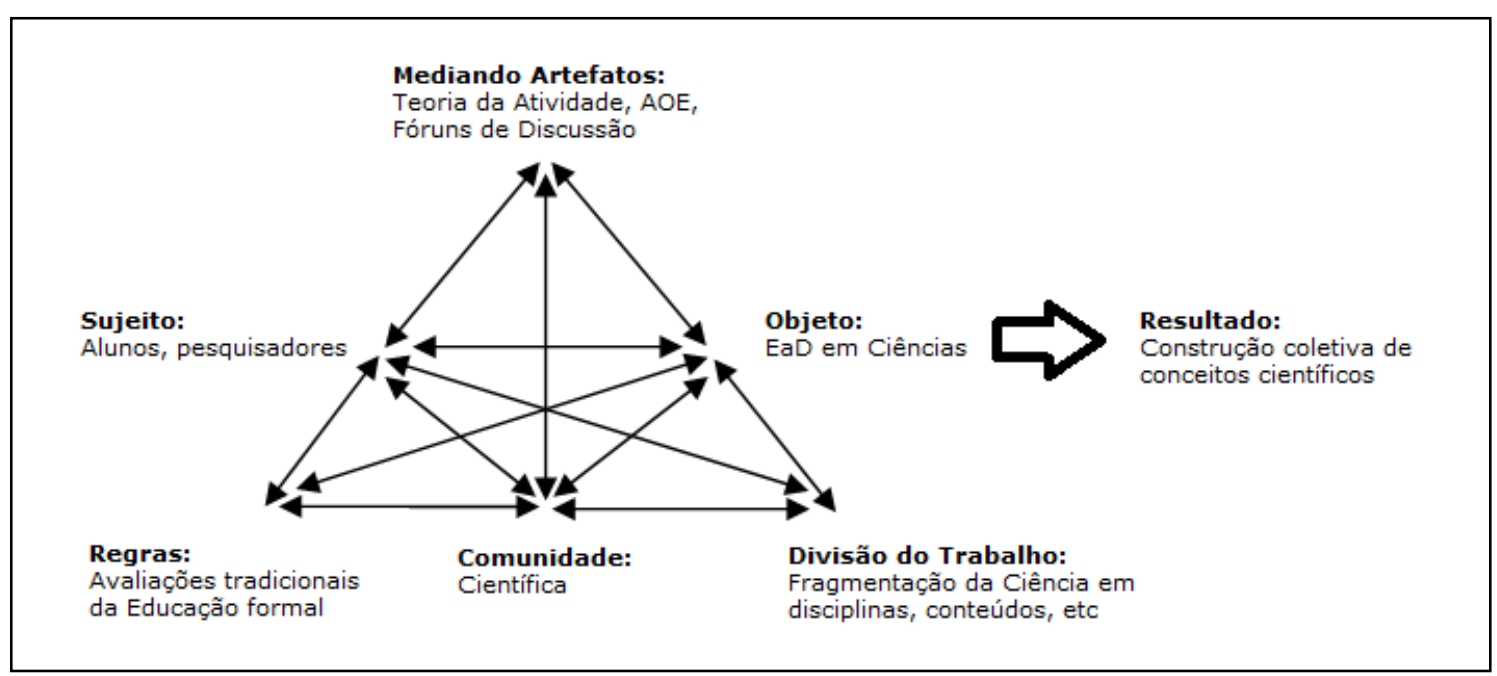

Fonte: Adaptação - Engeström, 1999

Sabemos da complexidade do sistema e da Teoria da Atividade como um todo e não seria nossa intenção reduzi-la. Esta proposta foi pensada com o intuito de mimetizar o trabalho desenvolvido em uma plataforma virtual, para a aprendizagem de conteúdos de ciências.

Nesta adaptação, segundo a proposta de Engeström (1999), alunos e pesquisadores foram inseridos como sujeitos em um dos vértices, com possibilidades de mediação entre todos os envolvidos. As setas com pontas duplas indicam que esta socialização não é 
unilateral e perpassa pelos artefatos, comunidade, pelas regras, pelo objeto e pela divisão do trabalho (que é fragmentado). O resultado desta ação mediada poderia ser evidenciado por meio da construção de conceitos historicamente estabelecidos.

Assim, entendemos que na situação virtual seria possível o desenvolvimento de uma Atividade de Ensino (AE), organizada nos moldes da AOE. Mas como desenvolver a mediação nesta configuração virtual de atividade? Qual(is) motivo(s) levaria(m) os alunos a participarem efetivamente desta AE? Qual(is) influência(s) da tecnologia neste processo?

\title{
2.2 - TEORIA DA ATIVIDADE E A COMPUTAÇ̃O
}

Na busca de suporte teórico para as indagações acerca da TA vinculada a utilização de tecnologias, nos deparamos com a discussão acerca dos efeitos psicológicos da possibilidade de "informatização da atividade", bem como da discussão de outra teoria denominada "Teoria da Atividade Criativa" (TAC).

De acordo com Tikhomirov (1999),

\begin{abstract}
A atividade criativa, mantendo-se a prerrogativa dos seres humanos, é consideravelmente alterada no contexto do uso do computador. Em condições de informatização (...) surgem novas formas de trabalho criativo, educação e brincadeira, formas que são simplesmente impossíveis sem computadores. Ao mesmo tempo, novos tipos de atividades rotineiras e estereotipadas aparecem (p. 352-353).
\end{abstract}

Assim, sabemos que na contemporaneidade, os computadores ou utilização de mídias são artefatos comuns entre os jovens e fazem parte da rotina das crianças desde o seu nascimento. Estas tecnologias estão nos lares, uma vez que é muito comum os pais deixarem seus filhos (com poucos anos de idade) "brincarem" ou assistirem vídeos em seus tablets e smartfones, bem como da utilização dos mesmos em escolas e por vezes até em creches. Porém, quando nos deparamos com um público menos jovem, alguns medos e receios acerca da utilização destas tecnologias são encontrados em um extremo, bem como a utilização desenfreada em outro.

No sentido de "se educar a distância", alguns especialistas (TORI, KIRNER e SISCOUTTO, 2006 entre outros) evidenciam que, enquanto os estudantes não se familiarizam com o mínimo necessário das tecnologias digitais (ao ponto de estas tecnologias se tornarem imperceptíveis), eles não conseguem focar nos estudos e no desenvolvimento das atividades. Assim, novos tipos de atividades rotineiras têm sido evidenciadas, incluindo crianças, jovens, 
adultos e idosos, e novas formas de "utilização criativa dessas ferramentas" tem sido encontradas em todas as esferas sociais (educação, lazer, trabalho, etc).

O mesmo autor, fez ainda uma explanação acerca das condições estruturantes da "atividade" quando desenvolvida de forma "criativa" pela utilização de computadores. Para Tikhomirov (1999), uma transformação ocorreria em todo o sistema de motivos, ao se participar da regulação da atividade criativa:

\begin{abstract}
A atividade criativa é caracterizada não apenas por motivos, metas e operações (que também existem na atividade rotineira), mas também por atos que geram novos motivos, objetivos e operações. Esta atividade sofre desenvolvimento funcional no curso de sua realização. A atividade criativa pode ser definida como uma unidade de vida que inclui a geração de novas formações psíquicas, cuja função real é dar aos humanos a oportunidade de gerar um novo mundo de objetos. Novas formações psíquicas em atividade precedem e preparam a produção de novos resultados tangíveis (produtos) de atividade (p. 350).
\end{abstract}

Em uma interpretação nossa acerca das possibilidades do desenvolvimento da atividade, definida como "rotineira" ou "criativa" por Tikhomirov, acreditamos ser complexo delinear essa diferenciação. Cremos que em situações de atividade, haverá possibilidades de geração de novos motivos, objetivos, novas reflexões e formações psíquicas durante o desenvolvimento do processo. Todavia, concordamos com o autor que a tecnologia poderia contribuir para modificações, no sentido de propiciar novas formas de atividade (independentemente de ser considerada criativa ou não), formas com determinadas especificidades que seriam impossíveis sem o computador. Neste limiar, estariam as nossas AEs, elaboradas para serem desenvolvidas com o auxílio de tecnologias (computador e internet), que serão melhores explanadas na metodologia deste trabalho.

Por fim, faz-se necessário destacar que nestas AEs inseridas na plataforma virtual do curso, a palavra escrita foi a forma de "verbalização" presente (e mais evidente) durante a atividade (ferramenta utilizada para a possível apreensão conceitual). Vale ressaltar que, mesmo que outras facetas (vértices) do complexo sistema de atividade possam estar presentes neste desenvolvimento, estas seriam menos explícitas.

\title{
2.3 - FORMAÇÃO DE CONCEITOS
}

Durante o desenvolvimento das AEs em um ambiente virtual, a "palavra escrita" foi a "ferramenta" utilizada para o estabelecimento de discussões, reflexões e possíveis construções conceituais. De acordo com Vigotski (2001): 
Todas as funções psíquicas de grau mais elevado são processos mediados e os signos são os meios fundamentais utilizados para os dominar e orientar. $\mathrm{O}$ signo mediador é incorporado na sua estrutura como parte indispensável a bem dizer fulcral do processo total. Na gênese do conceito, esse signo é a palavra, que a princípio desempenha o papel de meio deformação de um conceito, transformando-se mais tarde em símbolo (p. 59).

Para Vigotski, a formação dos conceitos se opera em 3 diferentes fases, que poderiam ser estudadas por meio do método de "duplo estímulo" ou "duas possibilidades de estímulos": uma como objeto da atividade e outra como "signo", que seria também utilizado para a organização da atividade. A primeira fase poderia ser exemplificada por um bebê, ao ser colocado pela mãe em um local repleto de diferentes objetos variados (sem maiores organizações), objetos estes que seriam passíveis de manipulação. A criança poderia manipular todos os objetos, ou os que mais chamassem a sua atenção, porém sem um estabelecimento orientado de significação. Neste momento, as palavras ou as possibilidades de sua significação, seriam um "amontoado sincrético", passível de instabilidade. A segunda fase, é denominada por Vigotski como "pensamento por complexos", no sentido da possibilidade de existência de relações entre os objetos (inicialmente isolados e munidos por impressões subjetivas). "Um complexo" não seria ainda "um conceito",

enquanto os conceitos agrupam os objetos em função de um atributo, as ligações que unem os elementos de um complexo com o todo e entre si podem ser tão diversas quanto os contatos e as relações existentes na realidade entre os elementos (VIGOSTKI, 2001, p. 65).

O "último estágio de um complexo", foi denominado por Vigotski como "pseudoconceito", e não seria considerado um conceito propriamente dito, pelo fato de ainda apresentar associações vinculadas ao concreto (sensorial).

Um exemplo deste possível "pseudo-conceito", importante para a comunicação entre adulto e crianças será relatado a seguir: um sobrinho (afilhado de 4 anos de idade), desde quando nasceu, foi orientado pelos adultos de sua família a utilizar a palavra "dindo" para a comunicação com o seu tio. O intuito seria evidenciar o laço que fora definido de "apadrinhamento afetivo entre tio e sobrinho". Com os passar dos anos, a criança se habituou com a forma de tratar "dindo" e sempre a reproduziu durantes as relações e interações familiares. Em um episódio, o referido tio ligou para a casa de sua irmã (mãe de seu afilhado) e em conversa com a mesma por telefone, percebeu que a criança estava próxima e então disse que estava com saudades da criança e perguntou como ela estava. A mãe então indagou: 
"seu afilhado está aqui, dando muito trabalho...". A criança, ao ouvir a mãe utilizar a palavra "afilhado", perguntou: "o que é afilhado mãe?". Ou seja, apesar de a criança utilizar a referência "dindo" em uma possível aquisição da linguagem dos adultos, este conceito de apadrinhamento ainda não estaria "generalizado". Ou seja, por mais que o afilhado reconheça o seu padrinho (independentemente da palavra utilizada), ao ouvir a referência em outro contexto (por exemplo a sua mãe evidenciando outro padrinho da família), poderia haver uma confusão no sentido de a criança acreditar que a mãe estava citando o "seu dindo". Talvez, o que se teria neste momento, se configuraria como um elo próximo do conceito (em geminação), ou um "pseudo-conceito" em transição.

A transição entre o pensamento por complexos e o pensamento por conceitos passa despercebida à criança, porque os seus pseudo-conceitos já coincidem no seu conteúdo com os conceitos dos adultos (VIGOTSKI, 2001, p. 71).

E continua mais adiante:

Para lá dos processos primitivos de pensamento dos sonhos, o adulto desviase constantemente do pensamento conceptual para o pensamento concreto do tipo dos complexos. A forma transitória do pensamento,o pseudo-conceito, não se limita ao pensamento das crianças; também nós recorremos a ela muito freqüentemente na nossa vida de todos os dias (VIGOTSKI, 2001, p. 77).

Ou seja, não só as crianças, mas os adultos também experimentariam o movimento do complexo pseudo-conceito a conceito, num incessante movimento que faz parte da vida do ser humano. Por fim, a "última fase" em relação a formação de conceitos, estaria vinculada a abstração, análise, unificação e separação "de seus elementos", a possibilidade de movimentação de "conceitos potenciais" a "conceitos genuínos":

Os processos que conduzem à formação dos conceitos desenvolvem-se segundo duas trajetórias principais. A primeira é a formação dos complexos: a criança une diversos objetos em grupos sob a égide de um "nome de família" comum; este processo passa por vários estádios. A segunda linha de desenvolvimento é a formação de "conceitos potenciais", baseados no isolamento de certos atributos comuns. Em ambos os processos o emprego da palavra é parte integrante dos processos genéticos e a palavra mantém a sua função orientadora na formação dos conceitos genuínos a que o processo conduz (VIGOTSKI, 2001, p 82) (grifo nosso).

Entendemos que a palavra apresentaria importante papel, enquanto signo mediador para a construção de conceitos "em potencial". Em uma atividade coletiva (seja ela de ensino ou não), há a busca pela satisfação de uma ou mais necessidades, por meio de ações mediadas. 
Para tanto, instrumentos são produzidos e utilizados para uma maior "otimização" da atividade (trabalho). Os meios e conhecimentos produzidos durante o desenvolvimento de uma "atividade de trabalho", são compartilhados entre os envolvidos.

Com o passar do tempo, os conhecimentos vão se desvinculando "da prática", com possibilidades de permanecerem materializados nos objetos, fenômeno evidenciado por Marx e Leontiev no que é chamado de objetivação (grifo dos autores) (MOURA, SFORNI, ARAÚJO, 2011, p. 41).

Esses conhecimentos "materializados no objeto" poderão "ser disponibilizados" para outros grupos e ações coletivas, na forma de apropriações e significações. Engeström (1999), ao mencionar possibilidades de interação coletiva e apropriações, utiliza o termo "ciclo expansivo" (figura 10). A expansão se daria (durante o processo), pelo desenvolvimento de um novo motivo, objeto, ações e operações possíveis.

Para ilustrar as internalizações e externalizações, e comparar o referido ciclo com a ZDP de Vigotski, a figura abaixo foi reproduzida: "No nível dos sistemas de atividade coletiva, esse ciclo expansivo pode ser visto como o equivalente à zona de desenvolvimento proximal, discutida por Vigotski (1978) no nível da aprendizagem individual" (p. 34).

Figura 10: $\mathrm{O}$ ciclo expansivo

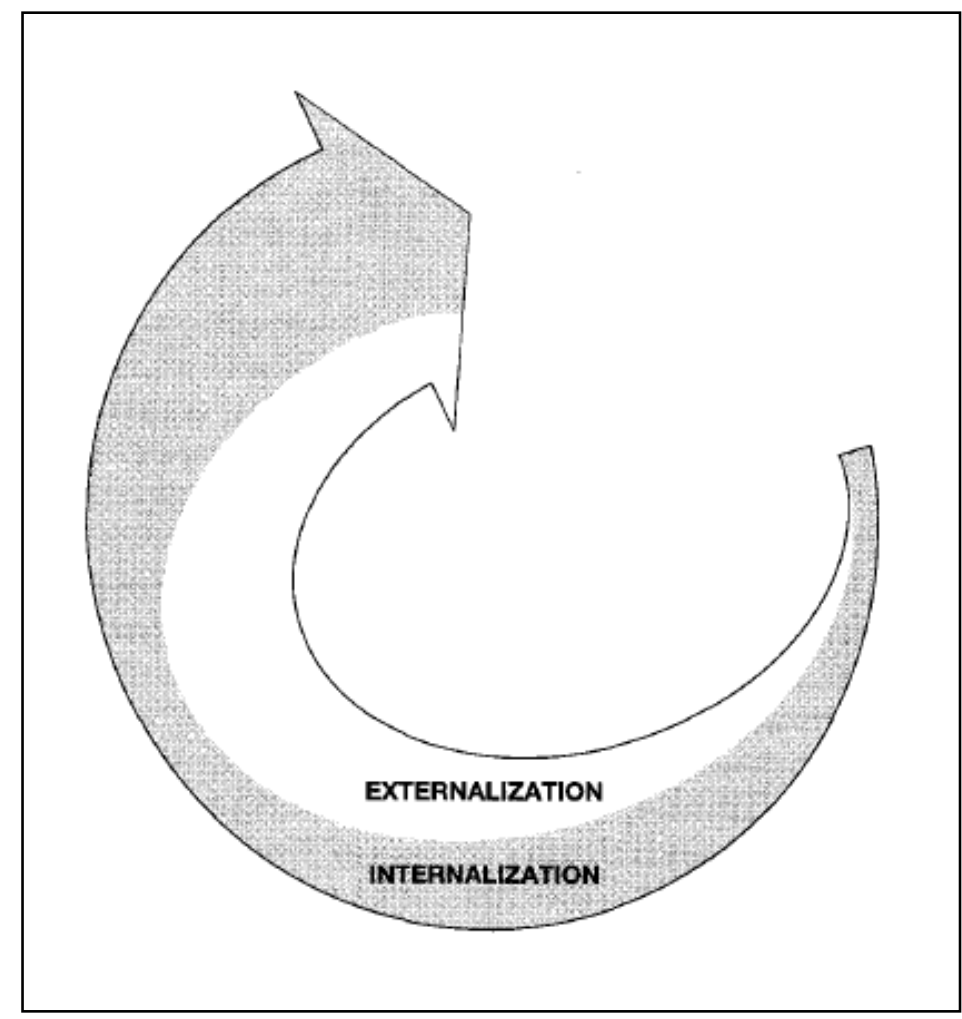

Fonte: Engeström(1999), p. 34. 
O ciclo expansivo de um sistema de atividades começa com uma ênfase quase exclusiva na internalização (...). A externalização criativa ocorre primeiro na forma de inovações individuais discretas. À medida que as rupturas e contradições da atividade se tornam mais exigentes, a internalização assume cada vez mais a forma de autorreflexão crítica - e a externalização, uma busca por soluções, aumenta. A externalização atinge o seu pico quando um novo modelo para a atividade é projetado e implementado (ENGESTRÖM, 1999, p. 34).

Nossa interpretação em relação a isso, influenciados por Engeström, é que os fenômenos de internalização e externalização experimentariam modificações (alternâncias) de "intensidades" durante o processo de construção dos conceitos (e/ou consciência sobre eles). Apesar de o nosso convívio social (externo) propiciar interações variadas, a internalização seria pessoal e intransferível, sendo esta a forma para o aprendizado "singular".

Essa constatação acerca dos processos referidos, viria ao encontro do que foi proposto por Vigotski (1981b), ao fazer uma alusão acerca destas possibilidades de externalização e internalização:

"É necessário que tudo interno em formas superiores fosse externo, isto é, para outros, era o que é agora para si mesmo. Qualquer função mental superior passa necessariamente por um estágio externo em seu desenvolvimento, porque é inicialmente uma função social. Isto é o centro de todo o problema do comportamento interno e externo... Quando falamos de um processo, "externo" significa "social". Qualquer função mental superior era externa porque era social a algum ponto antes de se tornar uma função interna, verdadeiramente mental "(VIGOTSKI, 1981b, p. 162 - tradução nossa).

Desta maneira, entendemos que "a ordem" possível para o desenvolvimento de uma função mental superior se daria do externo para o interno, do social para o individual. Em nosso curso EaD, o social e externo estariam evidenciados em uma plataforma digital, onde o convívio e as interações se estabelecem por meio das tecnologias. Os processos de internalização tangíveis (ou operações mentais internas), poderiam ser estabelecidos e a reprodução de uma possível apropriação estaria fadada as interpretações externas, por meio do que o aluno escreve (ou posta nas referidas plataformas) e os efeitos de interpretação e sentido dos demais participantes "leitores".

Essa consciência ou interpretação, foi evidenciada por Wertsch (1985), que pautado em Vigotski, argumentou que a consciência "de algo" se daria por meio da internalização de "situações" ocorridas no meio social, conforme trecho destacado a seguir: 
Vigotski via a internalização como um processo pelo qual certos aspectos dos padrões de atividade que foi realizada em um plano externo, vindo a ser executado em um plano interno. Ao contrário de muitos outros teóricos, no entanto, ele definiu atividade externa em termos de processos sociais mediados semioticamente e argumentou que as propriedades desses processos fornecem a chave para a compreensão surgimento do funcionamento interno (p. 62, tradução nossa).

Assim, faz-se necessário enfatizar a importância da mediação e seus efeitos de sentido para os processos de internalização. Destacamos novamente aqui, o fato de nossa pesquisa ter sido desenvolvida em um ambiente virtual e a responsabilidade dos envolvidos (professores, alunos, tutores, autores, mediadores, técnicos, designs instrucionais e outros), nos processos de mediação, compreensão e socialização dos fenômenos trazidos pelos alunos (como exemplos cotidianos), passíveis de movimentação a determinados conceitos científicos.

Para nos auxiliar junto as interpretações dos exemplos cotidianos trazidos pelos alunos (evidenciados nos resultados deste trabalho), faremos uma breve discussão, sobre os conceitos espontâneos e científicos de Vigotski.

\section{4 - CONCEITOS ESPONTÂNEOS E CONCEITOS CIENTÍFICOS (VIGOTSKI)}

Nos fóruns de discussão nos quais as AEs foram desenvolvidas, vários exemplos e possíveis conceitos cotidianos foram levantados pelos alunos. Eles trouxeram exemplos de seus amigos (trabalhadores de determinado lugar/empresa), exemplos de seus avós e seus próprios exemplos em situações cotidianas. Estes apontamentos foram importantes por darem indícios de situações cotidianas que teriam potencial para abordagem de conceitos científicos.

Porém, acreditamos que nestes fóruns, as intervenções do pesquisador teriam apresentado determinado caráter de educação sistematizada. A movimentação entre conceitos espontâneos e não espontâneos (dentre eles o científico), também foi evidenciada por Vigotski, como importante junto ao desenvolvimento de determinado conceito.

Os processos de desenvolvimento dos conceitos espontâneos e não espontâneos estariam relacionados e dotados de influência constante (um ao outro), uma vez que fazem parte de um processo maior e único, que é o desenvolvimento da gênese do conceito (VIGOTSKI 2001).

Ao citar que o conceito é constituído por condições externas e internas variáveis, remetemos mais uma vez aos processos de externalização e internalização. Mas seria possível definir os conceitos espontâneos e científicos? 
Ao operar com os conceitos espontâneos, a criança não tem qualquer consciência desses mesmos conceitos, pois a sua atenção se encontra sempre centrada no objeto a que o conceito se refere e nunca no próprio ato de pensamento (VIGOTSKI 2001,p. 92).

E faz a seguinte referência aos conceitos científicos :

Nos conceitos científicos que a criança adquire na escola, a relação entre esse conceitos e cada objeto é logo de início mediada por outro conceito. Assim, a própria noção de conceito científico implica uma certa posição relativamente aos outros conceitos, isto é, um lugar num sistema de conceitos. Defendemos que os rudimentos da sistematização começam por entrar no espírito da criança através do contato que esta estabelece com os conceitos científicos, sendo depois transferidos para os conceitos cotidianos, alterando toda a sua estrutura psicológica de cima até baixo (VIGOTSKI 2001,p. 93).

Nossa interpretação acerca desta movimentação entre conceitos espontâneos (ou cotidianos) e os conceitos científicos (ou não espontâneos), é que a consciência é condição, premissa e produto para a generalização de determinado conceito. Assim, quando a criança ou estudante (no nosso caso), está transitando pelo campo de conceitos espontâneos, a sua atenção está mais voltada ao objeto (que é uma referência do conceito) e sem outras relações ou posições a outros conceitos.

A raiz do conceito espontâneo estaria vinculada a uma situação de confronto com um objeto ou situação concreta e no caso dos conceitos científicos, teríamos uma sistematização mediada em relação ao objeto. Assim, os conceitos científicos desenvolveriam-se "para baixo", no sentido de generalização dos conceitos cotidianos e os conceitos espontâneos desenvolveriam-se para cima, por meio da abstração dos conceitos científicos. (VIGOTSKI, 2001).

Ao se entrar no "campo dos conceitos escolares" ou científicos (uma vez que o conhecimento científico não estaria vinculado a Escola unicamente), o indivíduo experimentaria a relação entre o objeto e demais conceitos inerentes, de forma mediada e possivelmente sistematizada. Esta relação ainda favoreceria a correlação dos referidos conceitos científicos "apreendidos" com os conceitos presentes em seu dia-a-dia (ou conceitos espontâneos).

A formulação a seguir, extraída de Sanchez (2014), foi elaborada na tentativa de exemplificar os conceitos espontâneos e científicos:

Os conhecimentos espontâneos podem ser desenvolvidos por meio de interações diversas e de forma empírica. O "galinho do tempo", que foi muito utilizado pelos mais "antigos", é um objeto que muda de coloração (de azul para rosa), quando o tempo está mais 
úmido (traduzido aqui como previsão de chuva). Este dado poderia ser considerado espontâneo, seja pela experimentação do indivíduo com o objeto concreto, seja pelas interações e socializações com os mais velhos. Assim, este conceito espontâneo, poderia movimentar-se a "científico" (de baixo para cima), se em uma aula tradicional, o indivíduo se apropriasse de símbolos e generalizações teóricas, bem como da linguagem científica inerente a este fenômeno. Então, se este conhecimento fosse estabelecido como científico, poderia ainda movimentar-se para de forma inversa (de cima para baixo), com possibilidades de generalizações. Desta forma, se foi possível a obtenção do conhecimento científico, no que diz respeito a hidratação de sais de forma geral, de acordo com sua natureza e com o meio que estão inseridos, poderia percorrer o caminho conceitual inverso (do teórico ao caso particular concreto - de cima para baixo) e inferir uma possibilidade de explicação. No exemplo trazido, o galinho do tempo é um objeto revestido por um sal de cobalto II, que apresenta a coloração azul em sua forma desidratada e coloração rosa, em sua forma hidratada, uma referência ao tempo mais úmido em dias chuvosos (SANCHEZ, 2014).

Nesta tese, alguns exemplos foram trazidos pelos alunos e apresentados no fórum de discussão como possibilidade desta movimentação entre conceito espontâneo e científico. Estes exemplos foram selecionados e serão retomados nos resultados e discussão. Entendemos que a mediação é peça chave junto ao desenvolvimento desta movimentação entre conceitos, principalmente em um curso EaD. Assim, apresentaremos a mediação à partir de Vigotski (1978) e Feuerstein (1990).

\section{5 - MEDIAÇÃO E O PROCESSO DE APRENDIZAGEM}

Como citado anteriormente, a mediação seria considerada a mola propulsora para o desenvolvimento ou construções conceituais em um curso EaD. A ferramenta disponibilizada como "meio de interação", por exemplo, o fórum de discussão no formato de AE, os textos variados, as postagens e outros artifícios, não produziriam, por si só, possibilidades de formulação conceitual.

A mediação seria possível se a interação entre sujeito, objeto, símbolos e meio, fosse constituída. Um mediador em potencial, teria a habilidade de seleção, direcionamento e interpretação do objeto durante o processo a ser mediado.

Uma criança possui várias experiências práticas e sensoriais durante o seu desenvolvimento, porém nem tudo que ela aprende se dará por meio da exposição direta ao objeto ou estímulo. Na verdade, na maioria das vezes, haverá determinada mediação de seus 
pais, responsáveis ou de qualquer outro "adulto". Estes, contribuem junto ao processo de aprendizagem mediada, ao se inserirem entre os estímulos e a criança. Uma criança descobrirá que inserir o dedo em uma tomada "dá choque" se experimentar sensorialmente ou se ouvir seus pais alertarem sobre esta possibilidade. Há determinada diferença entre estímulos e objetos:

[...] Ao contrário dos estímulos, os objetos não são dados: eles são "construídos". A construção de objetos torna-se possível somente porque os estímulos do meio ambiente assumem certos significados no curso da atividade humana, que é social em sua natureza (KOZULIN e PRESSEISEN 1995, p. 68) (tradução nossa).

Desta maneira, a criança poderia ter o estímulo "choque" e não mais inserir o dedo na tomada, ou poderia ainda objetivar esta condição por meio da experiência humana acumulada. Assim, a mediação enquanto condição humana, funcionaria como um veículo para uma possível apropriação, por serem portadores de símbolos e significados.

Nesse sentido, Kozulin e Presseien (1995), evidenciaram, na perspectiva de Vigotski (1978) e Feuerstein (1990), a "experiência da aprendizagem mediada", do inglês "Mediated Learning Experience" (MLE), como possibilidade de aprendizagem por meio de uma interação mediada entre as crianças e os estímulos ambientais, com a interposição intencional de um adulto (adulto interposto entre estes estímulos e a criança).

Ressaltaram que,

o objetivo final da aprendizagem mediada é tornar a criança sensível à aprendizagem através da exposição direta a estímulos e desenvolver na criança pré-requisitos cognitivos para tal aprendizagem direta. [...] Nem toda interação envolvendo uma criança, um adulto, e um objeto leva ao MLE (KOZULIN e PRESSEISEN 1995, p. 69-70) (tradução nossa).

Ou seja, temos possibilidades de interação que não levariam a aprendizagem mediada, mesmo com os requisitos ou estímulos citados. Para tanto, os autores apresentaram algumas condições acerca da intencionalidade/reciprocidade, transcendência e o significado da MLE.

No que diz respeito a intencionalidade e reciprocidade, a contribuição do adulto mediador estaria na possibilidade de conferir intencionalidade a ação interativa, que antes era não intencional, com um foco no objeto e outro na criança (ou indivíduo). Algumas características do objeto são alteradas pelo adulto, para que o objeto seja experimentado e não apenas registrado de forma passiva pela criança. De outra maneira, não seria o objeto o foco da interação mediada, mas sim os processos cognitivos da criança. Numa situação de aprendizagem, o aprendiz precisaria relacionar que o objetivo real da atividade de 
aprendizagem não é uma tarefa (ou atividade) particular, mas as próprias operações de pensamento em relação a este. Para a transcendência, os autores afirmam que, na MLE, há uma natureza transcendente da aprendizagem, independentemente do assunto ou conteúdo específico da interação. Assim, seria possível um ampliação ou generalização para uma gama de outras situações ou atividades. No que diz respeito ao significado, A MLE torna-se possível somente quando estímulos, ou informações são disponibilizados com significado pelo mediador. Se o evento se tornar uma simples sequência de atos comportamentais, desprovida de propósito e investimento afetivo, a situação perderia o potencial de mediação. É por isso que a teoria MLE é absolutamente incompatível com certos princípios comportamentais e práticas que deixam o significado para além da esfera da análise psicológica. Intencionalidade, transcendência e significado constituem o parâmetros básicos e necessários de qualquer interação MLE (KOZULIN e PRESSEISEN, 1995).

Interpretamos que na $\mathrm{AE}$ desenvolvida no espaço virtual, algumas condições de aprendizagem mediada poderiam estar presentes. Entretanto, temos a consciência que as referidas condições (alunos, professores, materiais, postagens, leituras, feedbacks, etc) não assegurariam a possibilidade de uma mediação para a aprendizagem de conceitos. Em alguns momentos a interação poderia ter sido estabelecida, sem a significação ou objetivação necessária a construção conceitual.

De outra maneira, é importante destacar a importância do mediador na elaboração de postagens com determinado significado, para a possibilidade de acesso a MLE. Para interações desprovidas desta significação, a atividade perderia o potencial de mediação.

\section{METODOLOGIA}

\section{1 - METODOLOGIA DE PESQUISA}

Esta pesquisa foi desenvolvida por meio de uma metodologia qualitativa (BOGDAN e BIKLEN, 1994), cujas principais características são a investigação descritiva e análise dos dados de forma indutiva com relevância à perspectiva dos participantes.

$\mathrm{Na}$ investigação qualitativa, é comum a utilização de equipamentos de áudio, vídeo, anotações de campo, transcrições, observações, entrevistas e etc. Em nosso trabalho, Atividades de Ensino (AEs), organizadas nos moldes de uma Atividade Orientadora de

Ensino (AOE), foram produzidas para que pudessem ser utilizadas nos "Fóruns de 
Discussão", de uma plataforma digital do curso EaD de Licenciatura em Ciências (Ambiente Virtual de Aprendizagem - AVA).

Assim, o material obtido para análise, é proveniente destes fóruns de discussão, onde as postagens dos alunos e pesquisador foram registradas contendo informações sobre o emissor da postagem, bem como o dia da semana, do mês e horário do apontamento, como o exemplo abaixo:

\section{Re: Fórum da semana " $x "$}

por "Fulano de tal" . - segunda, 10 Ago 2015, 23:41

Por se tratar de uma ferramenta de registro digital e de acesso compartilhado (onde cada indivíduo participante efetuou a sua postagem), os dados obtidos poderiam ser considerados mais fidedignos.

Em uma pesquisa qualitativa, as anotações de campo são comuns, e os materiais registrados mecanicamente costumam ser revistos pelo pesquisador (BOGDAN e BIKLEN, 1994).

Os investigadores qualitativos frequentam os locais de estudo porque se preocupam com o contexto. Entendem que as ações podem ser melhor compreendidas quando são observadas no seu ambiente habitual de ocorrência. Os locais têm de ser entendidos no contexto da história das instituições a que pertencem. Quando os dados em causa são produzidos por sujeitos, como no caso de registros oficiais, os investigadores querem saber como e em que circunstâncias é que eles foram elaborados. Quais as circunstâncias históricas e movimentos de que fazem parte? Para o investigador qualitativo divorciar o ato, a palavra ou o gesto do seu contexto é perder de vista o significado (BOGDAN e BIKLEN, 1994, p. 48).

Desta maneira, entendemos que os nossos fóruns de discussão se aproximariam desta "modalidade de registro oficial", cujas postagens produzidas pelos sujeitos participantes seriam influenciadas pelo contexto histórico dos mesmos, bem como pelas circunstâncias em que as postagens foram elaboradas e os seus processos de desenvolvimento. Isso porque, "Os investigadores qualitativos interessam-se mais pelo processo do que simplesmente pelos resultados ou produtos" (BOGDAN e BIKLEN, 1994, p. 49).

Os fóruns poderiam permitir a discussão/interação entre alunos e professores, para que determinados conceitos fossem apreendidos. Acreditamos que este formato de Educação (a distância), poderia favorecer o desenvolvimento de discussões menos hierarquizadas. No Ensino tradicional presencial, talvez a hierarquia do conhecimento (professor-aluno) seja mais delineada. Todavia na $\mathrm{EaD}$, a figura do professor é de certa forma diluída nestas várias 
ferramentas virtuais disponíveis, abrindo espaço para "outras vozes", que se tornam menos tímidas no mundo virtual.

Acreditamos que com o passar das semanas nas quais as AEs foram desenvolvidas, a distância da relação "pesquisador-grupo de alunos" possa ter sido atenuada. Não podemos afirmar que esta interação foi estabelecida como uma relação do tipo "sujeito-sujeito". Todavia, por meio de uma "rede de pessoas", conectadas em uma plataforma digital, ações de intervenção e mediação puderam ser desenvolvidas pelos sujeitos, fato que favoreceu a confluência de saberes e condições históricas, conforme as temáticas foram sendo trabalhadas.

No desenvolver das discussões, alguns "exemplos do cotidiano" foram levantados e deram sustentação ao aporte popular que a pesquisa qualitativa reverbera. Como exemplo, podemos citar a informação trazida por um dos alunos, sobre a utilização de formas de alumínio com algumas gotas de limão ou vinagre para que a mesma não escureça. Este dado será retomado nos resultados. Assim, a mediação destes "exemplos" trazidos pelos alunos e consequente vinculação com o conhecimento científico, foi desenvolvida pelo pesquisador.

Entendemos que a apreensão acerca do processo no qual a pesquisa foi desenvolvida é contemplada nos pressupostos de uma pesquisa qualitativa, com vistas para uma "abordagem fenomenológica" e possível "interação simbólica". Com isso, os investigadores fenomenologistas tentam compreender o significado que os acontecimentos e interações têm para pessoas vulgares, em situações particulares (BOGDAN e BIKLEN, 1994, p. 53). Ainda segundo os autores,

$\mathrm{Na}$ base desta abordagem, compatível com a perspectiva fenomenológica, encontra-se a asserção de que a experiência humana é mediada pela interpretação. Nem os objetos, nem as pessoas, situações ou acontecimentos são dotados de significado próprio; ao invés o significado é-lhes atribuído (BOGDAN e BIKLEN, 1994, p. 55).

Cada atividade inserida na plataforma digital, propiciou o desenvolvimento de situações e interações características junto ao grupos e indivíduos participantes. Cada AE poderia ser considerada uma situação particular, em que os sujeitos foram inseridos e instigados à discussão, por meio da mediação (mais evidente) do pesquisador e menos expressiva por parte dos demais atores e materiais disponibilizados.

Estas situações careceriam de uma análise que também levasse em consideração os acontecimentos (durante o processo) e as possíveis interações. Neste ínterim, a análise microgenética se configuraria como potencial ferramenta de análise e utilização. 


\section{2 - ANÁLISE - MICROGENÉTICA}

Como citado anteriormente, desenvolvemos AEs, organizadas nos moldes de uma Atividade Orientadora de Ensino (AOE), que foram inseridas no AVA do curso de Licenciatura em Ciências EaD. Mais especificamente, as AEs foram introduzidas na forma de "fóruns" na disciplina de Química, que poderiam permitir a discussão e construção/apreensão de conceitos de forma coletiva.

Por se tratar de uma investigação intersubjetiva em uma plataforma digital, as minúcias acerca das postagens e questões semióticas dos grupos participantes são cruciais, e a busca por uma análise por unidades se fez necessária. Uma análise por unidades na qual os trechos extraídos dos fóruns de discussão evidenciariam as propriedades "de todo o grupo" em detrimento de cada elemento.

Assim, a análise microgenética contribuiu para que os dados fossem analisados considerando-se os processos de elaboração e as minúcias relativas ás interações.

De acordo com Góes (2000),

A visão genética aí implicada vem das proposições de Vigotski (1981, 1987a) sobre o funcionamento humano, e, dentre as diretrizes metodológicas que ele explorou, estava incluída a análise minuciosa de um processo, de modo a configurar sua gênese social e as transformações do curso de eventos. Essa forma de pensar a investigação foi denominada por seus seguidores como análise microgenética (p. 11).

E continuou mais a frente:

[...] essa análise não é micro porque se refere à curta duração dos eventos, mas sim por ser orientada para minúcias indiciais - daí resulta a necessidade de recortes num tempo que tende a ser restrito. É genética no sentido de ser histórica, por focalizar o movimento durante processos e relacionar condições passadas e presentes, tentando explorar aquilo que, no presente, está impregnado de projeção futura. É genética, como sociogenética, por buscar relacionar os eventos singulares com outros planos da cultura, das práticas sociais, dos discursos circulantes, das esferas institucionais. (p. 15).

Ou seja, fazer o uso da microgenética reverberaria na possibilidade de se analisar minúcias apresentadas no "movimento das discussões". Durante o desenvolvimento da AE, apontamentos, dúvidas, constatações, exemplos cotidianos (alguns grupos trouxeram exemplos de seus familiares/avós) e mediações foram "escritas" na forma de postagens dos referidos nos fóruns de discussão. 
Ao trazer a discussão para o cotidiano escolar, devemos levar em consideração as condições sócio-históricas em que a mesma foi produzida, bem como os efeitos de sentido que estas condições podem revelar. Os atos de interpretação não podem ser negados, pois os sentidos não são dados e dependem destas referidas condições de produção, arquivos e memórias que cada um possui e pode (ou não) acessar. Um professor (mediador/pesquisador) precisaria considerar as interpretações atribuídas pelos seus alunos ao desenvolverem determinada leitura.

Além da leitura dos fóruns de discussão, as referidas interpretações podem ser consideradas durante a escrita dos textos ou arquivos postados. Assim, faz-se necessário destacar a movimentação e não linearidade das produções/leituras e as possibilidades de acesso ao patamar intrapsíquico. Este movimento abre espaço para as mais variadas interpretações sem que uma conclusão estanque seja adquirida.

As possibilidades de movimentação do interpsicológico para o intrapsicológico, foi discutida também por Wertsch (1985), no sentido de "transições microgenéticas". Em seus estudos, foram analisados casos de interação entre mãe e filho, durante a montagem de um "quebra-cabeça", os quais foram documentadas algumas transições dentro da sessão do funcionamento interpsicológico ao intrapsicológico.

Para o referido autor, alguns fatores poderiam contribuir para esta possível "transição", a saber:

[...] a prontidão por parte da criança; disposição do adulto em transferir a responsabilidade estratégica para a criança; a utilização de "avaliações reflexivas" para informar a criança sobre o significado de seus comportamentos; a explicitação das diretrizes dos adultos, e a possibilidade da estrutura dialógica do funcionamento interpsicológico para ser dominado no plano intrapsicológico através da diferenciação de funções de linguagem (WERTSCH, 1985, p. 166).

Assim, a possibilidade de movimentação do interpsíquico para o intrapsíquico poderia ser favorecida por meio da "mediação" desenvolvida pelo adulto durante o "quebracabeça" em questão (interpretação nossa), destacada pelo autor supracitado como "transferência da responsabilidade estratégica", bem como uma avaliação do adulto acerca das tarefas e comportamentos desenvolvidos pela criança durante o processo.

Seguindo a constatação de Wertsch (1985), entendemos que em nossas AEs, essa movimentação seria possível, uma vez que o pesquisador/mediador dos fóruns de discussão procurou conferir responsabilidades aos indivíduos participantes, bem como a avaliação, 
reflexão, direcionamento/redirecionamento dos conceitos a serem trabalhados/construídos por meio da linguagem escrita das postagens (para o desenvolvimento inicial das "questões propostas" no meio interpsicológico).

Uma vez que determinada atividade é desenvolvida de forma satisfatória no meio coletivo, como se daria a sua transição para o individual? Esta possibilidade estaria vinculada, a possibilidade de um adulto (ou mediador/tutor) incentivar a participação ou independência no desempenho das atividades como um aspecto vinculado a socialização/interação.

Arns (1980) mostrou que o tempo e os procedimentos para incentivar o funcionamento independente pode variar muito, dependendo de fatores culturais e socioeconômicos, mas a transição é uma parte necessária da socialização em qualquer lugar. Por isso, é preciso lidar com os mecanismos específicos pelos quais a competência é incentivada. Um adulto geralmente não consegue fornecer uma explicação ou um conjunto de diretrizes e, em seguida, insistir que a criança começar a funcionar de forma independente. A natureza da transição é tipicamente mais sutil, gradual e complexa (WERTSCH 1985, p. 167).

Neste sentido, concordamos que a possibilidade de movimentação (inter-intra) estaria vinculada aos limites culturais, sociais e econômicos dos indivíduos participantes da atividade em questão e que esta transição está contida nos fenômenos de socialização. O aluno do curso EaD no qual desenvolvemos esta pesquisa, seria o co-responsável pela "sua transição interpsíquica", de forma paulatina e com elevado teor de complexidade.

\section{3 - METODOLOGIA DE ENSINO}

De forma geral, as atividades desenvolvidas em um curso de natureza virtual podem ser divididas em síncronas e assíncronas. As atividades síncronas são caracterizadas por desenvolvimento em tempo real, como chats, videoconferências, etc, no qual os participantes precisam estar conectados ao mesmo tempo. Já as atividades assíncronas permitem postagens em tempos diferentes, que contribuem para uma interação sem definição de horários e alinhamento de conexão. Como exemplo desta última, temos os fóruns, questões objetivas e dissertativas, mensagens internas, entre outras.

O fórum de discussão é uma ferramenta virtual assíncrona que permite a interação entre pessoas vinculadas a uma plataforma digital. Essa interação é geralmente norteada por um tema central ou mais temas a serem inseridos em seu desenvolvimento. Em nossa 
proposta, o fórum de discussão virtual foi apresentado na forma de uma Atividade de Ensino (AE), organizada nos moldes de uma Atividade Orientadora de Ensino (AOE).

Todavia, o histórico insatisfatório de participação dos alunos nestes fóruns de discussão, fez com que o pesquisador buscasse uma alternativa para instigar a participação.

Assim, decidimos vincular "questões avaliativas dissertativas" aos fóruns de discussão. Não era nosso objetivo produzir questões, mas esta prática de elaborar questões associadas ao "Fórum de Discussão" teve um propósito: instigar os alunos a participarem dos mesmos de forma mais efetiva (motivação inicial). Assim, os alunos precisariam se interar do assunto, construir argumentos para posteriormente responderem a atividade avaliativa.

Vale ressaltar que mais uma vez, acreditamos que foi possível o desenvolvimento de uma AE, na qual situações variadas (antes, durante e posterior a atividade, como a produção e vinculação de questões ao fórum), foram detectadas. As questões foram produzidas para instigar os alunos a visitarem o fórum de discussão, no qual a $\mathrm{AE}$ foi disponibilizada/desenvolvida.

Este fórum na forma de $\mathrm{AE}$ foi desenvolvido em 8 grupos (distribuídos em 7 cidades/polos diferentes do Estado de São Paulo). Os grupos foram nomeados pelas letras A, B, C, D, E, F, G e H. Os grupos G e H são provenientes da mesma cidade, mas foram subdivididos em dois devido ao maior número de alunos. A quantidade de alunos matriculados na disciplina de Química em cada polo está reproduzida no quadro abaixo:

Quadro 1. Polos e número de alunos matriculados.

\begin{tabular}{|c|c|}
\hline Polo/Cidade & Número de alunos \\
\hline A & 20 \\
\hline B & 10 \\
\hline C & 11 \\
\hline D & 16 \\
\hline E & 10 \\
\hline F & 9 \\
\hline G & 37 \\
\hline H & 21 \\
\hline
\end{tabular}

Fonte: site: www.licenciaturaciencias.usp.br 
Os fóruns de discussão (no formato de $\mathrm{AE}$ ) ficaram abertos durante duas semanas para que os alunos pudessem interagir entre si e com o pesquisador. A proposta inicial era de uma semana de duração. Com o aumento da participação a atividade foi prorrogada para mais uma.

Assim, ficou estabelecido que em cada semana que do fórum, haveria uma questão com o assunto coincidente, para que os alunos pudessem buscar no fórum, possibilidades de "resolução" das questões. Estas questões foram produzidas pelo pesquisador e supervisionadas pela professora responsável pela disciplina virtual da LC.

A partir de então, o pesquisador fez a seleção dos conteúdos a serem abordados na disciplina de "Química Geral" do LC, que possui a carga horária de 60 horas, distribuídas em 20 semanas (ofertada no segundo semestre do primeiro ano). A disciplina visa apresentar os conceitos fundamentais da Química e suas grandes áreas, contemplando assim vários conteúdos de físico-química, química analítica, bioquímica, inorgânica e orgânica. Os conteúdos foram selecionados devido a sua importância sócio-histórica e fazem parte da Química Analítica Qualitativa (QAQ). A seguir, serão destacados os três temas (relativos as 3AEs propostas), que serão relatadas a seguir.

\section{4 - ATIVIDADES DE ENSINO (AES)}

Como dito anteriormente, em nossa proposta, o fórum de discussão virtual foi ofertado no AVA na forma de uma Atividades de Ensino, inspiradas na AOE (MOURA, 1992). Todavia, as AEs seriam possibilidades mais amplas de intervenção, levando-se em conta as ações prévias à $\mathrm{AE}$, bem como as posteriores. Assim, foram feitas "três intervenções", em três semanas específicas na disciplina de Química do curso de LC:

AE-1: "Obtenção de Substâncias - Metais Pesados (MP)" (adaptação da AOE desenvolvida no mestrado do pesquisador $\left.{ }^{6}\right)$;

\footnotetext{
${ }^{6}$ AOE-mestrado presencial: Em trabalhos anteriores (SANCHEZ, 2014), desenvolvemos uma Atividade Orientadora de Ensino (AOE) para um curso presencial de Ciências, mais especificamente um curso de Licenciatura em Química. Os conteúdos abordados foram: solubilidade, separação e identificação de metais pesados. Participaram desta AOE presencial 23 alunos de um curso de Licenciatura em Química, regularmente matriculados na disciplina de Química Analítica Qualitativa. A AOE foi desenvolvida no $1^{\circ}$ semestre de 2013 e incluiu três encontros presenciais previamente acordados e inseridos no cronograma da disciplina. Os dois primeiros encontros foram desenvolvidos em duas aulas simples de $1 \mathrm{~h} 40$, para a discussão teórica acerca do tema central - metais pesados - e consequente método de identificação e separação dos mesmos. Nestes, os alunos desenvolveram uma proposta de rota de separação, pautados em uma notícia acerca da utilização de
} 
AE-2: "Cinética das Reações Químicas - Prazo de Validade dos Alimentos";

AE-3: "Soluções: Aspectos Qualitativos - Solubilidade do Alumínio em panelas e utensílios";

As AEs produzidas foram desenvolvidas em todos os polos (cidades) onde o curso é oferecido.

Para a adaptação da AOE-MP como AE-1 e produção das novas AEs, algumas reuniões (via Skype), foram feitas com a professora responsável pela disciplina de Química no curso de LC. Como a responsável é docente do Instituto de Química de São Carlos IQSC/USP, o Skype foi alternativa mais prática e em consonância com a realidade da Educação à Distância $(\mathrm{EaD})$. Na primeira reunião, a docente forneceu o cronograma da disciplina e os conteúdos a serem trabalhados durante as 20 semanas de aulas.

Além do fórum de discussão, a docente responsável deixou em aberto a possibilidade de produzirmos "questões avaliativas" abertas ou fechadas para as semanas selecionadas. Achamos importante auxiliar na produção deste material (questões avaliativas), mesmo que não sendo o foco de nossa pesquisa. Questões sobre os temas das AEs também foram inseridas nas avaliações dos alunos.

AE-1: Como o tema central desta semana referiu-se acerca da "obtenção de substâncias", "formas de apresentação da matéria"," misturas" e "separação de misturas", a adaptação trouxe questões que permeassem este conteúdo.

Para esta mesma semana, o tutor elaborou uma questão para ser publicada no AVA como avaliação. Como dito anteriormente, não era nosso objetivo produzir questões avaliativas. Mas o tutor teve a percepção de elaborar uma questão dissertativa vinculada ao "Fórum de Discussão", como forma de instigar os alunos a participarem deste fórum. Assim, os alunos precisariam ler o "Fórum" e se interarem do assunto para posteriormente responderem a atividade avaliativa.

metais em batons e brilhos labiais. O terceiro encontro foi desenvolvido no laboratório didático experimental, em uma aula dupla de $3 \mathrm{~h} 30$, na qual os alunos colocaram em prática a rota proposta, ao manipularem uma amostra fictícia dos cosméticos. Pôde-se verificar que a AOE proporcionou o estabelecimento de nexos entre informações e favoreceu a aprendizagem sobre metais pesados. 


\section{QUESTÃO 1 (vinculada a AE-1, ofertada na semana 3 do curso)}

Para esta questão, você deverá ler o texto disponível na Atividade "3.3: Fórum de discussão." Considere uma amostra fictícia de batom, com suspeitas de possuir os seguintes metais: chumbo, cádmio, cromo e alumínio. Seria possível separar e identificar esses metais? De que forma?

\section{$\underline{\mathrm{AE}-1}$}

Atividade 3.3: Fórum de Discussão

Data de Início: 13/08 às 08h

Data de Término: $20 / 08$ às $08 \mathrm{~h}$

Categoria de Avaliação: Atividade Participativa.

NOTÍCIA: "Estudo dos EUA alerta para índices de metais em batons e brilhos labiais

Pesquisa encontrou chumbo, cádmio e cromo em cosméticos analisados. Alguns componentes químicos estão relacionados a doenças como câncer. Pesquisadores da Universidade da Califórnia, nos Estados Unidos, analisaram 32 tipos diferentes de batons e brilhos labiais $e$ detectaram a presença de metais como chumbo, cádmio, cromo e alumínio em pequenas e grandes quantidades nesses produtos. O fato preocupa pois alguns desses componentes químicos constantemente são relacionados a doenças graves como o câncer. O estudo, divulgado nesta quinta-feira na revista "Environmental Health Perspectives", aponta a necessidade de maior regulamentação desses cosméticos no país, já que nos Estados Unidos não há uma lei específica sobre metais em cosméticos.

Foram analisados 8 batons e 24 brilhos labiais de 7 diferentes empresas. Os preços dos produtos variavam de US5,59aUS5,59aUS 24 e eram os mais usados por jovens, de acordo com estatística obtida pelos investigadores.

Segundo o estudo, em dez amostras das 32 analisadas, foram encontrados níveis de cromo acima do tolerável, se considerada a média diária de ingestão involuntária. Além disso, em 24 produtos havia presença de chumbo. Apesar do nível não ser considerado alarmante, sua presença preocupa devido à possível exposição a crianças."

Disponível em: <http://g1.globo.com/bemestar/noticia/2013/05/estudo-dos-eua-alerta-paraindices-de-metais-em-batons-e-brilhos-labiais.html $>$.

<http://ehp.niehs.nih.gov/wp-content/uploads/121/6/ehp.121-a196.pdf > (original em inglês).

Acessos em 10 de maio de 2013.

A notícia relatada acima evidencia alguns produtos bem conhecidos de todos, os batons e brilhos labiais. Esse tipo de maquiagem é rotineiramente utilizado por mulheres, homens e até mesmo por crianças.

\section{Questões orientadoras:}

- Você considera o batom uma mistura? Se sim, que tipo de mistura seria?Qual seria a composição deste produto?

- Lavar a boca com água é suficiente para a remoção do batom?Explique.

- Identifique no texto os metais citados e escreva seus símbolos. 
- Os metais encontrados no batom estão na mesma forma química daqueles representados na tabela periódica dos elementos?

- Você já leu o rótulo de produtos cosméticos que utiliza?

É importante destacar que para esta AE-1, disponibilizada em todos os polos/cidades de "A" a "H" em que o curso foi ofertado, o pesquisador em questão mediou (apenas) as discussões do polo em que estava inserido como tutor (polo/cidade "D"). Desta forma, nos resultados e discussão relativos a AE-1 aparecerão mais alunos identificados com a letra D: D1, D2, D3 e assim por diante.

Para as demais atividades AE-2 e AE-3, o pesquisador ficou responsável pela mediação de todos os polos participantes e desta forma, poderão ser apresentados alunos identificados com as demais letras de "A" a "H" (de acordo com a descrição do Quadro 1).

\section{QUESTÃO 2 (vinculada a AE-2, ofertada na semana 9 do curso)}

Para esta questão, você deverá ler o texto disponível na Atividade “9.2: Fórum de discussão."

No supermercado, na padaria ou em outras lojas de produtos alimentícios, são encontradas mercadorias com uma data de validade evidenciada. Por que os alimentos possuem "prazo de validade?”. Como são definidos esses prazos? Como eram conservados os alimentos antigamente? Justifique.

\section{AE-2:}

Atividade 9.3: Fórum de Discussão sobre Cinética

Data de Início: 19/09 às 08h

Data de Término: 26/09 às 07h 03/10 às 07h (Atividade Prorrogada)

Categoria de Avaliação: Atividade Participativa.

Neste fórum você irá discutir com seus colegas sobre o problema proposto a seguir. Responda às questões e interaja com seus colegas.

Atenção: Postagens contendo plágio serão desconsideradas.

NOTÍCIA: "Produto aumenta prazo de validade de alimentos atacados por bactérias e fungos"

Pesquisa iniciada em Minas no ano passado, a partir de uma substância natural isolada em laboratório, busca ampliar o tempo de prateleira de itens da panificação em mais de $50 \%$. $O$ produto desenvolvido e patenteado pela mineira Phoneutria Biotecnologia e Serviços Ltda. e pela Universidade Federal de Minas Gerais (UFMG) é resultado de uma reação enzimática (provocada por enzimas), foi batizado como PHT 436 e tem função antimicrobiana 
(substância que mata ou inibe o desenvolvimento de micro-organismos como bactérias e fungos).

Disponível

em:

<http://www.em.com.br/app/noticia/internacional/2015/05/04/interna internacional,643667/p roduto-aumenta-prazo-de-validade-de-alimentos-atacados-por-bacterias-e-fungos.shtml $>$.

Acesso em 28 de maio de 2015.

"O tempo é implacável”. Esta frase é comumente ouvida quando se encontra algum conhecido que não se via há anos, quando um alimento qualquer é deixado fora da geladeira ou simplesmente quando uma palha de aço é esquecida em uma pia molhada.

Para o fórum de discussão desta semana, há a seguinte situação hipotética:

- Uma família produtora de frutas está instalada em uma região onde a energia elétrica ainda não chegou. A sua única fonte de renda é a comercialização da produção junto aos povoados mais próximos. Devido ao calor intenso da localidade, muitas frutas se perdem no transporte e prejuízos são contabilizados.

Quais as relações do problema em questão com o conteúdo estudado na semana? Que proposta(s) você poderia fazer com o intuito de auxiliar esta família?

\section{QUESTÃO 3 (vinculada a AE-3, ofertada na semana 13 do curso)}

Para esta questão, você deverá ler o texto disponível na Atividade "13.3: Fórum de discussão."

Um professor de culinária, preocupado com as possíveis consequências de se utilizar panelas de alumínio durante o cozimento de alimentos, disse aos seus alunos: "Se comprarem panelas novas, fervam água nas mesmas antes da utilização!"e "Evitem cozinhar extratos de tomate nestas panelas". Qual explicação cientifica para estas orientações do professor? (Procure utilizar equações químicas em sua explicação).

\section{AE-3:}

Atividade 13.3: Fórum de Discussão sobre Soluções

Data de Início: $17 / 10$ às $08 \mathrm{~h}$.

Data de Término: $24 / 10$ às $07 \mathrm{~h}$ 31/10 às 07h (Atividade Prorrogada)

Categoria de Avaliação: Atividade Participativa.

Neste fórum você irá discutir com seus colegas sobre o problema proposto abaixo. Responda às questões abaixo e interaja com seus colegas.

Postagens contendo plágio serão desconsideradas.

NOTÍCIA: "Cozinhar em panelas de alumínio é perigoso" 
Sabe aquela panela de alumínio antiga, que você ganhou da sua avó? Pode usar sem medo: esse é mais um daqueles mitos sem pé nem cabeça. É verdade que as panelas de alumínio podem soltar partículas do metal, principalmente se forem de qualidade inferior. E é fato também que o acúmulo de alumínio (e outros metais) no organismo facilita o desenvolvimento de doenças degenerativas, como os males de Alzheimer e Parkinson. Mas a preocupação é desproposital. "Pesquisas provaram que a quantidade de alumínio liberada pelas panelas é muito pequena, incapaz de ter esse efeito devastador sobre a saúde", afirma Daniel Magnoni, cardiologista e nutrólogo do Hospital do Coração e do Instituto Dante Pazzanese, de São Paulo. Segundo estudo feito pelo Instituto de Tecnologia de Alimentos, em Campinas, alimentos preparados em panelas de alumínio contribuem com apenas $2 \%$ do limite máximo de ingestão diária do metal (1 miligrama por quilo de massa corporal), dose mais do que segura, na avaliação da Organização Mundial da Saúde (OMS)."

Disponível em: <http://super.abril.com.br/ciencia/cozinhar-em-panelas-de-aluminio-eperigoso>.

\section{Acesso em 16 de julho de 2015.}

A notícia relatada acima evidencia o metal alumínio de comum utilização em panelas, canecas e utensílios em geral. Independentemente se a quantidade liberada é prejudicial ou não a saúde humana, o fato é que há liberação de alumínio ao longo da vida útil das panelas.

Para o fórum de discussão desta semana, há as seguintes questões orientadoras:

- Qual a forma química do alumínio constituinte das panelas?

- Como é possível este metal ser liberado e em qual forma?

- Algumas famílias possuíam (ou ainda possuem) o costume de "arear" (polir) as panelas de alumínio. O que você acha desta prática?

Os dados apresentados neste trabalho foram obtidos na realização da AEs. As conversas foram extraídas dos fóruns de discussão, que fazem o registro dos horários e as datas de interação. Essa possibilidade assíncrona de discussão também seria um fator relevante nos resultados encontrados. Os nomes dos alunos foram substituídos pela letra de sua cidade de origem seguida por números, de acordo com a ordem em que foram participando na conversa.

Os diálogos obtidos na plataforma $\mathrm{EaD}$ e as anotações de campo foram analisadas e os resultados foram organizados em dois episódios:

Episódio I: mediação (do tutor, da linguagem, do recurso).

Episódio II: mobilização do aluno em direção a construção conceitual. 


\section{RESULTADOS E DISCUSSÃO}

Após uma análise geral dos diálogos registrados no desenvolvimento das AEs desenvolvidas na $\mathrm{EaD}$, alguns apontamentos puderam ser feitos.

Entendemos que a natureza social da interação na $\mathrm{AE}$ virtual é diferente. No ambiente virtual de aprendizagem, o maior número de interações se deu no sentido alunosprofessor e professor-alunos. As discussões aluno-aluno foram mínimas. Todavia, nestas interações virtuais alunos-professor, os alunos trouxeram mais experiências e exemplos do cotidiano, quando comparado com a experiência presencial (SANCHEZ, 2014). Na AOE desenvolvida no presencial, apesar de a natureza social (aparente) de interação ser mais efetiva, ou seja, professores-alunos e alunos-alunos, as questões trazidas foram menos cotidianas e ficaram centradas no conteúdo específico de separação analítica (conceitos científicos já estabelecidos no livro didático).

Ao analisar os diálogos estabelecidos durante as atividades de ensino, identificamos dois episódios de acordo com os objetivos desta pesquisa. Por serem longos, dividimos os episódios em trechos que possibilitassem discutir as temáticas: mediação e construção conceitual (Episódios I e II, respectivamente).

\section{EPISÓDIO I: MEDIAÇÃO (DO TUTOR, DA LINGUAGEM, DO RECURSO).}

Para a discussão, selecionamos alguns trechos da AE-1e AE-2, enquanto possibilidades para a reflexão sobre o papel da mediação em um curso EaD. Vale ressaltar que apesar da seleção ter sido feita com o foco na mediação, no pano de fundo das postagens, estão todos os conceitos que foram sendo construídos.

Fizemos uma sub-divisão do episódio I, para auxiliar na organização da discussão. Assim, a AE-1, "Obtenção de substâncias - metais pesados", foi nomeada como "EPISÓDIO I - PARTE A" e a AE-2, "Cinética das reações químicas - prazo de validade dos alimentos", foi nomeada como "EPISÓDIO I - PARTE B".

A mediação entre "sujeito" e "objeto" ou de toda ação humana, poderia ser considerada o cerne das atividades de aprendizagem (mediação semiótica ou pela interação com o outro) (MARTINS, 2012). 
De acordo com Martins (2012),

A mediação era vista por Vigotski sob os aspectos: signo, palavra e símbolo (grifo do autor). As contribuições dos autores M. Cole e J. Wertsch e Bruner conferem uma determinação mais ampla ou restrita, conforme o ponto de vista. Nas perspectivas de Vigotski e Leontiev, os conceitos de "meios mediacionais" e de "ação mediada"são essenciais para compreender o verdadeiro significado ou processo da aprendizagem. (p. 11).

A mediação pode ter influências significativas junto ao processo de aprendizagem, sendo considerados essenciais segundo os autores supracitados. Todavia, a mediação (por si só, enquanto "meio"), não produziria efeitos/possibilidades de construção. Como exemplo, podemos evidenciar o ambiente virtual, que dispõe de textos, vídeos, fóruns e ferramentas variadas. Porém, em nosso entendimento, a mediação seria possível se a interação entre sujeito, objeto, símbolos e meio, fosse estabelecida. Caso contrário, inviabilizaria a apreensão de qualquer conceito, mesmo sendo considerado um espaço de aprendizagem.

Assim, para o desenvolvimento da mediação, a interação professor-aluno, alunoaluno e os meios disponíveis é crucial. A interação dialética entre sujeito, objeto e "fator de mediação" seria requerida para que o processo ou objetivo fosse estabelecido.

Dada a natureza abstrata de nosso objeto de pesquisa, ou seja, aprendizagem de conceitos científicos, numa condição particular $(\mathrm{EaD})$, pode-se dizer que o AVA foi o local com potencial para que a mediação entre conteúdos e sujeitos pudesse ocorrer, tornando o objeto mais explícito.

Entretanto, estes ambientes, com todos os seus vídeos, textos, fóruns, atividades e formas de interação, de nada adiantariam se o aluno em si, não souber fazer o uso correto de suas ferramentas, assim como não souber utilizar o potencial humano disponível na estrutura $\mathrm{EaD}$, para também favorecer a mediação de seus estudos e aprendizagens. Na contemporaneidade, os meios digitais enquanto espaços possíveis para interação, seriam mediados também por signos, mas por meio de uma linguagem digital que está em constante transformação devido ao avanço imoderado das tecnologias.

\section{EPISÓDIO I - PARTE A: AE-1:OBTENÇÃO DE SUBSTÂNCIAS - METAIS PESADOS $(M P)$.}

Os trechos reproduzidos a seguir foram selecionados por evidenciarem a importância da mediação.

$\mathrm{Na} \mathrm{AE}-1$, foram apresentadas as seguintes questões para se iniciar a discussão: 


\section{TRECHO 1 (Episódio 1)}

Você considera o batom uma mistura? Se sim, que tipo de mistura seria? Qual seria a composição deste produto?

Lavar a boca com água é suficiente para a remoção do batom? Explique.

Identifique no texto os metais citados e escreva seus símbolos.

Os metais encontrados no batom estão na mesma forma química daqueles representados na tabela periódica dos elementos?

Você já leu o rótulo de produtos cosméticos que utiliza?

A primeira postagem da aluna D1 está reproduzida abaixo:

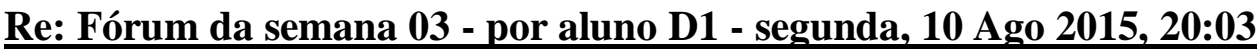

Olá pessoal! Boa semana de estudo a todos!

Pesquisando um pouco a respeito da química dos batons posso considerar:

1)O batom é uma mistura sim, homogênea creio eu. A maioria é composto por corantes, óleos, gorduras e ceras, que segundo a Legislação brasileira deve ser inócuo (que não causa danos à saúde) mesmo se ingerido.

2) Lavar a boca com água não é suficiente para a remoção pois no produto contém óleo, ceras e gorduras, que não se dissolvem apenas na água, a ideia seria utilizar algum produto com característica detergente.

No mesmo dia, antes de qualquer outra postagem, a aluna D1 fez a seguinte inserção no fórum:

\section{Re: Fórum da semana 03 - por aluno D1 - segunda, 10 Ago 2015, 20:09}

Em tempo:

Símbolos :

Chumbo: $\mathrm{Pb}$

Cádmio: $C d$

Cromo: $\mathrm{Cr}$

Alumínio: $A l$

Eu particularmente não tenho o habito de ler composição de produtos de beleza, tampouco modo de usar, reações adversas, etc.

Percebemos que a aluna D1 procurou responder as questões de forma "direta", chegando a enumerar as primeiras "respostas". Esta prática era esperada, e desta forma, o pesquisador fez a seguinte intervenção: 


\section{TRECHO 2 (Episódio 1)}

\section{Re: Fórum da semana 03 - por pesquisador - terca, 11 Ago 2015, 18:30}

Olá D1!

Parabéns pela participação.

Você disse acreditar que o batom é uma mistura homogênea. O que te levou a concluir isto?

Comentou que segundo a legislação brasileira este produto deve ser inócuo. Por que será que algumas marcas inserem metais na constituição do batom? Haveria alguma função/necessidade destas substâncias metálicas no batom?

Por que ao seu ver, "substâncias detergentes removeriam o batom"?

Com relação "a forma química" dos metais presentes nos batons. Seria a mesma forma que você evidenciou da Tabela Periódica (Pb, Cd, Cr e Al)? Ou seja, será que há Pb0 ou chumbo metálico no batom?

Por fim, você disse que não costuma ler os rótulos dos cosméticos. Procure dar uma olhada em batons seus ou de conhecidos, será que há algum metal evidenciado nesses rótulos?

Pessoal, essas questões também são para vocês oks?? Não apenas para a D1.

E então, o que acham?? Estou aguardando mais participações.

Abraços,

Pesquisador.

O pesquisador fez a opção de utilização de grifos em sua postagem (como destacado acima), pela necessidade de chamar a atenção para pontos importantes (em um texto não tão sucinto) e para a tentativa do diálogo com a aluna em questão e com os demais participantes do grupo.

No que diz respeito as possibilidades dialógicas no AVA, Martins (2012) ressalta que:

É relevante, também, o fato de que Bakhtin, ao comentar como o diálogo se processa, tanto na forma presencial quanto na virtual, afirma que a palavra nunca pertence ao falante, pois "metade dela pertence ao outro" (1998, p. 126). Assim, os docentes, no cotidiano, ao ensinarem seus alunos, devem levar em conta não apenas o que querem explicar, mas, também, ter ciência da percepção que os alunos têm do que lhes é ensinado. A recepção da fala do professor, por esses alunos, é feita de acordo com suas próprias maneiras de entender, as quais variam de aluno para aluno (p. 18, grifo nosso). 
Interpretamos o sentido do "virtual" atribuído pela autora (numa releitura de Bakhtin), como o que foi apresentado na introdução deste trabalho: "um virtual" que estaria no campo das potencialidades e que poderia ser transformado em real (articulado). $\mathrm{O}$ termo "virtual" é também aplicado para o ambiente de aprendizagem dos cursos EaD e traria consigo a importância impregnada deste "campo das potencialidades".

A autora ainda evidencia que no cotidiano da docência, faz-se necessário levar em conta as possibilidades de percepção dos alunos e este fato também vem ao encontro dos processos de internalização de Vigotski (que se daria de forma personalizada). Nos cursos EaD, a palavra escrita, vídeogravada ou em formato de áudio também poderia ser recebida de forma individualizada pelos alunos participantes. No caso de nossas AEs, apenas o recurso da escrita foi utilizado (entre pesquisador e alunos), fato que nos levou a focalizar em indícios de conceituação por meio das interjeições, exclamações, grifos em frases/textos elaborados pelos atores.

Assim, o pesquisador fez o uso da palavra escrita, para instigar a aluna ao desenvolvimento de possíveis conceitos em potencial, como a relação dos metais com o brilho do batom, possibilidades de remoção e especiação química dos metais constituintes.

Dando continuidade aos trechos reproduzidos, uma outra aluna fez a seguinte postagem abaixo da postagem do pesquisador:

\section{TRECHO 3 (Episódio 1)}

\section{Re: Fórum da semana 03 - por aluno D2- terca, 11 Ago 2015, 19:37}

O detergente removerá a parte oleosa do batom, mas os pigmentos acredito que não. Só demaquilante dos bons.

Os metais devem ajudar nessa fixação e deve ficar mais caro dependendo da proporção, por isso a diferença dos preços de batons. A marca " $X^{\prime \prime}$ tem uma linha que diz ter ouro na composição será?

Percebemos que os questionamentos da referida aluna foram pautados em experiências vivenciadas, como a utilização de demaquilantes, além da referida marca "famosa" citada por apresentar ouro na constituição de seu batom.

Para elucidar esta possibilidade de construção conceitual, por meio dos exemplos cotidianos, fizemos a seguinte síntese, representada na figura abaixo: 
Figura 11: Possibilidade de movimentação

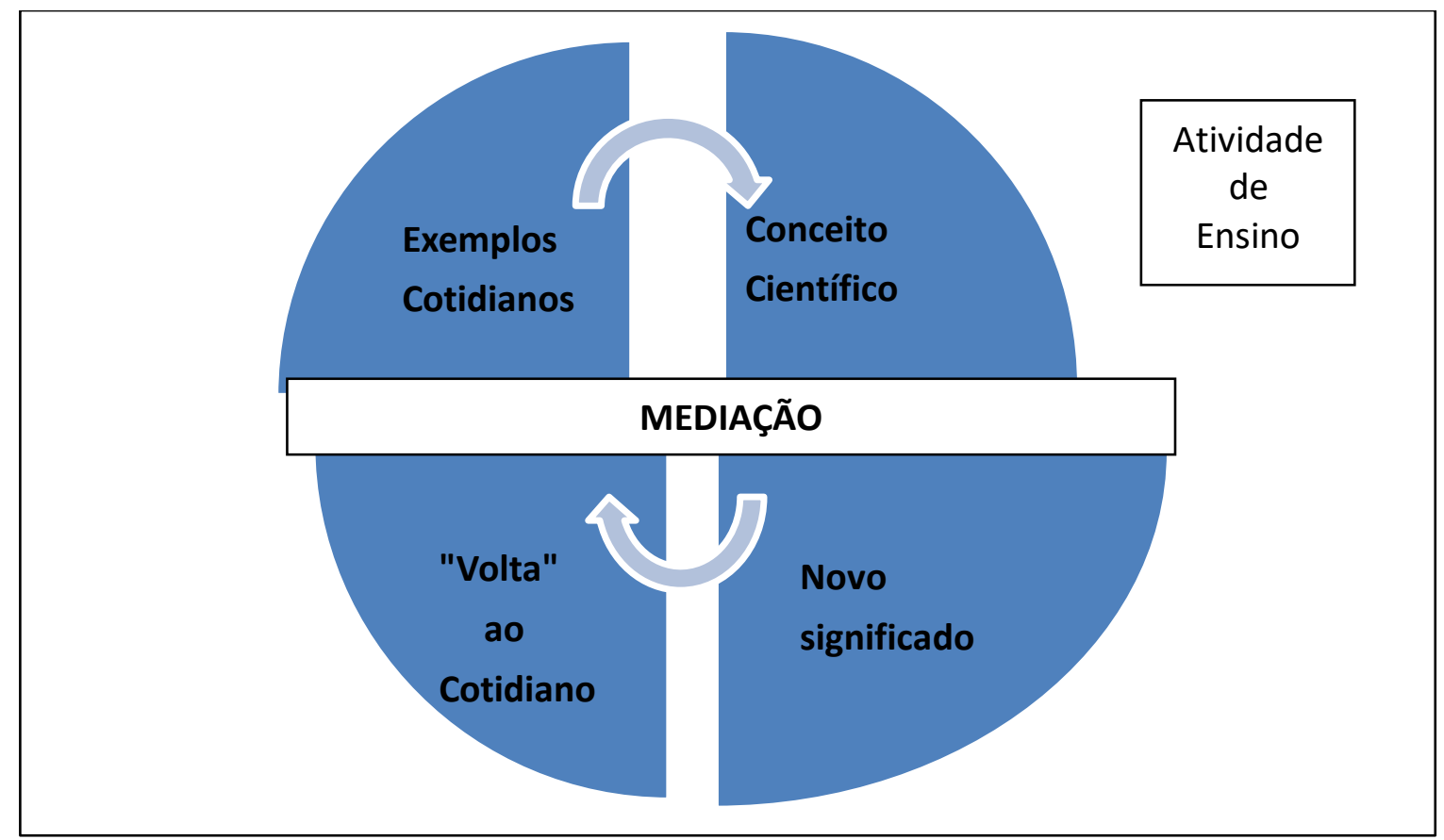

Fonte: próprio autor

Esta figura ilustra a Atividade de Ensino como pano de fundo para as situações conceituais vivenciadas em seu desenvolvimento. Após a disponibilização da AE no ambiente virtual, as discussões se iniciaram e os alunos trouxeram exemplos cotidianos, que foram discutidos, questionados e instigados à reflexão. Algumas generalizações foram possíveis, como a de que "semelhante solubiliza semelhante", fato que poderia ter propiciado uma nova significação, utilizada pela aluna ao retomar o seu dia-a-dia de utilização dos demaquilantes.

Assim, como veremos nos trechos seguintes, o pesquisador fez outra interferência na tentativa de mediar a reflexão sobre o fato de o demaquilante remover o batom e água (sozinha), não remover.

\section{TRECHO 4 (Episódio 1)}

Re: Fórum da semana 03 - por pesquisador - quarta, 12 Ago 2015, 08:00

Legal, D2!

Parabéns pela participação!

Você disse que os "demaquilantes bons" removem. Qual a composição desses demaquilantes? Por que será que algumas substâncias removem e outras não??

Fez referência a marca que diz "ter ouro na composição". Será que "esse ouro" pode ser uma mistura também? 
Neste momento, a aluna D1 fez uma nova postagem, para retomar as indagações do pesquisador:

\section{Re: Fórum da semana 03 - por aluno D1 - quarta, 12 Ago 2015, 15:02}

Vamos lá: Eu imagino que seja homogênea pois ao observarmos podemos ver apenas 1 fase. Eu acredito que substâncias detergentes removeriam o batom pois ele tem em sua composição além de corantes, óleo e cera. Quanto ao restante ainda não sei explicar =( estou pesquisando.....

Notamos, nesta postagem da aluna D1, a utilização de caracteres "=(" com o intuito de representações e efeitos de sentido. A utilização de caracteres ou "emojis"7é comum em um espaço digital. Na ferramenta AVA do curso em questão, os emojis não estão disponíveis para utilização. Assim, os alunos utilizam os caracteres como artifício.

Um outro ponto importante a ser destacado na postagem desta a aluna, é a necessidade revelada na última frase "ainda não sei explicar, estou pesquisando". Vale ressaltar que no referido momento, os alunos estavam na semana 3 do curso de Química Geral (3 semanas de um total de 20).

Assim, nas três primeiras semanas, já haviam sido trabalhos os seguintes conceitos na disciplina: Semana 1 - "Introdução aos Estudos da Química": O que é Química, níveis de representação, modelo, método e psicologia científica; Semana 2 - "Propriedades gerais das substâncias": densidade, massa, volume, pontos de fusão e ebulição, diagrama de fases e solubilidade; Semana 3 - "Obtenção das substâncias": formas de apresentação da matéria, misturas e separação de misturas.

Apesar da importância do protagonismo no aluno, ele não está sozinho e precisaria entender isto. Para tanto, o pesquisador fez a seguinte postagem:

\footnotetext{
${ }^{7}$ Emojis: palavra de origem japonesa, composta pela junção dos elementos $e$ (significado de imagem) emoji (significado de letra). Um pictograma ou ideograma - uma imagem que transmite a ideia de uma palavra ou frase.

Fonte: <https://www.significados.com.br/emoji/>. Acesso em 03 de julho de 2018.
} 


\section{TRECHO 5 (Episódio 1)}

Re: Fórum da semana 03 - por pesquisador - sexta, 14 Ago 2015, 22:27

Legal D1!

Com relação a remoção, o aluno $D 4$ fez uma postagem interessante mais abaixo:

"(...) solventes polares tendem a dissolver solutos polares, solventes apolares tendem a dissolver apolares" ...Ou seja, "semelhante, solubiliza semelhante".

Nesta abordagem, o pesquisador tentou orientar os alunos na leitura e interação com os demais participantes do grupo. Esta dificuldade de interação dos alunos entre si foi um dos maiores entraves. De forma geral, as interações se davam entre aluno-pesquisador, pesquisador-aluno.

Outro momento em que o pesquisador fez a mesma abordagem está reproduzido a seguir. Neste trecho, a aluna D5 havia concluído (de forma equivocada) que o batom é uma mistura heterogênea. Então o pesquisador fez a seguinte abordagem, na tentativa de instigar a discussão entre os demais participantes. Também retomou a pergunta sobre os "demaquilantes" feita para a aluna D2, até o momento sem resposta:

\section{TRECHO 6 (Episódio 1)}

\section{Re: Fórum da semana 03 - por pesquisador - quarta, 12 Ago 2015, 08:19}

Olá D5!

Parabéns pela participação.

Você disse que seria uma mistura heterogênea. Segundo o aluno D3 (postagem acima), seria uma mistura homogênea, pois visualizamos apenas uma fase.

E agora? Pautados em que podemos classificar uma mistura em homogênea ou heterogênea? Baseados na constituição da mistura ou nas fases observadas?

Sobre os "demaquilantes". Vou fazer a mesma pergunta que fiz para a D2. Qual a composição destes demaquilantes? Por que eles conseguiriam remover?

Disse que os metais não estão na mesma forma da tabela. ok. Qual forma estão estes metais então?

Então, após a indicação do pesquisador para a leitura/interação com outro participante que havia feito uma postagem acerca da mesma discussão (batom enquanto mistura homogênea ou heterogênea), a aluna D5, fez uma nova postagem com sua conclusão: 


\section{TRECHO 7 (Episódio 1)}

Re: Fórum da semana 03 - por aluno D5 - quinta, 13 Ago 2015, 21:00

De fato, podemos caracterizar o batom por uma mistura homogênea então por visualizarmos apenas uma fase, e não nos basearmos na constituição da mistura, pois, o batom possui mais de 300 componentes em sua formulação.

Já os demaquilantes conseguem remover totalmente o batom porque possuem óleos ou silicone em sua formula limpando melhor do que a água e sabão os resquícios de maquiagem (...).

Assim, após a referida intervenção do pesquisador, notamos que a aluna fez a leitura das demais postagens (sobre misturas do aluno D3, sobre demaquilantes da aluna D2), ao ponto de formular a "sua constatação".

Para Vigotski (1998),

O uso de meios artificiais - a transição para a atividade mediada -muda, fundamentalmente, todas as operações psicológicas, assim como o uso de instrumentos amplia de forma ilimitada a gama de atividades em cujo interior as novas funções psicológicas podem operar. Nesse contexto, podemos usar a lógica superior, ou comportamento superior com referência à combinação entre o instrumento e o signo na atividade psicológica (p. 73).

Assim, esta "situação mediada" sobre a utilização do demaquilante também foi evidenciada por outros alunos nas postagens posteriores, além da impossibilidade de remoção da maquiagem pela água (apenas). Este fato indicaria a possibilidade de leitura das postagens pelos demais participantes (e possível interação, significação):

\section{TRECHO 8 (Episódio 1)}

Re: Fórum da semana 03 - por aluno D6 - sexta, 14 Ago 2015, 09:41

(...) A água pura não remove o batom, precisa-se de um demaquilante ou sabão neutro, já que há presença de cera na composição. Não costumo reparar muito na composição das embalagens, poucas vezes faço isso.

A postagem da aluna G2 foi evidenciada a seguir, pelo fato de constar determinado conceito (ou pseudo) acerca da possibilidade de remoção do batom pelo demaquilante:

\section{Re: Fórum da semana 03 - por aluno G2 - sexta, 14 Ago 2015, 23:52}

(...) Demaquilantes são produtos que removem a maquiagem da pele, boca e olhos. A remoção do batom ou da maquiagem em geral, depende da polaridade química envolvida. A polaridade da água e do óleo e cera contidos no batom são diferentes, e uma máxima da 
química já diz que "semelhante dissolve semelhante", portanto para tirar o batom é necessário um demaquilante que também seja composto por óleo ou cremes (...).

\section{Re: Fórum da semana 03 - por aluno D7 - quarta, 12 Ago 2015, 14:54}

(...) Antes de saber desta publicação, nunca havia me atentado aos rótulos de maquiagens, em relação aos cosméticos como cremes, máscaras até que sim.

\section{Re: Fórum da semana 03 - por aluno D8 - quinta, 13 Ago 2015, 13:05}

(...) Lavar a boca somente com água não garante a remoção total do batom, é feita apenas a remoção superficial e visível aos olhos.

A discussão foi se tornando cada vez mais interessante, devido a situações trazidas pelos alunos. Na postagem abaixo, a referida aluna destacou a possibilidade de acesso das substâncias químicas dos cosméticos a corrente sanguínea. Esta abordagem foi utilizada pelo pesquisador para mediar a discussão sobre "a forma química" das substâncias nos referidos compostos.

\section{Trecho 9 (Episódio 1)}

Re: Fórum da semana 03 - por aluno D10 - sexta, 14 Ago 2015, 19:13

(...) Não. Lavar a boca não é o suficiente porque os metais já foram para a corrente sanguínea.

\section{Re: Fórum da semana 03 - por pesquisador - sexta, 14 Ago 2015, 22:44}

Parabéns pela participação D10!

Será que os metais vão direto para a corrente sanguínea? Qual a forma destes metais??

A aluna D10 não respondeu o referido questionamento, mas a aluna D11 entrou na discussão e fez a seguinte postagem:

\section{Re: Fórum da semana 03 - por aluno D11 - sábado, 15 Ago 2015, 03:54}

O Batom é uma mistura homogênea, apresenta uma única fase, quanto maior a fixação prometida, maior a sua composição de: muita cera, pouco óleo e alta concentração de pigmentos. Somente a água não elimina o batom, sendo necessários produtos químicos para sua retirada (...). Os metais são inseridos na composição para obtenção de variedade de cores. Não tenho o costume de ler rótulo da composição química dos produtos que compro; verificando agora constatei que não são mostrados na Composição os metais conforme a tabela periódica. Segue Composição: Demaquilante, conforme rótulo: Agua, ParaffnumLiquidum, Petrolatum; IsodecylOleate; PEG-40 Stearate; Stereth-2; CetylAlcohol; StearicAcid; Triethanolamine; PEG-4; DMDM Hydantoin; Carbomer; lodopropynylButylcarbamate. 
A postagem da aluna D11 foi importante para concatenar os assuntos até então discutidos. Por fim, o pesquisador fez a seguinte postagem geral, com os principais conceitos abordados:

\section{Re: Fórum da semana 03 - por pesquisador - terca, 18 Ago 2015, 12:57}

Parabéns pela participação D11!

Obrigado por trazer as informações contidas no rótulo de um "demaquilante". A aluna D6 encontrou que teria "Óleo essencial de YlangYlang, Disodium EDTA; Vitamina E Oleosa;"

Você trouxe que teria: "Agua, ParaffnumLiquidum, Petrolatum; IsodecylOleate; PEG-40 Stearate; Stereth-2; CetylAlcohol; StearicAcid; Triethanolamine; PEG-4; DMDM Hydantoin; Carbomer; lodopropynylButylcarbamate."Enfim, de maneira geral os demaquilantes são formados por compostos orgânicos: Hidrocarbonetos (Vaselina), álcoois, ácidos orgânicos e etc. Ou seja, para a remoção de substâncias que possuem "óleos e ceras" em sua constituição, é necessário utilizar compostos semelhantes.

Como discutido em resposta a uma postagem da aluna D1: "semelhante solubiliza semelhante". Em outras palavras, "compostos hidrofóbicos (que não interagem com a água), também denominados apolares solubilizam compostos apolares ou menos polares".

A água é uma substância muito polar e assim sendo, não seria suficiente para remover "por si só" o batom em questão.

As seleção dos trechos extraídos do fórum, foram reproduzidos neste episódio com o intuito de refletir acerca do papel do mediador no processo de construção coletiva em um ambiente virtual.

EPISÓDIO I - PARTE B: AE-2, CINÉTICA DAS REAÇÕES QUÍMICAS - PRAZO DE VALIDADE DOS ALIMENTOS.

Para o desenvolvimento da AE-2, foi apresentada a seguinte situação hipotética:

"Uma família produtora de frutas está instalada em uma região onde a energia elétrica ainda não chegou. A sua única fonte de renda é a comercialização da produção junto aos povoados mais próximos. Devido ao calor intenso da localidade, muitas frutas se perdem no transporte e prejuizos são contabilizados.Quais as relações do problema em questão com o conteúdo estudado na semana? Que proposta(s) você poderia fazer com o intuito de auxiliar esta família?" 
Faz-se necessário destacar que nesta semana 9 do curso de Química Geral, os alunos teriam contato com os seguintes conteúdos (concomitantemente ao desenvolvimento do fórum): "Cinética Química": velocidade das reações, teorias de colisão e estado de transição, fatores que influenciam a velocidade das reações;

Abaixo alguns trechos que compõem o Episódio 1 - Parte B,da discussão entre os grupos:

\section{Trecho 1 (Episódio 1)}

\section{Re: Fórum de Discussão - Semana 9 - por alunoB1 - quarta, 23 Set 2015, 13:11}

Sim, há uma correlação com o estudado essa semana, sobre cinética das reações, com o problema proposto nesse fórum. Da mesma forma que existem catalisadores em uma reação química, acelerando a reação, existem as substâncias inibidoras desses catalisadores, ou catalisadores competitivos entre si, inibindo uma reação. Os catalisadores biológicos, as enzimas, promovem as reações orgânicas, fazem o papel de catalisadores e inibidores no organismo e assim, uma boa ajuda seria auxiliar essa família, produtora de frutas, a se informar quanto a viabilidade do uso do PTH 436, ou de algum similar natural que não contivesse nenhuma toxidade e que o custo benefício tornasse o uso viável.

Se possível, a substância encontrada, inibiria as toxinas bacterianas que reagem com a fruta, protelando o processo de putrefação.

Re: Fórum de Discussão - Semana 9 - por pesquisador - quarta, 23 Set 2015, $\underline{20: 09}$

\section{Olá B1!}

Parabéns pela participação.

Além desta possibilidade do PTH 436, haveria mais alguma sugestão? E os demais colegas, o que acham??

Aproveitando o assunto: Vários alimentos podem ser comprados em lojas do ramo alimentício, supermercados e etc. Como será que é definido o prazo de validade destes alimentos?

\section{O que vocês acham??}

\section{Participem!}

Mais uma vez o pesquisador fez o uso de grifos, para enfatizar pontos a serem discutidos e instigar os alunos à leitura. Neste questionamento do pesquisador, o intuito era instigar a discussão de como se atribuiria o prazo de validade de alguns alimentos, vinculado ao conceito de cinética química. Logo após a indagação do pesquisador, foi feita postagem da aluna B1 e B2: 


\section{Re: Fórum de Discussão - Semana 9 - por aluno B1 - quarta, 23 Set 2015, 22:18}

Creio que os cálculos do prazo de validade se deem em função dos valores de velocidades das reações, embora, muitas vezes, percebo que estipulam um tempo "chutado", sério, creio que seja assim.

A postagem da aluna B1 evidenciaria a correlação do fenômeno com o conteúdo de cinética química. Mas seria necessário aprofundar um pouco mais a discussão, pois especificamente, de qual forma este prazo de validade dos alimentos seria estabelecido? Por qual ou quais técnicas? Por isso, logo a seguir, o pesquisador fez outra intervenção com o intuito de instigar esta abordagem conceitual.

\section{Re: Fórum de Discussão - Semana 9 - por aluno B2 - quinta, 24 Set 2015, 21:34}

Concordo, B1!!! Você expressou bem a atividade dessa semana. Gostaria de fazer um comentário do supermercado próximo a minha casa... colocam data de vencimento de uma semana para bolos e pães que você compra hoje, porém já comprei um bolo para levar para a faculdade para o nosso café num dia anterior, quando fui colocar na bolsa, estava embolorado... fiquei indignada e compreendi a má fé do mercado. Com o estudo da semana, percebi quão importante é a velocidade das reações químicas e a honestidade alheia :)

A postagem da aluna B2 foi interessante no sentido de vinculação de um exemplo cotidiano [...] "no supermercado perto da minha casa" [...]. Pela referida descrição, a aluna havia comprado determinado alimento "dentro do prazo de validade", mas que estragou ou "embolorou". Caberia ainda outras discussões acerca dos fatores que interferem na velocidade das reações, citado pela aluna no seguinte trecho "Com o estudo da semana, percebi quão importante é a velocidade das reações químicas"[...]. A aluna levantou um problema social que é a adulteração do prazo de validade visando lucrar mesmo que isso cause problemas de saúde e prejuízo a outras pessoas. Assim, o pesquisador elaborou a seguinte postagem, questionando possibilidades de conservação junto ao mercado citado pela aluna:

\section{Re: Fórum de Discussão - Semana 9 - por pesquisador - sexta, 25 Set 2015, 19:41}

Olá B1 e B2!

Muito legal a participação de vocês.

Vocês levantaram a hipótese de que alguns "estabelecimentos comerciais" estimam os prazos de validade (ou como disseram "chutam" uma data).

Vamos pensar mais um pouco...como poderíamos mensurar estes prazos? Que sugestões poderíamos dar ao supermercado próximo a casa da B2, no que diz respeito a conservação e também a data de validade a ser divulgada nestes alimentos?

Participem! 


\section{Re: Fórum de Discussão - Semana 9 - por aluno B1 - quinta, 1 Out 2015, 19:35}

Professor, colegas.

Então, nessa semana foi possível ler um pouco sobre ação de conservantes nas frutas, nos cárneos, nos laticínios, etc.

Existe de fato, uma variedade de conservantes e seus mecanismos de ação nos alimentos. Li de forma desorganizada, além de não dominar conceitos necessários a compreensão mais profunda dessas substâncias, não sendo possível ser seletiva com a imensidão de informações. Porém, nem que fuja um pouco desse fórum, tenho que salientar o meu fascínio pela substância quitosana. Conforme li, a quitosana é um copolímero constituído por unidades D-glicosamina. Faz parte de um grupo de derivados hidrossolúveis com inúmeras aplicações, dentre elas a conservação de alimentos. Possui atividade antimicrobiana, um número vasto de aplicações farmacológicas, em cosméticos, dentre outras áreas (...).

Interessante destacar esta última postagem da aluna B1, para a reflexão sobre o protagonismo discente e a importância da mediação. A aluna evidenciou a enorme quantidade de informações existes e a necessidade de certa "seleção" (que ela ainda não estaria apta a desenvolver). Sem dúvidas, em um curso $\mathrm{EaD}$, cujo acesso à Internet potencializa o contato com um grande número de dados, a mediação seria essencial junto à organização e direcionamento de ideias/conceitos.

\section{Trecho 2 (Episódio 1)}

\section{Re: Fórum de Discussão - Semana 9 - por aluno B1 - quinta, 1 Out 2015, 19:49}

Através de um amigo que é funcionário aposentado de um frigorífico, eu soube que em alguns frigoríficos, existe uma equipe de químicos contratados, com sede dentro da empresa, onde se dedicam a experimentos ligados à conservação dos cortes das carnes e seus derivados processados em indústrias.

Dentre as atividades desses profissionais, estão os cálculos ligados a velocidades de reações diversas, visando melhor adequação aos prazos de validade dos produtos. Ele destacou a luta pela inibição de salmonelas.

Bastante interessante, principalmente por "olhar" para um lado que nunca havia refletido.

Re: Fórum de Discussão - Semana 9 - por pesquisador - quinta, 1 Out 2015, $\underline{19: 55}$

Muito legal B1! 
A necessidade de conservação dos alimentos é histórico-cultural. Antigamente, esta conservação das carnes era feita pela secagem ou adição de sal, com o intuito de retardar o processo de deterioração desenvolvido por bactérias e fungos.

Ehoje??

Esta abordagem do pesquisador, foi feita com o intuito de se relacionar fatos históricos com o cotidiano e instigar a possibilidade de aprendizagem mediada. A aluna trouxe o exemplo de um frigorífico que possui químicos contratados para estudos e experimentação acerca da conservação das carnes. Mas e antigamente? Como as carnes eram conservadas?

Kozulin e Presseisen (1995), inspirados em Vigotski (1978) e Feuerstein (1990), definiram a experiência de aprendizagem mediada (do inglês Mediated Learning Experience MLE), como uma possibilidade de mediação reflexiva e a diferenciou de uma situação de interação direta com objeto:

$\mathrm{Na}$ situação direta, a criança interage diretamente com o meio ambiente. Essa interação pode tomar a forma de aprendizagem observacional, tentativa e erro, condicionamento, e assim por diante. Em qualquer caso, a criança interage diretamente com estímulos. Na situação de aprendizagem mediada, adultos ou colegas mais competentes colocam-se entre o ambiente e a criança, mudando radicalmente as condições da interação. $\mathrm{O}$ mediador seleciona, altera, amplifica e interpreta objetos e processos para a criança (KOZULIN e PRESSEISEN 1995, p. 67, tradução nossa).

Neste sentido, o papel do mediador/pesquisador, iria além de uma interação direta com as questões propostas na $\mathrm{AE}$ e alunos. Seria necessário refletir sobre as postagens elaboradas pelos alunos, selecionar trechos potenciais para possíveis construções a ampliações do conceito, como o caso relatado acima sobre a conservação dos alimentos na antiguidade.

A postagem abaixo (aluno B3) evidencia determinada "quebra" de raciocínio em discussão com as alunas B1 e B2. Porém a postagem do aluno está direcionada a temática central da discussão - o problema da conservação das frutas da família hipotética.

$\mathrm{O}$ assunto retratado a seguir, sobre os "jovens inventores" foi coincidente em mais de um grupo. Provavelmente, esta abordagem similar ocorreu devido ao fato de um programa da televisão aberta ter exibido uma reportagem sobre jovens que desenvolveram uma forma sustentável de conservação de frutas, por meio da utilização de cera de abelha. 


\section{Re: Fórum de Discussão - Semana 9 - por aluno B3 - sábado, 3 Out 2015, 00:36}

Olá!

No caso das frutas me lembrei dos três jovens do Rio Grande do Norte que fizeram experimentos no colégio e começaram a usar cera de abelha para conservar a produção da família. Eles retiraram as impurezas da cera, acrescentaram reagentes orgânicos e provaram através de diversos testes que a cera além preservar as frutas por mais tempo (mesmo não estando refrigeradas), não traz nenhum dano a saúde.

\section{$\underline{\text { Re: Fórum de Discussão - Semana } 9 \text { - por aluno C1- terca, } 22 \text { Set 2015, 22:00 }}$}

Caro professor e Colegas,

(...) A proposta do fórum me fez recordar de um quadro intitulado "Jovens Inventores" que assisti há algum tempo atrás. Nele, a ideia de três jovens estudantes foi divulgada. O projeto deles consistia em uma possível solução para o problema proposto. Os estudantes, moradores na região nordeste do país, tomaram conhecimento de uma técnica utilizada no Egito para conservação de corpos de faraós com cera de abelha, apresentada durante uma aula de História. Sabiamente eles aplicaram a mesma lógica a conservação das frutas produzidas naquela região. Na região onde moram, no estado do Rio Grande do Norte, a problemática não é a falta de energia elétrica, mas sim a seca que eleva ainda mais a temperatura da região.

$\mathrm{O}$ resumo trazido pelo aluno $\mathrm{C} 1$ foi interessante, por apresentar a importância da utilização e apropriação de conceitos históricos, possibilitando novas significações. Assim, a cera de abelha que havia sido utilizada pelos egípcios para a conservação de corpos (compostos orgânicos), poderia também ser utilizada para a conservação das frutas (também classificadas como compostos orgânicos).

Em seguida, a aluna C3 fez referência aos estudos da semana (da disciplina de Química), no que diz respeito aos fatores que influenciariam na velocidade das reações. Desta forma, este conceito também pôde ser trabalhado, sem que o pesquisador o apresentasse de forma expositiva ou descontextualizada:

\section{Re: Fórum de Discussão - Semana 9 -por aluno C3 - sexta, 25 Set 2015, 00:17}

Boa noite professor e colegas,

Como vimos no estudo dessa semana a temperatura está ligada à agitação das moléculas (energia cinética das reações), sendo assim, quanto maior a temperatura ou energia, maior será o grau de agitação e choque entre as moléculas, aumentando a velocidade de reação. 
Uma forma dessa família conservar seus alimentos, seria usando o processo de conservas, enlatamento por pressão, desidratação das frutas, ou, se pretenderem vender as frutas frescas, colhê-las antes de estarem maduras.

E apresentou uma possibilidade de conservação dos alimentos "em conserva", que foi questionada pelo pesquisador:

\section{Re: Fórum de Discussão - Semana 9 - por pesquisador - sexta, 25 Set 2015, 20:04}

Olá C3!

Parabéns pela participação. Produtos "em conserva" também é uma boa saída.

Para instigar um pouco mais: O que será que ocorre com as frutas (alimentos) quando são submetidos ao "processo de conserva"??

E os demais, o que acham destas possibilidades trazidas por C1, C2 e C3??

Este trecho evidencia a necessidade de mediação no que diz respeito a interação dos demais alunos entre si e ainda, a possibilidade de ampliação da discussão, por meio dos fatos/exemplos trazidos por eles mesmos. Assim, o comentário acerca do processo de conserva feito pelo aluno $\mathrm{C} 3$ e evidenciado pelo pesquisador, surgiu em outros momentos da discussão e também pôde ser trabalhado.

Desta forma, entendemos que a referida mediação se aproximaria da "experiência de aprendizagem mediada" (MLE), que seria possível quando estímulos, intervenções ou informações são apresentadas com significado pelo mediador/pesquisador:

\footnotetext{
Uma vez que o evento se torna uma mera seqüência de atos comportamentais, desprovido de propósito e investimento afetivo, a situação perde o seu potencial de mediação. É por isso que a teoria MLE é absolutamente incompatível com certos princípios comportamentais e práticas que deixam o significado para além da esfera de análise psicológica e modificação. Intencionalidade, transcendência e significado constituem os parâmetros básicos e necessários de qualquer interação MLE. (KOZULIN e PRESSEISEN 1995, p. 70, tradução nossa).
}

Ou seja, houve determinada intenção do mediador, para a orientação sobre como se daria a conservação das frutas em calda (exemplo trazido pelos próprios alunos, mas sem maiores explicações). A postagem abaixo, seguida da postagem do mediador trouxe uma possível explicação. Notamos que a formulação feita pelo aluno apresenta determinados termos "não científicos", como o relato de "paralisação das enzimas", mas também certo teor científico, ao utilizar a palavra "oxidação". Porém, também coube ao mediador/pesquisador selecionar os conceitos a serem trabalhados, de modo a contribuir para a manutenção do foco (cinética química). 


\section{Re: Fórum de Discussão - Semana 9 - por aluno C3 - sexta, 25 Set 2015, 21:58}

Boa noite, professor e colegas!

No processo de conserva das frutas, devido à alta temperatura da calda, há uma paralisação das enzimas responsáveis por sua deterioração, e quando as compotas são fechadas hermeticamente, evita-se sua oxidação.

\section{Re: Fórum de Discussão - Semana 9 - por pesquisador - quinta, 1 Out 2015,} $\underline{19: 23}$

Obrigado pelo retorno C3!

Realmente, os alimentos possuem enzimas que favorecem a degradação $e$ consequente mudança de características (evidência de reação química).

Como dito anteriormente, a possibilidade de "alimentos em conserva" também foi evidenciada em outros grupos:

\section{Re: Fórum de Discussão - Semana 9 - por aluno D1 - terca, 22 Set 2015, 22:00}

Boa noite!

Pesquisando sobre o tema proposto encontrei algumas informações interessantes, apesar de ainda não conseguir explicá-las quimicamente falando. Devemos verificar com quais frutas ele trabalha uma vez que a maça não deve ser armazenada próxima de outras frutas por emitir gás etileno que é responsável por acelerar o amadurecimento das frutas.

Se ele pretende vendê-las frescas é melhor mantê-las próximo a umidade.

Outras alternativas seria vender a fruta em forma de conserva e desidratadas (...).

Na postagem do aluno D1, são evidenciados traços de uma necessária abstração requerida ao se fazer a utilização da palavra (ou linguagem escrita).

Entendemos que pelo fato de o nosso trabalho ter sido desenvolvido em uma ferramenta virtual (fórum de postagens ou de discussão), cuja palavra escrita foi a principal forma de linguagem, o nível de abstração requerido exigiria uma libertação sensorial das "palavras verbalizadas" e substituí-las por "palavras escritas" (ou signos escritos).

A linguagem escrita é uma função lingüística distinta, que difere da linguagem oral tanto pela sua estrutura como pela sua função. Até os seus estádios mais elementares de desenvolvimento exigem um alto nível de abstração. É uma linguagem feita apenas de pensamento e imagem, faltandolhe as qualidades musicais, expressivas e de entonação, características da linguagem oral. Ao aprender a escrever, a criança tem que se libertar do aspecto sensorial da linguagem e substituir as palavras por imagens de palavras. Uma linguagem que é puramente imaginativa e que exige a simbolização da imagem sonora por meio dos signos escritos (isto é, um segundo grau de simbolização) terá que ser mais difícil para a criança do que a linguagem oral [...](VIGOTSKI, 2001, p. 98). 
O aluno D1 ao fazer o uso da palavra escrita, não teria sido claro acerca das possibilidades de utilização da água para conservação das frutas ou não. Verificamos que na mesma postagem, o aluno diz que "Se ele pretende vende-las frescas é melhor mantê-las próximo a umidade", ou seja, sugeriu a adição de água. E continua mais a frente, "Outras alternativas seria vender a fruta em forma de conserva e desidratadas". A palavra desidratada evidencia a remoção de água.

A utilização da palavra enquanto "signo mediador" seria de suma importância junto ao desenvolvimento da discussão no ambiente virtual, onde as "percepções" (no sentido físico-corporal dos indivíduos) não são passíveis de acesso.

Por meio desta mediação e de questionamentos do pesquisador que não traziam a resposta pronta e acabada, buscou-se orientar os indivíduos para a construção dos conceitos arraigados nas atividades desenvolvidas nesta pesquisa. A possibilidade de acesso a uma "zona de desenvolvimento potencial", levaria a mudança de patamar e consequente aprendizado.

Para Vigotski (1991),

A zona de desenvolvimento proximal define aquelas funções que ainda não amadureceram, mas que estão em processo de maturação, funções que amadurecerão, mas que estão presentemente em estado embrionário (p. 58).

Compreendemos que em um curso a distância, onde os questionamentos dos indivíduos são registrados em uma plataforma, há um tempo considerável para leitura e reflexão do pesquisador/professor e posterior "resposta" ao aluno. Assim, a mediação dos conceitos espontâneos trazidos pelos alunos, orientada ao acesso de um conceito científico na $\mathrm{EaD}$ é diferente, pois o professor tem mais tempo para reunir informação e estabelecer relações que sirvam para mediar o diálogo com o aluno. Há tempo tanto para o aluno quanto para o professor para consultar diferentes fontes, há tempo para elaborar melhor o pensamento, uma vez que a linguagem escrita exige uma organização daquilo que se vai dizer.

Assim, o pesquisador achou pertinente intervir acerca desta peculiaridade em relação a água e a conservação das frutas, como reproduzido a seguir: 
Re: Fórum de Discussão - Semana 9 - por pesquisador - quarta, 23 Set 2015, $\underline{07: 34}$

Olá D1!

Parabéns pela participação. Muito interessante as informações que você trouxe!

Uma dúvida:

Será que só a maçã produz o gás etileno que você comentou?? Sobre outras frutas, o que você acha??

E os demais colegas??

Você também falou da umidade. Muito legal!

Mas logo em seguida, citou a possibilidade de desidratá-las (perda de água).

E agora, qual seria o melhor método? Hidratar ou desidratar???

A aluna D1 não efetuou mais nenhuma postagem acerca da observação do pesquisador sobre as possibilidades de hidratação ou desidratação. Mas um outro aluno, mais adiante, fez a seguinte postagem:

\section{Re: Fórum de Discussão - Semana 9 - por aluno D2 - sexta, 25 Set 2015, 09:53}

Sim, uma das maneiras de conservar os alimentos por um período maior de tempo é a desidratação e beneficiamento a vaco. Por isso a importância de pequenas cooperativas para a agricultura familiar.

Assim, a melhor alternativa dependeria da necessidade vigente. A conservação por um período longo se daria pela remoção da água, uma vez que a mesma é importante junto ao processo de proliferação de fungos e bactérias. Mas para apresentação das frutas e venda imediata (sem longos períodos de armazenamento), a hidratação seria melhor indicada. Alguns fatores como temperatura, pressão e umidade influenciariam no processo de degradação.

Outros alunos, apresentaram postagens sobre o gás etileno, que também é um fator importante junto ao amadurecimento das frutas:

\section{Re: Fórum de Discussão - Semana 9 - por aluno D3 - quarta, 23 Set 2015, 10:15}

O etileno é um gás produzido pelas frutas que faz com que elas amadureçam. Manter essas frutas em ambiente fechado vai fazer com que a taxa de etileno produzido seja maior, aumentando a taxa de amadurecimento das mesmas (...), ou seja, a agricultura familiar necessitaria de uma pequena estrutura de cooperativa para construirem uma câmara fria para melhor conservação de alimentos. 
Re: Fórum de Discussão - Semana 9 - por pesquisador - quarta, 23 Set 2015, $\underline{19: 44}$

Olá D3!

Parabéns pela participação.

Você fez uma abordagem sobre o aumento da concentração do gás etileno em ambientes fechados e consequente amadurecimento das frutas.

Seria possivel retardar esse processo?

Re: Fórum de Discussão - Semana 9 - por aluno D3 - segunda, 28 Set 2015, $\underline{19: 05}$

Sim, desde que a temperatura seja mais baixa para retardar a produção de etileno.

Esta interação direcionada unilateral professor-aluno, foi importante no sentido de destaque para os fatores que poderiam aumentar ou diminuir a velocidade das reações. No caso dos gases, a temperatura mais elevada contribuiria para a sua difusão e como concluído pela aluna, a temperatura baixa teria efeito contrário. Daí a importância de se manter as frutas em temperaturas menores (como na geladeira por exemplo).

Porém, a referida interação se deu de forma menos pronunciada com os demais participantes do grupo e ficou no campo aluno-professor.

Neste sentido, as reproduções a seguir foram selecionadas com o intuito de apresentar uma interação entre os alunos um pouco mais pronunciada:

\section{Re: Fórum de Discussão - Semana 9 - por aluno E1 - quinta, 1 Out 2015, 21:54}

(...), durante todo esse tempo fiquei pensando em algo mais econômico e não achei nenhuma solução.

Qual seria uma boa solução para esse problema?

\section{Re: Fórum de Discussão - Semana 9 - por aluno E2 - sexta, 2 Out 2015, 10:54}

Bom dia!

Minhas sugestões para este produtor seria:

- uso dos tradicionais caixotes de madeira, que possuem vãos nas laterais, que melhoram a ventilação e evitam o aquecimento das frutas;

- controlar a data da colheita e deixar armazenado separadamente de forma que a entrega seja sempre das frutas que foram colhidas primeiro.

-aprimorar o treinamento dos funcionários no momento da colheita para evitar ao máximo que "machuquem" as frutas. Os locais que receberam algum tipo de choque mecânico estão propensos a iniciar o processo de decomposição e crescimento de bactérias.

- Evitar o transporte das frutas em horário de pico do sol. 


\section{Re: Fórum de Discussão - Semana 9 - por aluno E1 - sexta, 2 Out 2015, 20:29}

Uaua, E2!

Nem passou pela minha cabeça sugestões como essas. Muito bom!

$; D$

Uma aluna de outro grupo, trouxe uma possibilidade acerca do prazo de validade dos alimentos. Vale ressaltar ainda que a saudação "olá professor" apareceu algumas vezes, evidenciando o contato direcionado ao professor (no sentido aluno-professor). Assim, notamos que de forma geral, a interação aluno-aluno foi menos pronunciada, pois a maior parte da discussão ocorreu a partir da interação aluno-professor e professor - demais alunos.

Re: Fórum de Discussão - Semana 9 - por aluno G1 - domingo, 27 Set 2015. $\underline{22: 58}$

Olá, professor! Segundo o site da Anvisa, frutas e verduras frescas não precisam ter o prazo de validade estampado. Para determinar a validade dos alimentos embalados $e$ industrializados, as indústrias fazem testes para verificar sua degradação em diversas condições de temperatura e tempo.

Re: Fórum de Discussão - Semana 9 - por pesquisador - quinta, 1 Out 2015, $\underline{19: 00}$

Muito bom G1!

O prazo de validade é definido pelo fabricante, após testes de resistência e qualidade. Há um limite estabelecido pela ANVISA com relação a quantidade (tolerável) de microorganismos em cada classe de alimentos.

Por fim, o pesquisador fez a seguinte postagem, como "feedback geral":

Re: Fórum de Discussão - Semana 9 - por pesquisador - sexta, 16 Out 2015. $\underline{15: 18}$

Olá pessoal!

De forma geral, podemos concluir que os alimentos possuem enzimas que favorecem a degradação e consequente mudança de características (evidências de que reações estão ocorrendo). Assim, tais alimentos possuem um limite de tempo para serem consumidos, limite este onde as condições iniciais de coloração, odor, sabor são preservadas. Fatores como temperatura, pressão e umidade influenciam no processo de deterioração. A cinética química estuda a velocidade das reações, bem como os fatores que podem influenciar nesta velocidade. Em alguns casos é desejável que a reação se processe o mais rápido possível 
(produção industrial por exemplo). Porém, há situações que quanto mais lenta a reação, melhor (amadurecimento ou apodrecimento das frutas a serem vendidas).

o prazo de validade dos alimentos industrializados é definido pelo fabricante, após testes de resistência e qualidade. Há um limite estabelecido pela "Agência Nacional de Vigilância Sanitária" (ANVISA), com relação a quantidade (tolerável) de microorganismos em cada classe de alimentos.

Geralmente este prazo é estipulado com o intuito de se manter as características iniciais do produto, evitando-se que reações químicas ocorram e novos produtos sejam obtidos.

A necessidade de conservação dos alimentos é Histórico-Cultural. Antigamente, a conservação era feita pela secagem ao sol elou adição de sal, com o intuito de retardar o processo de deterioração desenvolvido pelas bactérias e fungos. Esta desidratação do alimento inviabiliza a proliferação de microorganismos.

Parabéns pelas discussões e sugestões!

Até o próximo fórum.

\section{EPISÓDIO 2. MOBILIZAÇÃO DO ALUNO EM DIREÇÃO A CONSTRUÇÃO CONCEITUAL.}

AE-3: SOLUCÕES: ASPECTOS QUALITATIVOS - SOLUBILIDADE DO ALUMÍNIO EM PANELAS E UTENSÍLIOS.

Para este episódio, selecionamos os dados obtidos da AE-3 - "Soluções: aspectos qualitativos - solubilidade do alumínio em panelas e utensílios". Faz-se necessário enfatizar que nesta semana do curso de Química Geral, os alunos teriam contato com os seguintes conteúdos (concomitantemente ao desenvolvimento do fórum): "Soluções": aspectos energéticos, dissolução, representação em meio aquoso eletrólitos, propriedades coligativas e osmose.

Nesta AE, foram apresentadas 3 questões orientadoras, reproduzidas a seguir:

Qual a forma química do alumínio constituinte das panelas? Como é possível este metal ser liberado e em qual forma? Algumas famílias possuíam (ou ainda possuem) o costume de "arear" (polir) as panelas de alumínio. O que você acha desta prática?

As referidas questões instigaram a discussão conceitual sobre a solubilidade do metal alumínio, que será evidenciada no episódio apresentado a seguir.

A discussão apresentada abaixo evidencia um exemplo do cotidiano trazido pelo aluno B3, acerca da prática de "ferver as panelas novas antes de serem utilizadas". 
Entendemos que esta postagem evidenciou o conceito espontâneo, que mediado pelo pesquisador poderia ser levado a um conceito científico:

\section{Trecho 1 (Episódio 2)}

\section{Re: Fórum de Discussão - Semana 13 - por aluno B3 - sexta, 23 Out 2015, 21:22}

(...) Ferver de 3 a 4 vezes quando são novas e não cozinhar ácidos nessas panelas, como massa de tomate, cebola, brócolis, couve entre outros, pois contém enxofre na sua composição, desprende partículas salientes da panela e evita absorver maiores quantidades do alumino pelo nosso organismo. Ainda deve se considerar usar colher de pau, pois de metal também ajudam a liberar alumínio, bem como arear a panela (...).

Vigotski (1989) abordou em seus estudos definições distintas para o que chamou de conceitos científicos e não científicos, pautado em seus respectivos processos de formação. Os conceitos denominados como científicos (ou escolares), podem ser representados pelo conjunto de fenômenos desenvolvidos por meio da ciência e articulados por alguma teoria científica. Assim, são caracterizados pela inter-relação consciente entre a abstração e a generalização. Neste, as instituições escolares desempenham papel fundamental (NUNEZ, 2009).

O exemplo a seguir foi elaborado com o intuito de retratar um possível momento deste percurso conceitual nas ciências naturais: Uma pessoa começa a desenvolver conhecimentos espontâneos, pautados em conversas informais e de forma empírica. Assim, sempre ouvimos dizer que o famoso "galinho do tempo", muda de coloração (de azul para rosa), quando há previsão de chuva. Este conhecimento pode ser considerado de natureza espontânea, seja pelo fato de se ter ouvido adultos relatando o fenômeno, seja pela própria experimentação sensorial da criança.

Assim, este conceito poderá servir de base analítica para a produção de conceitos "científicos" se, em âmbito escolar, o indivíduo desenvolver uma linguagem científica, apropriando-se de símbolos e generalizações teóricas, aos casos específicos. Os conceitos espontâneos poderiam ser levados a científicos (em um movimento para cima), por meio das abstrações, mediações, relações entre conceitos e tomada de consciência. Os conceitos científicos, por sua vez em um caminho inverso, poderiam ser generalizados (em um movimento para baixo), sendo afetados por condições externas e internas (VIGOTSKI, 2001).

Desta forma, o pesquisador continuou o questionamento: 


\section{TRECHO 2 (Episódio 2)}

Re: Fórum de Discussão - Semana 13 - por pesquisador - domingo, 25 Out

\section{$\underline{\text { 2015,17:03 }}$}

Olá B3!

Parabéns pela participação!

Você disse que 'Ferver de 3 a 4 vezes quando são novas e não cozinhar ácidos nessas panelas (...) evita absorver maiores quantidades do alumino pelo nosso organismo.'

Por que ferver? Poderia citar alguma equação química para relacionarmos esse fenômeno a diminuição de alumínio liberado?

E alimentos básicos, haveria algum problema?

Infelizmente, após esta última postagem do pesquisador não houve mais participações por parte dos alunos deste grupo. Talvez pelo fato de eles terem obtido a "resposta" para a "questão avaliativa" e por conseguinte, pelo fato de o "motivo desta ação" não ter coincidido com o seu objetivo.

Assim, o motivo para a participação deste "fórum" seria apenas a resolução das "questões", obtenção de nota, possível aprovação na disciplina e etc. (um motivo eficaz). O motivo acerca da construção do conceito químico de solubilidade do metal alumínio poderia não estar estabelecido e "apenas" uma ação teria sido delineada (em vez da atividade em si).

Para Leontiev, (2001, p. 69) "Um ato ou ação é um processo cujo motivo não coincide com seu objetivo, (isto é, com aquilo para o qual ele se dirige), mas reside na atividade da qual ele faz parte".

Assim, quando objeto e motivo são diferentes, temos o desenvolvimento de "ações". Para se ter uma atividade, objeto e motivo precisariam ser coincidentes. Desta forma, entendemos que esta ação não se configuraria (inicialmente) como atividade psíquica para os referidos alunos do grupo B, uma vez que o motivo seria apenas "responder" a questão. Se continuassem a participar da discussão, poderíamos inferir que estariam motivados pelo objeto e que o motivo da atividade estaria coincidindo com este objeto (LEONTIEV, 2001).

Em outro momento (grupo E), esta discussão sobre a fervura dos utensílios novos de alumínio também foi levantada e melhor desenvolvida. Outros alunos do mesmo grupo evidenciaram também a formação do óxido de alumínio enquanto "camada protetora". A postagem a seguir evidenciou a solubilidade do metal alumínio, e por isso achamos relevante produzi-la: 


\title{
Trecho 3 (Episódio 2)
}

\section{Re: Fórum de Discussão - Semana 13 - por aluno C3 - sexta, 23 Out 2015, 09:20}

(...) Por possuir trivalência positiva faz com que seja altamente oxidável, sua aparência visual é de cinza fosco, para que sua verdadeira aparência brilhante seja vista, é necessário um polimento ou atrito com outro metal mais duro. Porém não é recomendado arear aquela camada escura (óxido de alumínio) que se forma no fundo após a fervura de água, pois está camada reduz em até seis vezes a transferência do componente para a comida. Recomenda-se que sejam usadas em cozimentos rápidos, como frituras por imersão, e no preparo de alimentos secos, como farofa, uma vez que o contato prolongado com a água e com alimentos ácidos favorece a liberação do alumínio no alimento (...).

O pesquisador fez a seguinte intervenção, importante no sentido conceitual do referido óxido em meios ácidos e básicos:

\section{Re: Fórum de Discussão - Semana 13 - por pesquisador - domingo, 25 Out 2015,}

$\underline{16: 26}$

\section{Olá C3!}

Parabéns pela participação!

Você citou que "o contato prolongado com a água e com alimentos ácidos favorece a liberação do alumínio no alimento.

E no caso de alimentos básicos? Haveria algum problema?"

Essas mediações/intervenções do pesquisador por meio da palavra escrita, poderiam favorecer as operações em direção a formação do conceito.

Segundo Vigotski (2005, p. 72-73):

\begin{abstract}
A formação dos conceitos é resultado de uma complexa atividade em que todas as funções intelectuais fundamentais participam (...). Todas estas funções são indispensáveis, mas não são suficientes se não se empregar o signo ou a palavra, como meios pelos quais dirigimos as nossas operações mentais, controlamos o seu curso e o canalizamos para a solução do problema.
\end{abstract}

As postagens do pesquisador no referido fórum de discussão, caracterizada por questões orientadoras e (re)direcionadoras, poderiam ser consideradas o elo de ligação entre o objeto não material (construção do conceito de solubilidade dos metais) e os sujeitos envolvidos na $\mathrm{AE}$. 
Assim, o estudante C3 fez uma nova postagem, após o questionamento do pesquisador acerca da solubilidade do metal alumínio em meio básico:

\section{Trecho 4 (Episódio 2)}

Re: Fórum de Discussão - Semana 13 - por aluno C3 - sexta, 30 Out 2015, 11:02

Bom dia! Os alimentos básicos também teremos problema, ou seja, ocorrerá a contaminação, porém será seis vezes menor, conforme informação no site consultado.

O aluno C3, concluiu que o meio básico também seria importante na liberação do metal de acordo com a fonte consultada. Todavia foi necessária, mais uma vez a mediação do pesquisador sobre este conceito mais elaborado sobre solubilidades em meios diferentes (ácidos e básicos):

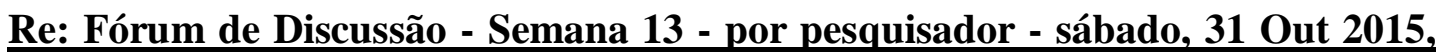

$\underline{09: 54}$

Olá C3!

Vale acrescentar que não só em meios ácidos, mas o óxido de alumínio também pode reagir (solubilizar) em meios básicos. Dizemos que é "anfótero". Ser "anfótero" é ter comportamento ambíguo.

Desta forma, fomos caminhando para a formulação conceitual do fenômeno apresentado na AE. Até aquele momento, sabíamos que o alumínio da panela: estaria na "forma química" metálica (liga metálica), poderia ser solubilizado na forma de óxido, em meios ácidos e básicos, que aumento da temperatura contribuiria para esta solubilização e que a prática de "aerar" as panelas não seria muito indicada, uma vez que favoreceria a liberação deste metal. Faltava ainda saber como esse metal seria liberado. Várias vezes o pesquisador fez esta pergunta, sem muito sucesso.

Em outros grupos, duas situações chamaram a atenção e serão reproduzidas a seguir. Uma em relação a um saber cotidiano acerca deste fenômeno e outra sobre a oxidação do alumínio (formação do óxido referido várias vezes como camada protetora):

\section{Trecho 5 (Episódio 2)}

Re: Fórum de Discussão - Semana 13 - por aluno D1 - quinta, 22 Out 2015,

\section{$\underline{21: 08}$}

Professor, a forma oxidada seria o Óxido de alumínio? $\mathrm{Al}_{2} \mathrm{O}_{3}$ ?

Lembrei-me de outras coisas a respeito do uso de Al. e alimentação, antigamente os espremedores de limão/laranja tinha peças em Al. As mesmas foram substituídas por plástico. Outro fato interessante em relação a alimentação é que quando vamos cozinhar ovo ou algo em banho-maria (uma forma com o que está sendo cozido dentro de uma assadeira contendo 
água), temos por hábito colocar junto a água da assadeira, limão ou vinagre para que o alumínio não fique "escuro" (oxidado), faz parte do conhecimento popular.

A postagem deste aluno foi importante, pelo fato de resgatar mais alguns conceitos espontâneos que foram desenvolvidos ao longo da história e que foram sendo reproduzidos pelas donas de casa.

Seguindo esta linha de raciocínio, os espremedores antigos de frutas ácidas não poderiam ser produzidos do material alumínio (solubilização do metal) e assim foram substituídos por espremedores de plásticos. No que diz respeito às assadeiras do referido metal, as donas de casa tinham o hábito de colocar limão ou vinagre (ácidos) quando estivessem produzindo o "banho-maria", para que a assadeira não ficasse escura. Cientificamente, o escurecimento estaria vinculado a produção do óxido de alumínio e o clareamento, vinculado a dissolução desta camada.

Esta postagem vem ao encontro de outra em que foi apresentada a necessidade de ferver os utensílios novos de alumínio com água (saber espontâneo), antes de utilizá-los. Ou seja, esta fervura contribuiria para a formação da tal camada protetora na forma de óxido.

\section{Re: Fórum de Discussão - Semana 13 - por aluno E1 - quarta, 21 Out 2015,} $\underline{18: 49}$

As panelas de alumínio são constituídas de alumínio metálico, ou seja, $A l^{0}$. Quando cozinhamos nela, não raramente vemos seu escurecimento. Isso se deve à oxidação do alumínio metálico, que cede elétrons em reações químicas (com os íons presentes na água que ferveu na panela, por exemplo), associando-se ao oxigênio, formando assim o óxido de alumínio $\left(\mathrm{Al}_{2} \mathrm{O}_{3}\right)$.

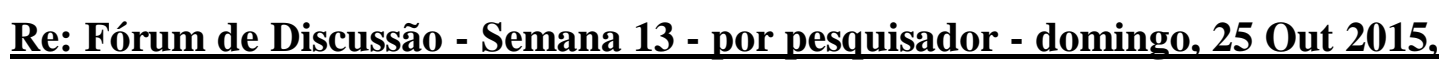
$\underline{15: 50}$

Olá E1!

Parabéns pela participação!

Você citou a formação da camada de óxido, muito bom! E seria esta a "forma química" do alumínio que é liberado (solubilizado)?

\section{Re: Fórum de Discussão - Semana 13 - por aluno E1 - terca, 27 Out 2015, 15:32}

Eu acredito que não, já que o óxido de alumínio é insolúvel em água. Por isso não é muito bom utilizar essas panelas ao cozinhar alguma coisa ácida, como o molho de tomate, já que o óxido é insolúvel em água, mas se torna um reagente em meios ácidos. 
Assim, para finalizar seria necessário esclarecer se esta camada de óxido de alumínio formada seria boa ou ruim para nós, utilizadores dos utensílios metálicos em questão.

\section{Trecho 6 (Episódio 2)}

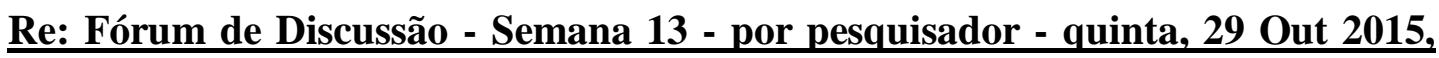

$\underline{10: 15}$

(...) E então, o que podemos concluir?

Alguém mais gostaria de contribuir?

Re: Fórum de Discussão - Semana 13 - por aluno E2 - quinta, 22 Out 2015, $\underline{16: 50}$

(...) Quando a Panela de Alumínio é aquecida, o metal se oxida, liberando Alumina $\left(\mathrm{Al}_{2} \mathrm{O}_{3}\right)$, tanto interna quanto externamente, com o tempo as partículas vão se acumulando e tornando a superfície preta. Bem, a remoção da parte escurecida é um mero reflexo de limpeza da dona de casa, porém quando isso é feito a superfície fica pronta novamente para outro processo de oxidação e com uma superfície mais polida(areada)aumentará ainda mais o desprendimento de Alumínio, de fato a oxidação vai ocorrer sempre,assim como a liberação de Alumínio, o ideal neste caso é apenas polir a parte externa da panela.

Entendemos que neste momento, uma relação entre a fervura dos utensílios novos de alumínio e a formação da camada de óxido tenho sido estabelecida. Uma observação importante para esta constatação, à luz da "Teoria da Atividade", seria a "transformação do motivo" da atividade.

Vimos que nas discussões iniciais, os motivos para a realização da atividade de ensino seriam apenas "motivos eficazes", ou seja, obtenção da resposta da questão, nota na disciplina entre outros. Todavia, quando o grupo deu sequência às discussões, um motivo até então "compreensível" (construção do conceito) poderia também ser estabelecido como eficaz.

Vejamos o seguinte exemplo acerca da possibilidade de mudança de motivo: Uma criança não consegue dar seguimento aos seus estudos e aprendizados junto as atividades escolares. Sempre ouve seus pais dizerem que o estudo é importante para o futuro, para a formação enquanto cidadão, mas este motivo é apenas compreensível para a criança. Desta forma, foi proibida de sair para brincar até que as lições fossem realizadas (motivo eficaz). A criança inicia a atividade pensando em ser liberada para as brincadeiras. Porém, com o passar do tempo, na convivência com seus pares dentro e fora da Escola, começou a desenvolver os 
exercícios por iniciativa própria, sem a vinculação de alguma condição. Assim, o motivo agora eficaz era um motivo compreensível anteriormente (LEONTIEV, 2001).

Aos poucos, os conceitos científicos relativos ao fenômeno de cozinhar com panelas e utensílios de alumínio foram sendo constituídos (transformação de motivo). Porém, em todos os grupos foi observada a limitação de interação dos alunos entre si. Em alguns momentos o pesquisador fazia referência a mais de um aluno em uma única postagem, com o intuito de proporcionar uma maior interação entre eles:

\section{Trecho 7 (Episódio 2)}

Re: Fórum de Discussão - Semana 13 - por pesquisador - segunda, 26 Out 2015,

\section{$\underline{20: 25}$}

Olá H3 e H4!

Parabéns pela participação.

Vocês disseram que nas panelas temos ligas metálicas.

O H3 citou que este alumínio poderia ser liberado (solubilizado) em presença de água e sal de cozinha em altas temperaturas.

H3 poderia postar alguma reação química desta "solubilização do metal" em presença de água e sal?

A H4 citou inclusive quais os metais fazem parte desta liga e disse que "quando os utensílios são novos há uma maior migração de alumínio no ponto de ebulição" (...)

H4, pode ser mais específico? Ponto de ebulição de quem, da água?

Todavia, as postagens eram lidas e as respostas continuavam direcionadas para o professor/pesquisador.

A referência dos alunos para com eles mesmos foi sempre generalizada e apenas na saudação da postagem, tais como: "Olá professor e colegas", "boa noite professor e colegas" e assim por diante.

Assim, entendemos que apesar de a natureza social de interação ter sido limitada nesta $\mathrm{AE}-\mathrm{EaD}$, as questões e conceitos espontâneos trazidos foram expressivos. Após o encerramento da data de entrega da questão avaliativa e também da data limite para a participação no fórum de discussão, o pesquisador fez uma postagem geral acerca dos temas discutidos para que os alunos pudessem se apropriar uma pouco mais dos conceitos envolvidos. Achamos importante reproduzir esta postagem a seguir, uma vez que este trabalho também foi direcionado ao grupo de cientistas da natureza: 


\section{Trecho 8 (Episódio 2)}

\section{Re: Fórum de Discussão - Semana 13 - por pesquisador - quinta, 5 Nov 2015,}

$\underline{22: 39}$

Olá pessoal!

Parabéns pela discussão desenvolvida neste fórum!

Abaixo, um feedback geral sobre o conteúdo abordado:

Independentemente de o metal alumínio ser nocivo a saúde do homem ou não, o tema proposto permeava o conteúdo "solubilidade".

Insistimos algumas vezes na discussão da "forma química" de cada elemento, que estaria ligada a solubilidade.

Por exemplo: O mercúrio (Hg) é considerado um metal pesado. Porém "a forma" que propicia a sua assimilação (bioacumulação e biomagnificação) pelos organismos vivos é a do cátion metil mercúrio $\left(\mathrm{CH}_{3}-\mathrm{Hg}^{+}\right)$.

Por outro lado, temos também o exemplo dos garimpos, onde os vapores de mercúrio podem ser inalados atingindo pulmões, corrente sanguínea e etc.

Assim, é necessário pensar sempre na forma, no estado físico, na solubilidade e no meio em que o elemento está disponível.

O alumínio das panelas está na forma metálica $\left(A l^{0}\right)$. Poderá ser liberado devido ao processo de solubilização do metal. A forma liberada é de "íon solúvel” ( $\left.\mathrm{Al}^{3+}\right)$.

Por ser reativo, o alumínio reage com o oxigênio do ar formando o óxido de alumínio, $\mathrm{Al}^{2} \mathrm{O}_{3}$, que é pouco reativo.

Assim, forma-se sobre o alumínio uma película protetora deste óxido que o protege: $2 \mathrm{Al}^{3+}+3 / 2 \mathrm{O}_{2}-\rightarrow \mathrm{Al}_{2} \mathrm{O}_{3}$ (reação de formação do óxido). O óxido é insolúvel em água.

Atritar a palha de aço ou outro material com a superfície metálica contribui para a remoção da camada de óxido de alumínio.

O cozimento de substâncias ácidas, como o extrato de tomate, doces em calda e etc. levariam a uma parcial dissolução da camada protetora: $\mathrm{Al}_{2} \mathrm{O}_{3}+6 \mathrm{H}^{+} \rightarrow 2 \mathrm{Al}^{3+}+3 \mathrm{H}_{2} \mathrm{O}$ (reação de dissolução do óxido). Vale acrescentar que não só em meios ácidos, mas o óxido de alumínio também pode reagir (solubilizar) em meios básicos. Dizemos que é "anfótero".

OBS: Na prática o processo é um pouco diferente. O alumínio é um bom agente redutor, ou seja, oxida com facilidade $\left(A l^{0} \grave{a} A l^{3+}\right)$. O íon $A l^{3+}$ reage com a água, originando o hidróxido de alumínio. O hidróxido (com aquecimento) origina o óxido de alumínio.

Obrigado a todos! Qualquer dúvida, por favor escrevam! 


\section{CONCLUSÕES}

A organização de uma $\mathrm{AE}$ para a $\mathrm{EaD}$ trouxe algumas particularidades, uma vez que as interações foram diferentes em relação a uma situação presencial. Ao planejar a AE-EaD, concentramos em não valorizar situações práticas experimentais, pois nesta situação virtual, o aluno estaria "sozinho" durante o desenvolvimento da atividade e sem muitos recursos laboratoriais.

Apesar de o planejamento da AE-EaD não ter sido tão diferente do planejamento da AOE-Presencial, podemos notar que a interação aluno-aluno ficou prejudicada na atividade a distância. De forma geral, na $\mathrm{EaD}$, os participantes discutiam as questões com o pesquisador/mediador e a interação aluno-aluno foi mínima.

No ensino presencial a aplicação da AOE teria sido analisada em maior parte do ponto de vista de cada indivíduo e acreditamos que esta caracterização tenha sido mantida na $\mathrm{AE}$ desenvolvida na EaD. Todavia, as informações ou experiências cotidianas se mostraram mais evidentes no formato $\mathrm{AE}-\mathrm{EaD}$ em detrimento da AOE-Presencial. Talvez pelo fato de nesta primeira, os alunos possuírem um tempo maior para reflexão e busca, não sendo necessário formular "respostas imediatamente" como em uma aula presencial.

As referidas experiências cotidianas levantadas pelos alunos foram nevrálgicas junto a movimentação entre os conceitos espontâneos e científicos. Entendemos que a mediação durante o desenvolvimento da $\mathrm{AE}$ favoreceu o surgimento destes exemplos, que foram debatidos e passíveis de generalização. Em um curso a distância onde a maioria dos alunos estuda "sozinha", a mediação tem um papel crucial junto a ruptura deste isolamento. A Internet permite o acesso rápido a milhares de informações sobre determinado assunto e o gerenciamento e a mediação destas informações são de suma importância para uma sistematização em direção ao conhecimento.

Em todas as AEs, as intervenções do pesquisador foram constantes. Estas intervenções apresentariam caráter de aprendizagem mediada, onde a seleção, reflexão, modificação e significação do objeto é requerida. A referida mediação foi mais evidente por parte do pesquisador, e menos pronunciada por parte dos alunos. Mas o complexo fenômeno da aprendizagem mediada envolve o meio, todos os sujeitos (alunos e professores), a ferramenta, e outros recursos possíveis. Em nosso entendimento, essa aprendizagem mediada seria possível se a interação entre sujeito, objeto, símbolos e meio, fosse estabelecida. De outra forma, impossibilitaria a movimentação dos conceitos, mesmo que o espaço 
disponibilizado tenha sido elaborado com ferramentas para ser considerado um local de aprendizagem.

Havia um histórico insatisfatório de participação dos alunos junto aos fóruns de discussão onde as AEs foram inseridas. Assim, foi necessário vincular conceitualmente o referido fórum a uma questão avaliativa a ser entregue. Esta prática favoreceu o aumento do número de postagens na plataforma. Porém, inicialmente os alunos buscavam a resposta pronta da referida questão, ou seja, o motivo inicial não coincidia com o objeto. Assim, foi necessário instigar os participantes, de forma a "responder" as suas dúvidas com novos questionamentos, reflexivos e direcionadores.

Nos 8 grupos em que a $\mathrm{AE}$ foi desenvolvida, alguns conceitos foram estabelecidos, outros foram questionados e refutados. Houve determinada generalização na AE-1, acerca dos conceitos de misturas, forma química dos metais presentes nos batons e brilhos labiais e solubilidade destes, no sentido de remoção após a aplicação.

No caso da AE-2, discussões acerca de evidências de reações químicas, fatores que influenciam nas velocidades destas reações como temperatura, pressão e umidade foram levantados. Exemplos do cotidiano como o trabalho de amigos e as próprias experiências práticas e sensoriais dos alunos foram apresentadas.

Já na AE-3, houve dificuldades por parte dos alunos no que diz respeito a interpretação da questão sobre a forma química do alumínio presente nas panelas. Alguns trouxeram respostas acerca do número de massa, número de elétrons em outras especificidades do elemento. Durante o desenvolvimento do fórum, a contribuição de outros colegas, mediada pelo pesquisador, favoreceu a discussão acerca do estado de oxidação do metal e a influência deste junto a sua solubilidade. Foi consenso a postagem sobre existência de uma camada protetora de óxido de alumínio nestes utensílios. Porém, a discussão foi importante para elucidar como seria formada esta camada e quais os seus possíveis benefícios e limitações.

No caso da AE-3, além da reflexão sobre a forma química do alumínio e do seu estado físico, surgiram informações acerca da solubilidade ser influenciada pelo meio em que o elemento está disponível (cozimento de molho de tomate, doces em calda e etc.). Também foi evidenciado que a prática de arear as panelas contribuiria para a liberação do metal, independentemente se a quantidade liberada poderia ser prejudicial a saúde ou não.

Em termos de considerações acerca do objetivo geral desta pesquisa, destacamos que a atuação pedagógica do professor mediador (tutor) teve grande importância na motivação dos alunos, na identificação de conceitos químicos relativos aos exemplos citados e na proposição 
do engajamento dos alunos nas atividades. A proposta teórico-metodológica adotada, AE, foi a base para uma estratégia de ensino direcionada e intencional e isso qualifica que, com base nos referenciais teóricos adotados, foi possível reconhecer a importância do aluno, do professor, do motivo e do conhecimento como vértices de um sistema de aprendizagem que é amplo, complexo, mas que guarda importantes aspectos relativos às novas formas de relações de ensino e de produção de conhecimento científico escolar.

\section{REFERÊNCIAS}

BRANDÃO, C. R.; BORGES, M. C. A pesquisa participante: um momento de educação popular. Revista Educação Popular, p. 51-62, 2007.

BRANDÃO, C. R.; Streck, D. R. (Orgs). Pesquisa participante: a partilha do saber. 3.ed. Aparecida: Ideias \& Letras, 2006. 295p.

Brasil. Decreto $\mathrm{n}^{\circ}$ 5.622, de 19 de dezembro de 2005. Regulamenta o Artigo 80 da Lei 9.394, de 20 de dezembro de 1996, que estabelece as Diretrizes e Bases da Educação Nacional. Diário Oficial da União. Brasília.

BOGDAN, R. C.; BIKLEN, S. K. Investigação qualitativa em educação. Tradução Maria João Alvarez, Sara Bahia dos Santos e Telmo Mourinho Baptista. Porto: Porto Editora, 1994.

DEWEY,J.; BENTLEY,A.F.Knowing and the Known, Boston: Beacon Press, 1949.

ENGESTRÖM, Y. Activity theory and individual and social transformation. In: MIETTINEM, R.; PUNAMÄKI, R. Perspectives on Activity Theory. Cambridge, Cambridge University Press 1999.cap.1, p.1-16.

.Expansive learning at work: to ward an activity theoreticalreconceptualization. Journal of Education and Work, v. 14, n.1, 200 p. 133-156, 2001.

Espimpolo, D. M., Iamamoto, Y., e Abreu, D. G. Atividade Orientadora de Ensino e a apreensão de conhecimentos em Química. Revista Brasileira de Pesquisa em Educação em Ciências, 105-129, 2012.

GÓES, M. C. R. de. A abordagem microgenética na matrizhistórico-cultural: Uma perspectiva para oestudo da constituição da subjetividade.Cadernos Cedes, ano XX, no 50, p. 9-25, 2000.

KOZULIN, A.; PRESSEISEN, B. Z. Mediated Learning Experience and Psychological Tools: Vygotsby's and Feuerstein's Perspectives in a Study of Student Learning. Educational Psychologist, p. 67-75, 1995.

KRASILCHIK, Myriam. Reformas e Realidade: o caso do ensino de Ciências. São Paulo em Perspectiva, v. 14, n. 1, p. 85-93, 2000.

LEONTIEV, A. N. O desenvolvimento do psiquismo.Lisboa: Livros Horizontes LDA, 1978. 
Uma contribuição à teoria do desenvolvimento da psique infantil. In VIGOTSKI, L. S.; Luria, A. R. \& Leontiev, A. N., Linguagem, desenvolvimento e aprendizagem.São Paulo: Ícone. Tradução Maria da Pena Villalobos. 2017, p. 59 - 83.

LEVY, Pierre. Cibercultura. 7. reimpressão. São Paulo: Editora 34, 2008.

LIBÂNEO, J. C., e Pimenta, S. G. Formação de profissionais da educação: visão crítica e perspectiva de mudança. Educação \& Sociedade, p. 239-277, 1999.

LURIA, A. R. Fundamentos de Neuropsicologia. Rio de Janeiro: Livros Técnicos e Científicos; São Paulo: Ed. da Universidade de São Paulo, 198Í.

MAIA, C.; MATTAR, J. ABC da EaD: a educação a distância hoje. São Paulo: Pearson, 2007.

MATTAR, J. Guia de Educação a Distância. São Paulo: Cengage Learning, 2011.

MARTINS, O. B.; MOSER, A. Conceito de mediação em Vigotski, Leontiev e Wertsch. Revista Intersaberes, vol. 7 n.13, p. 8 - 28, 2012.

MARX, K.; ENGELS, F. A ideologia alemã (Feuerbach). 9. ed. SãoPaulo: HUCITEC, 1993.

MILGRAM, P. et. al. Augmented Reality: A Class of Displays on the Reality-Virtuality Continuum. Telemanipulator and Telepresence Technologies, SPIE, v. 2351, p. 282-292, 1994.

MOORE, M.; KEARSLEY, G. A educação a distância: uma visão integrada. Trad. Roberto Galman. São Paulo: Thomson Learning, 2007.

MOORE, M. G. Teoria da distância transacional. Revista Brasileira de Aprendizagem Aberta e a Distância, São Paulo, Agosto 2002. Publicado originalmente em KEEGAN, D. Theoretical principles of distance education. London: Routledge, 1993. p. 22-38. Traduzido por Wilson Azevêdo, com autorização do autor.

MORETTI, V. D. Professores de matemática em atividade de ensino. Uma perspectiva histórico-cultural para a formação docente. Tese (Doutorado em Educação) - Faculdade de Educação, Universidade de São Paulo, São Paulo, 2007.

MOURA, M. O. O Jogo e a Construção do Conhecimento Matemático. Publicação séries e ideias, p. 45-52, São Paulo, 1992.

MOURA, M. O., et al. Atividade orientadora de ensino: unidade entre ensino e aprendizagem. Revista Diálogo Educacional, p. 205-229, Curitiba, 2010.

NARDI, R.; ALMEIDA, M. J. P. M. Formação da área de ensino de ciências: memórias de pesquisadores no Brasil. Revista Brasileira de Pesquisa em Educação em Ciências, Porto Alegre, v. 4, n. 11, p. 90-100, 2004.

Investigações em ensino de ciências no Brasil segundo pesquisadores da área: alguns fatores que lhe deram origem. Pro-Posições, Campinas, v. 18, n. 1, p. 213-226, jan./abr. 2007. 
NUNEZ, I. B. Galperin, Leontiev e Vygotsky. Formação de conceitos e princípios didáticos. Brasília: Líber Livro, 2009.

OSAKABE, H. O mundo d escrita. In: ABREU, M. (org.) Leituras do Brasil.Campinas-SP. Mercado das Letras, 1995, p. 15-22.

PÊCHEUX, G.; GADET, F. A língua inatingível. In: ORLANDI, E. P. Análise de Discurso: Michel Pêcheux. Campinas-SP: Pontes, 2011.

PÊCHEUX, M. Papel da memória. In: ACHARD, P. [et al] Papel da memória.Campinas-SP: Pontes, p. 49-57, 2007.

POH, M.Z.; SWENSON, N.C.; PICARD, R.W. A Wearable Sensor for Unobtrusive, Longterm Assessment of Electrodermal Activity. Ieee Transactions on Biomedical Engineering, vol. 57, no. 5, 2010.

SANCHEZ, J. R. A atividade orientadora de ensino como alternativa metodológica para a abordagem de metais pesados na disciplina de Química Analítica Qualitativa. 2014. Dissertação (Mestrado em Química) - Faculdade de Filosofia, Ciências e Letras de Ribeirão Preto, Universidade de São Paulo, Ribeirão Preto, 2014.

SILVA, E.T. Leitura ou lei-dura? In: ABREU, M. (org.) Leituras do Brasil. CampinasSP. Mercado das Letras, p. 23-28, 1995.

TIKHOMIROV, O. K. The theory of activity changed by information technology. In: ENGESTRÖM, Y.; MIETTINEM, R.; PUNAMÄKI, R. Perspectives on Activity Theory. Cambridge, Cambridge University Press 1999.cap.21, p.347-359.

TORI, R. Educação sem distancia: as tecnologias interativas na redução de distancias em ensino aprendizagem. São Paulo: editora SENAC São Paulo,2010.

TORI, R.; KIRNER, C.; SISCOUTTO, R. Fundamentos e Tecnologia de Realidade Virtual e Aumentada. Belém - PA: SBC - Sociedade Brasileira de Computação, Porto Alegre, 2006.

VIGOTSKI, L. S. A formação social da mente. São Paulo: Martins Fontes, 1998.

Pensamento e linguagem.São Paulo: Martins Fontes, 2001.

WERTSCH, J. V.Vygotsky and the social formation of mind. Harvard University Press 
6. ANEXOS 
AOE - Metais Pesados (Mestrado)

Disponível em: <http://g1.globo.com/bemestar/noticia/2013/05/estudo-dos-euaalerta-para-indices-de-metais-em-batons-e-brilhos-labiais.html>. Acesso em 10 de maio de 2013.

\section{Estudo dos EUA alerta para índices de metais em batons e brilhos labiais}

Pesquisa encontrou chumbo, cádmio e cromo em cosméticos analisados. Alguns componentes químicos estão relacionados a doenças como câncer.

Pesquisadores da Universidade da Califórnia, nos Estados Unidos, analisaram 32 tipos diferentes de batons e brilhos labiais e detectaram a presença de metais como chumbo, cádmio, cromo e alumínio em pequenas e grandes quantidades nesses produtos. O fato preocupa pois alguns desses componentes químicos constantemente são relacionados a doenças graves como o câncer.

O estudo, divulgado nesta quinta-feira (2) na revista "Environmental Health Perspectives", aponta a necessidade de maior regulamentação desses cosméticos no país, já que nos Estados Unidos não há uma lei específica sobre metais em cosméticos.

Foram analisados 8 batons e 24 brilhos labiais de 7 diferentes empresas. Os preços dos produtos variavam de US\$ 5,59 a US\$ 24 e eram os mais usados por jovens, de acordo com estatística obtida pelos investigadores.

Segundo o estudo, em dez amostras das 32 analisadas, foram encontrados níveis de cromo acima do tolerável, se considerada a média diária de ingestão involuntária. Além disso, em 24 produtos havia presença de chumbo. Apesar do nível não ser considerado alarmante, sua presença preocupa devido à possível exposição a crianças.

\section{Ingestão involuntária}

Os cientistas analisaram ainda o impacto da ingestão involuntária da maquiagem. Uma pessoa comum ingere em média 24 miligramas por dia de batom ou gloss (que vai para o estômago com a saliva). Em casos de uso excessivo, a ingestão pode chegar a 87 miligramas.

De acordo com os pesquisadores, a ingestão de maquiagem com metais oferece riscos à saúde. A exposição excessiva ao cromo, por exemplo, preocupa porque a substância é cancerígena e normalmente está relacionada a tumores no estômago.

A presença de manganês nesses produtos pode também oferecer risco, já que o metal pode causar danos ao sistema nervoso. 
Os cientistas disseram que não há nenhuma razão para lançar tais produtos no lixo após os resultados. No entanto, a quantidade de metais encontrada sinaliza a necessidade de aumentar a fiscalização desses produtos por órgãos regulares de saúde.

A pesquisa aponta ainda que não existem normas americanas para metais em cosméticos. No entanto, ressaltam que a União Europeia considera o cádmio, cromo e chumbo ingredientes inaceitáveis, em quaisquer níveis, em produtos cosméticos.

\section{Atividade Orientadora:}

Imagine que você é o químico contratado pela empresa que investiga o fato descrito na notícia. Uma empresa televisiva lhe convidou para dar uma entrevista explicando para população do ponto de vista científico qual é o problema com os metais pesados. O jornalista adiantou que a população quer saber o que é um metal pesado, o que sua ingestão pode causar para saúde humana, quais concentrações são toleráveis e etc. Desta forma, você deverá elaborar um texto breve com esta finalidade.

Um químico, após tratamento adequado e isolamento dos íons metálicos de vários lotes de amostras dos cosméticos sob suspeita (batons), deixou no laboratório um béquer com o resíduo obtido. Suponha que tal solução gerada na análise possa conter altas concentrações dos metais citados na notícia.

Para decidir que destino dar a este resíduo, caberá a você propor uma rota para separar e identificar os possíveis metais. No $2^{\circ}$ encontro será realizada a análise da solução fictícia de batons e emissão do parecer sobre a composição e destinação final dos metais presentes. 


\section{TERMO DE CONSENTIMENTO LIVRE E ESCLARECIDO}

Eu abaixo assinado, declaro consentir participar como voluntário (a) do projeto de pesquisa "Aprendizagem de conceitos químicos num curso EaD: contribuições da Teoria da Atividade", desenvolvido pelo aluno João Ricardo Sanchez, pós-graduando do Departamento de Química, da Faculdade de Filosofia, Ciências e Letras de Ribeirão Preto (DQ/FFCLRP/USP), sob orientação da Profa. Dra, Daniela Gonçalves de Abreu Favacho.

Declaro conhecer a justificativa, os objetivos e os procedimentos que serão utilizados na pesquisa. Também declaro ter ciência que a participação na referida pesquisa não acarretará nenhum dano pessoal para mim e ainda poderá contribuir para a melhoria do ensino. Tenho ciência que posso desistir de participar do projeto a qualquer momento, sem nenhum prejuízo para mim. Autorizo que os registros relativos a entrevistas e diálogos sejam utilizados dentro dos princípios éticos e quando divulgados em artigos científicos ou mesmo em comunicações em congressos, deve-se resguardar o sigilo quanto à minha identidade.

Nome do participante (por extenso)/ assinatura/e-mail-telefone

Aluno/Pesquisador: João Ricardo Sanchez

AV. BANDEIRANTES, 3900, CEP 14040901

MONTE ALEGRE, RIBEIRÃO PRETO

e-mail:

telefone:

Orientador: Daniela Gonçalves de Abreu Favacho

e-mail:

telefone: 